\title{
TURONIAN-CAMPANIAN STRATA EAST OF THE TRANS-ALASKA PIPELINE CORRIDOR, NORTH SLOPE FOOTHILLS, ALASKA: PROGRESS DURING THE 2001-02 AND 2007 FIELD SEASONS
}

\author{
by \\ David L. LePain ${ }^{1}$, Russell Kirkham², Robert Gillis', and Jacob Mongrain ${ }^{3}$
}

\begin{abstract}
Lower Turonian through Campanian strata are discontinuously exposed along an unnamed drainage approximately $6 \mathrm{~km}$ east of the Sagavanirktok River, in the Sagavanirktok Quadrangle, in the foothills north of the Brooks Range. In spite of some outcrop-scale deformation, this succession is viewed as a relatively continuous and unbroken succession deposited basinward (east and north) of the terminal Nanushuk shelf edge. South-dipping exposures of sandstone, siltstone, and tuff are separated by long tundra-covered intervals inferred to be underlain by finer-grained lithologies. Field studies by DGGS in 2001, 2002, and 2007 document the depositional setting of this succession and provide a framework for more detailed facies analysis and bedrock geological mapping in the area.

Lower Turonian strata at the northwest end of the succession consist dominantly of shale with 18-30m-thick packages of interbedded mudstone and sandstone recording deposition as sandstone lobes in basin floor settings. This part of the succession is tentatively correlated with Seabee Formation west of the TransAlaska pipeline corridor. Santonian to lower Campanian strata in the middle of the succession also consist dominantly of shaly lithologies interrupted by 25-60-m-thick packages of interbedded mudstone, sandstone, minor conglomerate, and silicified tuff deposited as sandstone lobes and overbank deposits (levees) and submarine ashfalls in proximal basin to lower slope settings. Campanian strata near the south end of the trend includes interbedded siltstone and sandstone deposited in slope and outer-shelf settings, below storm wave-base. Campanian strata at the southeast end of the trend consists of siltstone and sandstone in a series of stacked offshore-shoreface parasequences. Collectively, these rocks record the eastward progradation of Upper Cretaceous basin floor-slope-shelf depositional systems beyond the terminal Nanushuk (Cenomanian) shelf edge. A composite thickness of 2,460 m is estimated for this Upper Cretaceous succession.
\end{abstract}

\section{INTRODUCTION}

During the summers of 2001 and 2002 the Alaska Division of Geological \& Geophysical Surveys (DGGS) conducted detailed stratigraphic investigations of upper Cretaceous strata exposed along an unnamed drainage between the Sagavanirktok and Ivishak rivers, in Township 3 South, Range 15 East, sections 17, 20, 21, 27, and 28, Sagavanirktok A-3 Quadrangle (figs. 1-3). By virtue of its position between two named rivers, this drainage has been informally referred to as Sagashak Creek. DGGS revisited many of these exposures during the 2007 field season to refine interpretations of the depositional setting and to clarify correlations with coeval shelf strata exposed west of the Trans-Alaska pipeline corridor. Available unpublished geological mapping and biostratigraphic data suggest a relatively unbroken south-dipping succession of lower Turonian to Campanian age strata on the south flank of the Aufeis anticline (fig. 4; Mull, unpublished data). Publicly available seismic data indicate this succession is situated basinward of the terminal Cenomanian Nanushuk shelf edge (Houseknecht and Schenk, 2001; 2004). The uniqueness of this long, discontinuous section necessitates that the following discussion include our station-by-station observations on the facies and sedimentology of each outcrop. We hope that this level of documentation will allow interested workers to locate and revisit specific parts of the section. In the near future, DGGS intends to synthesize available surface and subsurface data to arrive at an integrated picture of the Upper Cretaceous stratigraphic evolution.

Many exposures along this trend include examples of small-scale folding and thrust faulting, and one exposure includes complex disharmonic folds in a thinly interbedded succession of shale, sandstone, and tuff. These complications, combined with long tundra-covered intervals, precluded measurement of a single continuous stratigraphic section. Instead, our approach was to measure detailed sections where exposure quality permitted, obtain general descriptions for rubbly exposures unsuitable for measuring, obtain relatively accurate geographic coordinates for the base and top of each measured section and the central point of each rubblecrop using a handheld global positional unit, and to reconstruct the larger succession from the resulting dataset. Using this approach we calculated

${ }^{1}$ Alaska Division of Geological \& Geophysical Surveys, 3354 College Rd., Fairbanks, Alaska 99709-3707

Email for David L. LePain: dave.lepain@alaska.gov

${ }^{2}$ Alaska Division of Mining, Land \& Water, 550 W. 7th Ave., Suite 900D, Anchorage, Alaska 99501-3577

${ }^{3}$ University of Alaska, Department of Geology \& Geophysics, P.O. Box 757320, Fairbanks, Alaska 99775-7320 


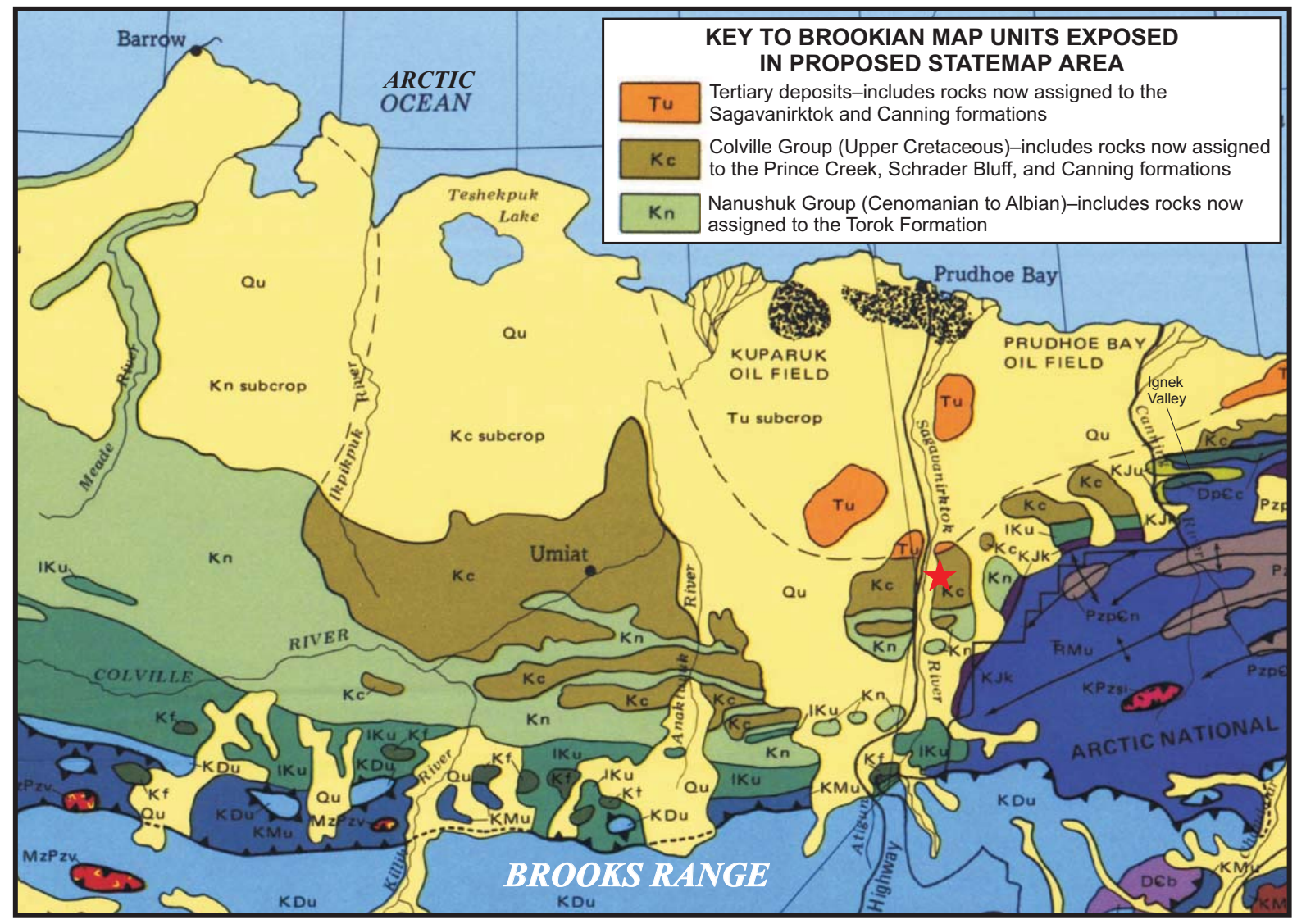

Figure 1. Generalized geologic map of the central North Slope. The red star shows the approximate location of the upper Cretaceous succession addressed in this report. The succession is located along the northeast side of an unnamed tributary drainage to the Sagavanirktok River. The southeastern end of this drainage is located midway between the Sagavanirktok and Ivishak rivers, which led to the informal name of Sagashak Creek. Map modified from Mull and Harris (1989).

a total stratigraphic thickness (station 045 to station 022; fig. 2) of 2,450 m. Given the potential errors inherent in our methodology, and uncertainty associated with structural complications, this estimate should be viewed only as a rough approximation of the true stratigraphic thickness of lower Turonian-Campanian strata in the area.

In the following section we present descriptions and interpretations of all major and most minor exposures along this trend. Figure 4 shows the locations of stations reexamined during the 2007 field season; the two southernmost stations shown on fig. 2 were not revisited. Latitude and longitude information is shown in table 1 . The degree of bioturbation is classified using Droser and Bottjer's (1986) ichnofabric index. The ichnofabric index is defined as follows: II1—unbioturbated; II2—up to 10 percent of original bedding disturbed; II3—approximately 10-40 percent of original bedding disturbed, burrows are typically isolated; II4—approximately 40-60 percent of bedding is disturbed, but last remnants are visible; II5—-bedding is completely disturbed, but discrete burrows are recognizable; II6-bedding nearly or completely homogenized. Outcrop gamma logs were acquired at selected exposures along this transect during 2007 using an Exploranium GR-320 enviSPEC gamma ray spectrometer. Gamma logs (total counts) are presented on the left side of the measured sections shown in this report (figs. 5, 7, 9, and 13).

\section{STATION DESCRIPTIONS AND INTERPRETATIONS}

\section{Station 07DL045 (01DL11)}

\section{DESCRIPTION}

Station 045 is located at the northwest end of the transect and consists of $23 \mathrm{~m}$ of interbedded sandstone, mudstone (argillaceous siltstone and siltstone), and minor clay shale (figs. 2, 4, and 5). Bedding dips 58 degrees toward the south-southeast. Tundra cover immediately north of the exposure suggests underlying strata consist of recessive-weathering mudstone and shale. At least one outcrop-scale syncline is present at the south end of the 


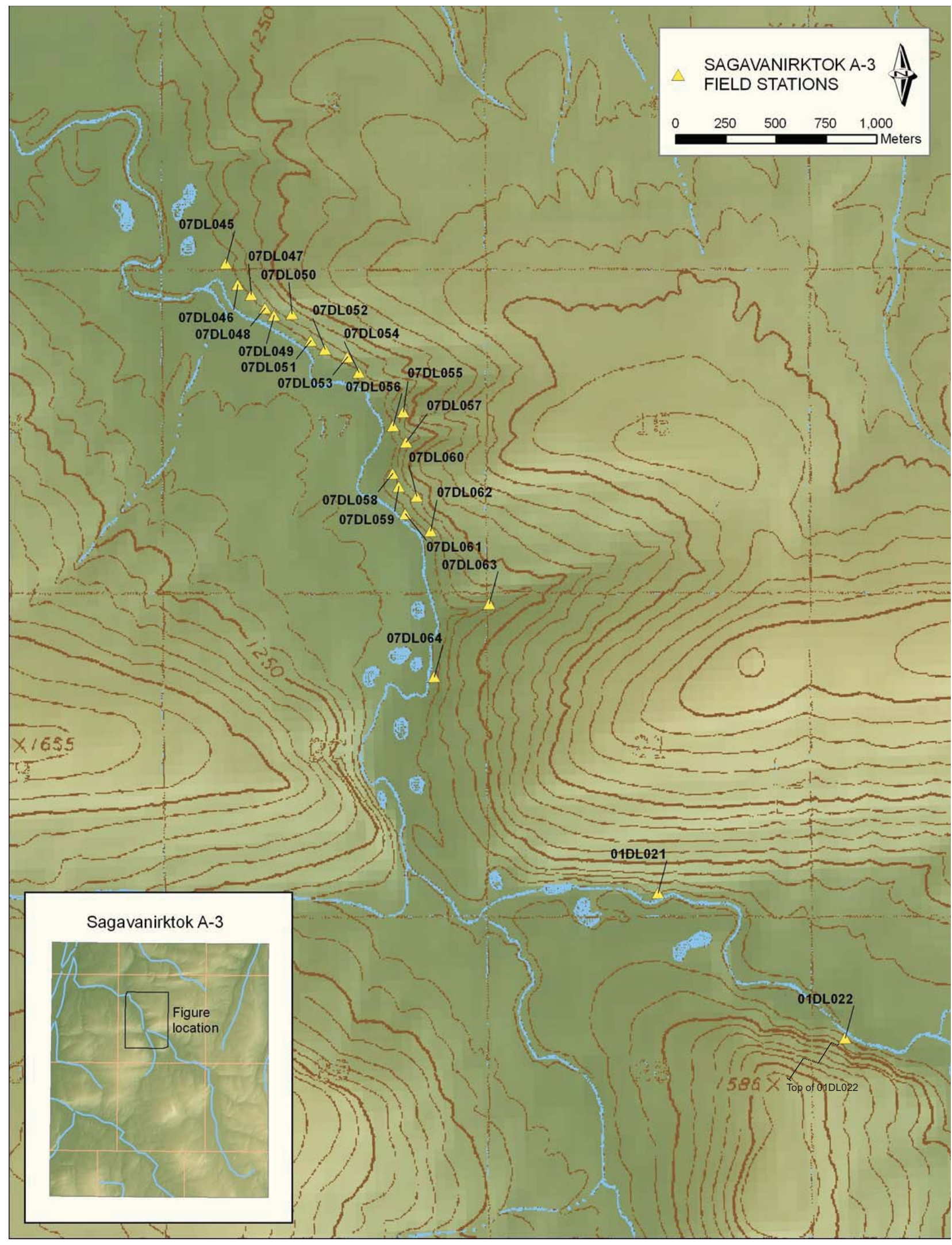

Figure 2. The portion of the Sagavanirktok A-3 1:63,360-scale topographic map that Sagashak Creek and the exposures of upper Cretaceous strata addressed in this report. Outcrop and rubblecrop are designated by station numbers that include the year (07 or 01), geologist's initials (DL), and a sequential number. The northwest end of this trend corresponds to station 07DL045, which is located at the base of a relatively coherent southeast- to south-dipping succession of deep-water through shoreface deposits. The succession ranges in age from Turonian at the northwest end to late Campanian at the southeast end. 
Table 1. Table summarizing station locations, available biostratigraphic control, and formation assignments

\begin{tabular}{|c|c|c|c|c|c|}
\hline Station & Latitude & Longitude & Age & $\begin{array}{l}\text { Formation } \\
\text { Assignment }\end{array}$ & Comments \\
\hline 07DL045 & 69.18997 & 148.56877 & Turonian-Coniacian $^{1}$ & Seabee & $\begin{array}{l}\text { Probably early Turonian; } \\
\text { sample collected at this station }\end{array}$ \\
\hline 07DL046 & 69.18902 & 148.56728 & early Turonian & Seabee & $\begin{array}{l}\text { Age assigned by relative } \\
\text { stratigraphic position }\end{array}$ \\
\hline 07DL047 & 69.18856 & 148.5656 & early Turonian & Seabee & $\begin{array}{l}\text { Age assigned by relative } \\
\text { stratigraphic position }\end{array}$ \\
\hline 07DL048 & 69.18797 & 148.56387 & early Turonian & Seabee & $\begin{array}{l}\text { Age assigned by relative } \\
\text { stratigraphic position }\end{array}$ \\
\hline 07DL049 & 69.18763 & 148.56273 & early Turonian & Seabee & $\begin{array}{l}\text { Age assigned by relative } \\
\text { stratigraphic position }\end{array}$ \\
\hline 07DL050 & 69.18771 & 148.56052 & early Turonian & Seabee & $\begin{array}{l}\text { Age assigned by relative } \\
\text { stratigraphic position }\end{array}$ \\
\hline 07DL051 & 69.1865 & 148.55815 & early Turonian ${ }^{2}$ & Seabee & $\begin{array}{l}\text { Sample collected at this } \\
\text { station }\end{array}$ \\
\hline 07DL052 & 69.18613 & 148.55637 & Turonian & Seabee & $\begin{array}{l}\text { Age assigned by relative } \\
\text { stratigraphic position }\end{array}$ \\
\hline 07DL053 & 69.18578 & 148.55354 & Turonian & Seabee & $\begin{array}{l}\text { Age assigned by relative } \\
\text { stratigraphic position }\end{array}$ \\
\hline 07DL054 & 69.18509 & 148.55215 & $\begin{array}{l}\text { Late Albian to early } \\
\text { Turonian }{ }^{3} \text {; middle } \\
\text { Albian to early } \\
\text { Santonian'; Santonian } \\
\text { to Campanian } \\
\text { Santonian }\end{array}$ & $\begin{array}{l}\text { Seabee to } 66 \mathrm{~m} \text {; } \\
\text { Canning above } 66 \\
\text { m }\end{array}$ & $\begin{array}{l}0-66 \mathrm{~m} \text { in measured section } \\
07 \mathrm{DL} 054 \text { is considered } \\
\text { Turonian; above } 66 \mathrm{~m} \text { is } \\
\text { considered Santonian }\end{array}$ \\
\hline 07DL055 & 69.18333 & 148.54654 & $\begin{array}{l}\text { Middle Santonian to } \\
\text { early Campanian }\end{array}$ & Canning & $\begin{array}{l}\text { Age assigned by relative } \\
\text { stratigraphic position }\end{array}$ \\
\hline 07DL056 & 69.18271 & 148.54785 & $\begin{array}{l}\text { Middle Santonian to } \\
\text { early Campanian }\end{array}$ & Canning & $\begin{array}{l}\text { Sample collected at this } \\
\text { station }\end{array}$ \\
\hline 07DL057 & 69.18198 & 148.54623 & Campanian ${ }^{6,7}$ & Canning & $\begin{array}{l}\text { Age assigned by relative } \\
\text { stratigraphic position }\end{array}$ \\
\hline 07DL058 & 69.18057 & 148.54991 & Campanian,7 & Canning & $\begin{array}{l}\text { Age assigned by relative } \\
\text { stratigraphic position }\end{array}$ \\
\hline 07DL059 & 69.18 & 148.54715 & Campanian $^{6,7}$ & Canning & $\begin{array}{l}\text { Age assigned by relative } \\
\text { stratigraphic position }\end{array}$ \\
\hline 07DL060 & 69.17956 & 148.54491 & $\begin{array}{l}\text { Middle to late } \\
\text { Campaniann }\end{array}$ & Canning & $\begin{array}{l}\text { Age assigned by relative } \\
\text { stratigraphic position }\end{array}$ \\
\hline 07DL061 & 69.17878 & 148.5463 & Late Campanian ${ }^{7}$ & Canning & $\begin{array}{l}\text { Sample collected at this } \\
\text { station }\end{array}$ \\
\hline 07DL062 & 69.17801 & 148.54317 & Late Campanian ${ }^{7}$ & Canning & $\begin{array}{l}\text { Age assigned by relative } \\
\text { stratigraphic position }\end{array}$ \\
\hline 07DL063 & 69.17477 & 148.53581 & Late Campanian ${ }^{7}$ & $\begin{array}{l}\text { Canning or } \\
\text { Schrader Bluff }\end{array}$ & $\begin{array}{l}\text { Age assigned by relative } \\
\text { stratigraphic position }\end{array}$ \\
\hline 07DL064 & 69.17152 & 148.54272 & $\begin{array}{l}\text { Late Campanian"; } \\
\text { Campanian }^{8}\end{array}$ & Schrader Bluff & $\begin{array}{l}\text { Age assigned by relative } \\
\text { stratigraphic position }\end{array}$ \\
\hline 01DL021 & 69.162467 & 148.52 & $\begin{array}{l}\text { Late Campanian"; } \\
\text { Campanian }^{8}\end{array}$ & Schrader Bluff & $\begin{array}{l}\text { Probably late Campanian. Age } \\
\text { assigned by relative } \\
\text { stratigraphic position }\end{array}$ \\
\hline 01DL022 & 69.15538 & 148.49132 & Campanian $^{8}$ & Schrader Bluff & $\begin{array}{l}\text { Sample collected at this } \\
\text { station }\end{array}$ \\
\hline
\end{tabular}

\footnotetext{
${ }^{1}$ Turonian-Coniacian paly (Mull, unpublished data)

${ }^{2}$ Age based on Mytiloides labiatus (Mull, unpublished data).

${ }^{3}$ Composite palynologic sample between 45-58 m in measured section 07DL054 (Zippi report for DGGS, August 29, 2004).

${ }^{4}$ Palynologic sample at $84 \mathrm{~m}$ in measured section 07DL054 (Zippi report for DGGS, August 29, 2004).

${ }^{5}$ Composite palynologic sample between 85-91 m in measured section 07DL054 (Micropaleo Consultants, Inc., report for DGGS, January 2003).

${ }^{6}$ Age based on Sphenoceramus patootensis collected near station 056 (Mull, unpublished data).

${ }^{7}$ Palynologic sample between 6-10 m in measured section 07DL061 (Zippi report for DGGS, August 29, 2004).

${ }^{8}$ Campanian megafossils at station 01DL022 (Mull, unpublished data).
} 


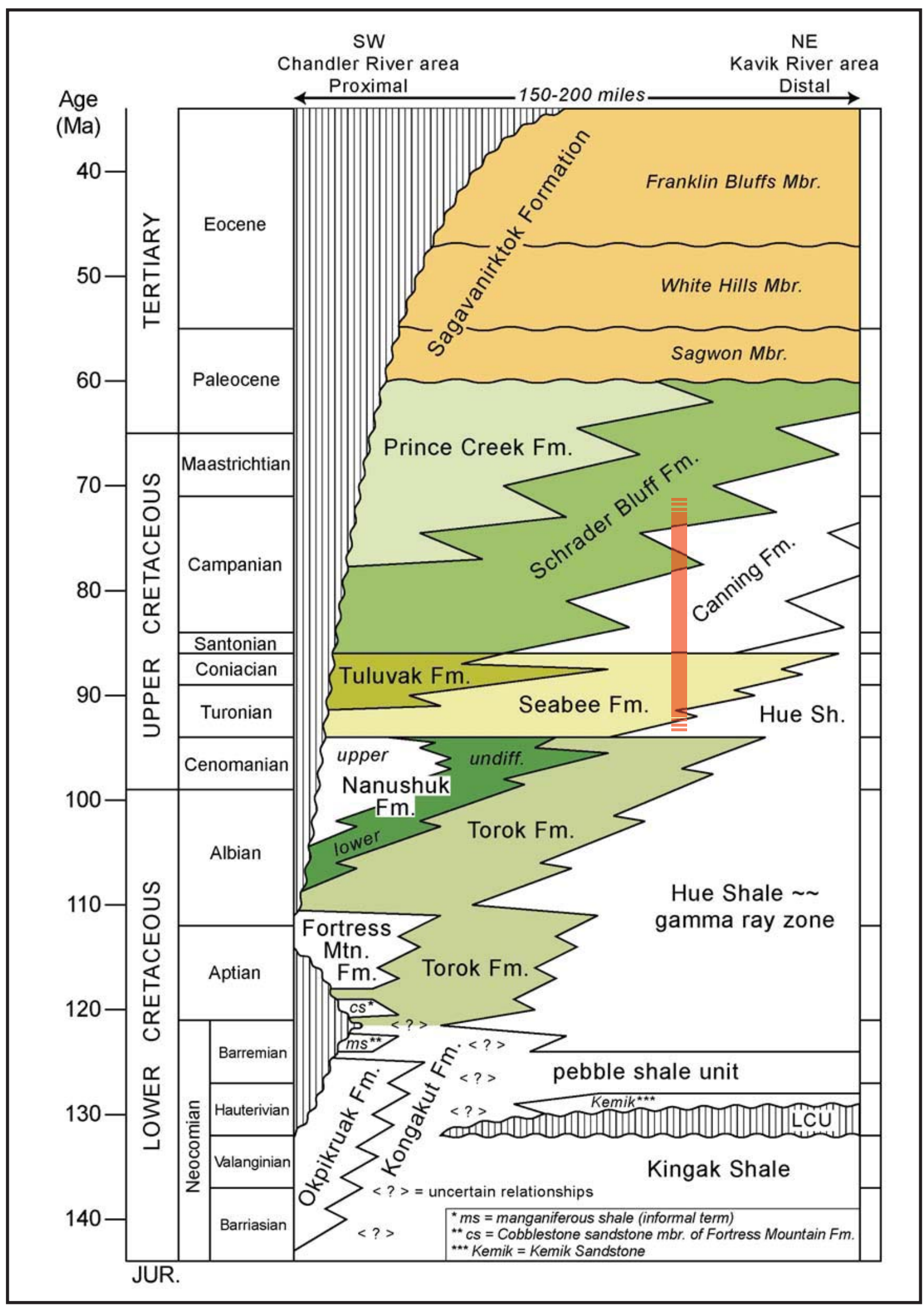

Mull and others (2003)

Figure 3. Generalized stratigraphic column showing Beaufortian and Brookian sequences in the central North Slope. The vertical red bar shows the approximate stratigraphic range of the succession addressed in this report. 
exposure. The top of the measured section shown in figure 5 corresponds to the north limb of this structure. An additional 50 to $100 \mathrm{~m}$ of interbedded sandstone and mudstone are poorly exposed immediately south of the fold (station 046).

The ages of these rocks are constrained by microfossil and macrofossil samples (Mull, unpublished data). Palynomorphs from this location suggest a Turonian to Coniacian age. The early Turonian bivalve Mytiloides labiatus is present up-section toward the southeast, in sandstones at station 051 (fig. 2). These data suggest the rocks at station 045 are lower Turonian.

Sandstones are well indurated to friable, light gray to buff weathering, medium gray on fresh surfaces, and very fine to fine grained. Some indurated beds are cemented with calcite and cut by calcite-filled veins (fig. 6a). Bed thicknesses range from a few centimeters to nearly one meter and contacts are typically planar and parallel. Sandstone is present as single beds up to $20 \mathrm{~cm}$ thick bounded by mudstone; amalgamated beds (sand-on-sand contacts) up to $60 \mathrm{~cm}$ thick form bedsets up to $2 \mathrm{~m}$ thick (fig. 6b). Discontinuous mudstones a few centimeters thick are present in some bedsets, demonstrating incomplete amalgamation locally. Fresh sandstone surfaces in the upper half of the exposure have a strong hydrocarbon odor.

Sedimentary structures are difficult to see throughout most of the exposure and most beds appear internally massive. Mudstone rip-up clast impressions (fig. 6c) and sole markings, including linear groove and load-enhanced flute casts, are present on the bases of some sandstone beds. Normal size grading is present in a few beds in the lower $14 \mathrm{~m}$ of the succession and some beds throughout the exposure include plane-parallel lamination and equivocal examples of small-scale trough cross-bedding and ripple bedforms. The distribution of these structures suggests Bouma $\mathrm{Ta}, \mathrm{Tb}$, and Tbc beds. Scour surfaces within sandstone bedsets are common and locally overlain by scattered sideritized(?) mudstone clasts, marking amalgamation surfaces. Trace fossils have not been recognized (II1; ichnofabric index of Droser and Bottjer, 1986). Mudstones are poorly exposed and their sedimentary structures are not visible.

\section{INTERPRETATION}

Bouma Ta, Tb, and Tbc beds and associated sole markings suggest deposition from turbidity currents (facies $\mathrm{D}$ or E of Mutti and Ricci Lucchi, 1978; Weimer and Slatt, 2007). Massive beds represent either lags from energetic flows that transported finer material to more distal settings (favored interpretation; Pickering and others, 1986; Mutti and Normark, 1987) or rapid deposition from flows carrying a limited range of grain sizes. Mudstone rip-up clast impressions and flute and groove casts are all consistent with deposition from turbulent flows.

Publicly available subsurface data suggest deposition basinward (east and north) of the terminal Nanushuk shelf edge (Molenaar and others, 1986; Houseknecht and Schenk, 2001; 2004). Parallel and laterally continuous seismic reflections characterize probable Turonian strata, suggesting deposition in a basin floor setting (Decker, oral commun.). We tentatively suggest the succession represents two overlapping sandstone lobes separated by $4.5 \mathrm{~m}$ of mudstone. The two sandstone packages could represent shingled lobe deposits, with the younger lobe offset laterally (compensation bedding).

Available biostratigraphic data suggest correlation with the Seabee Formation west of the Trans-Alaska pipeline corridor.

\section{Station 07DL046 \\ DESCRIPTION}

Station 046 is located on the north side of the synform noted at station 045 (figs. 2 and 4). Approximately 50 to $100 \mathrm{~m}$ of interbedded sandstone and mudstone are poorly exposed at this station. The distribution of rubblecrop and sandstone slabs in float suggest bedding dips toward the south-southeast, comparable to bedding on the north limb of the synform. Stratigraphic up is toward the north.

Sandstones are well indurated, light buff weathering and light gray on fresh surfaces, and very fine to fine grained. Light gray to gray translucent grains of chert and quartz are the dominant framework grains in hand sample, whereas black chert is a conspicuous but minor component. Bed geometry appears similar to sandstones at station 045. Mudstone rip-up clast impressions are common. Sandstones appear internally massive and mudstone is only visible as float in holes dug by animals.

\section{INTERPRETATION}

Interpretation of the depositional setting is not possible given the exposure quality. Available biostratigraphic data suggest correlation with the Seabee Formation west of the Trans-Alaska pipeline corridor. 


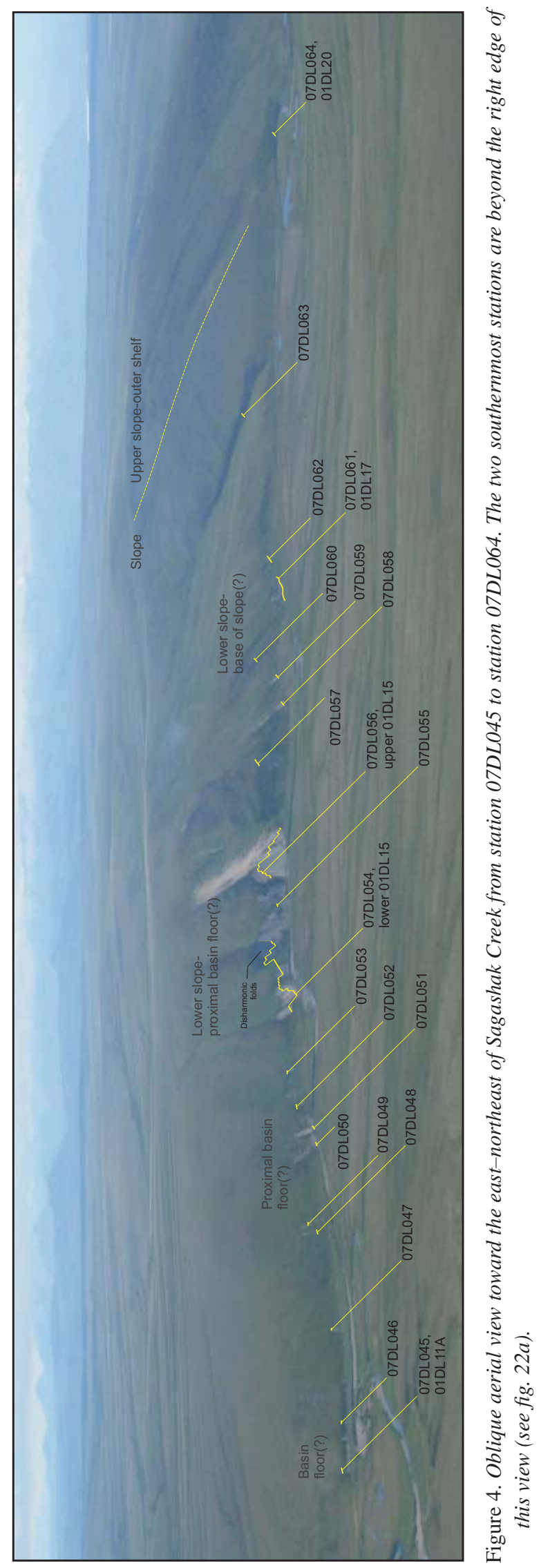




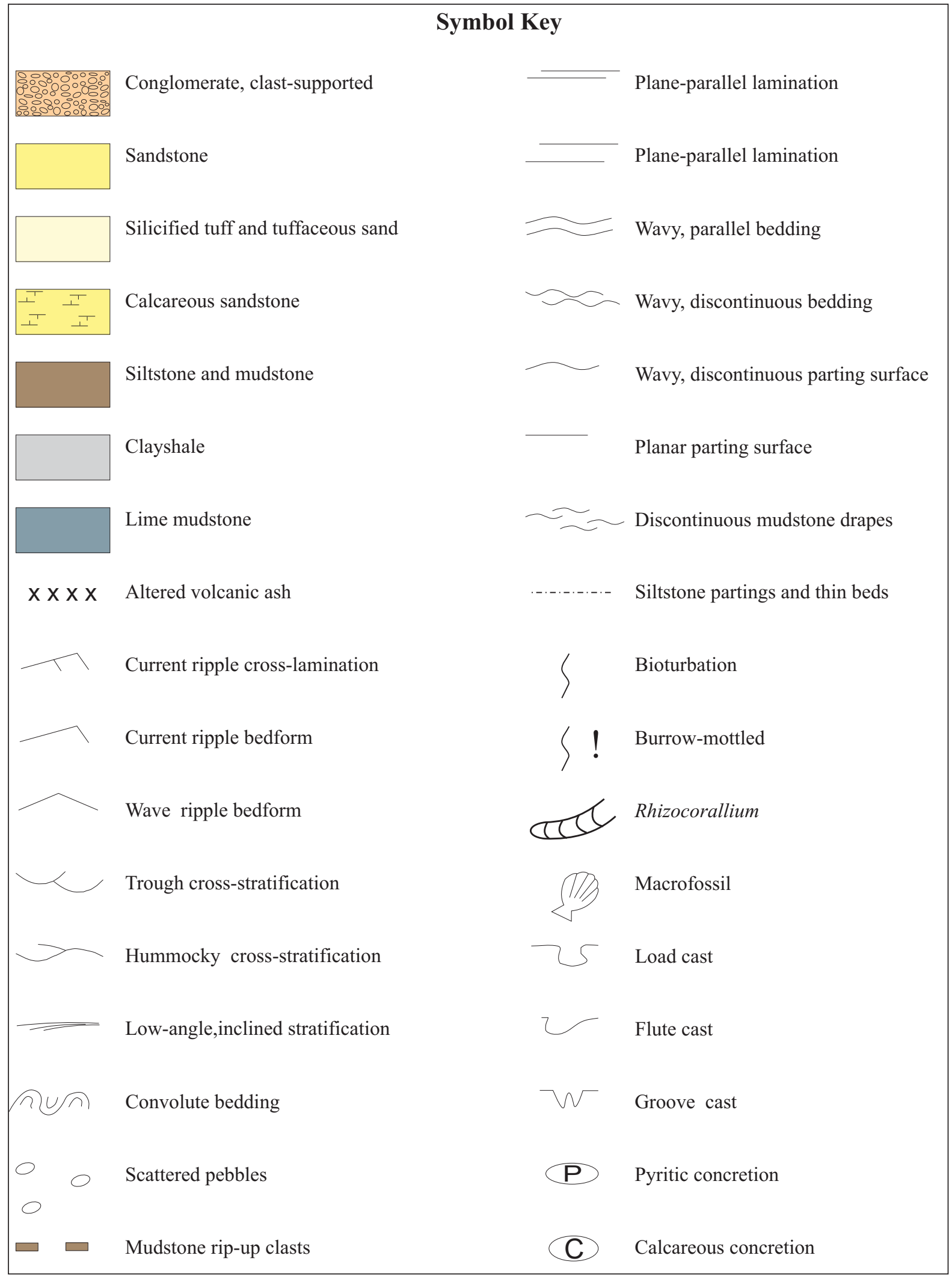

Figure 5. Measured stratigraphic section through Turonian turbidites and associated hemipelagic deposits of the distal Seabee Formation at station 07DL045. 
07DL045

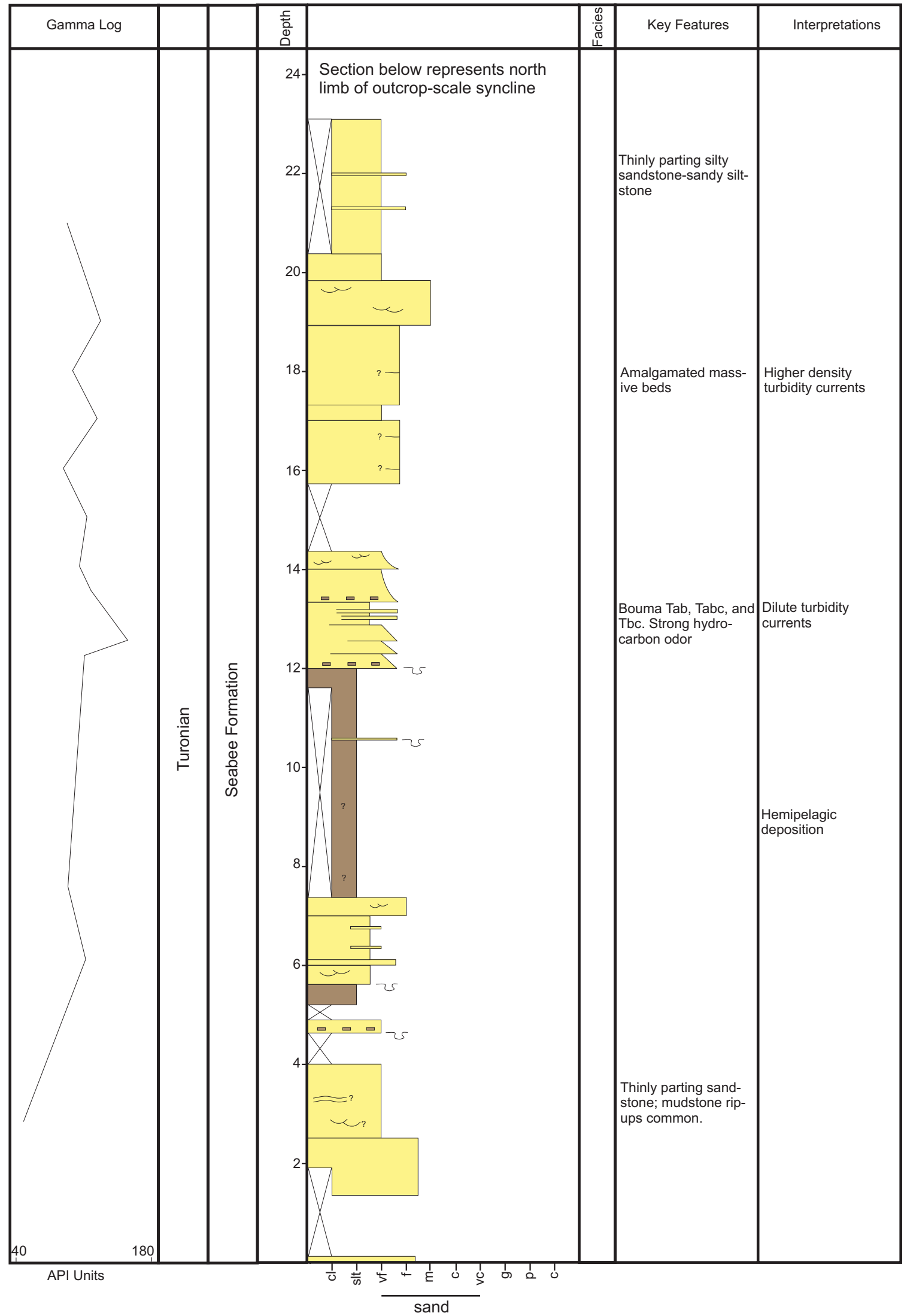

Figure 5. Measured stratigraphic section through Turonian turbidites and associated hemipelagic deposits of the distal Seabee Formation at station 07DL045. 


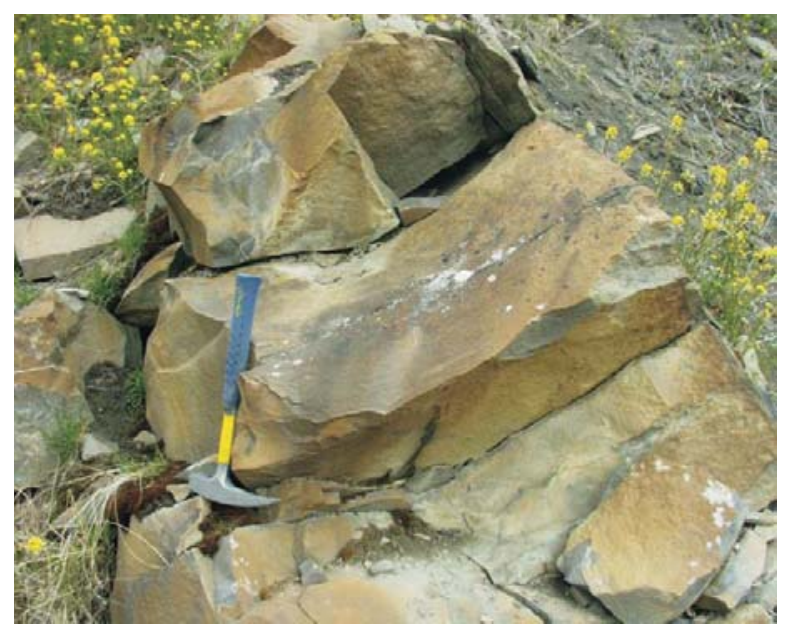

A.

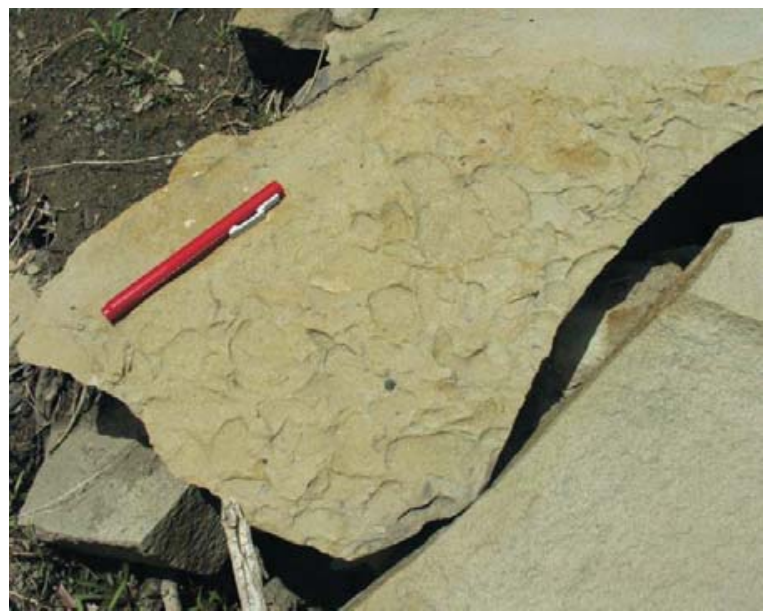

C.

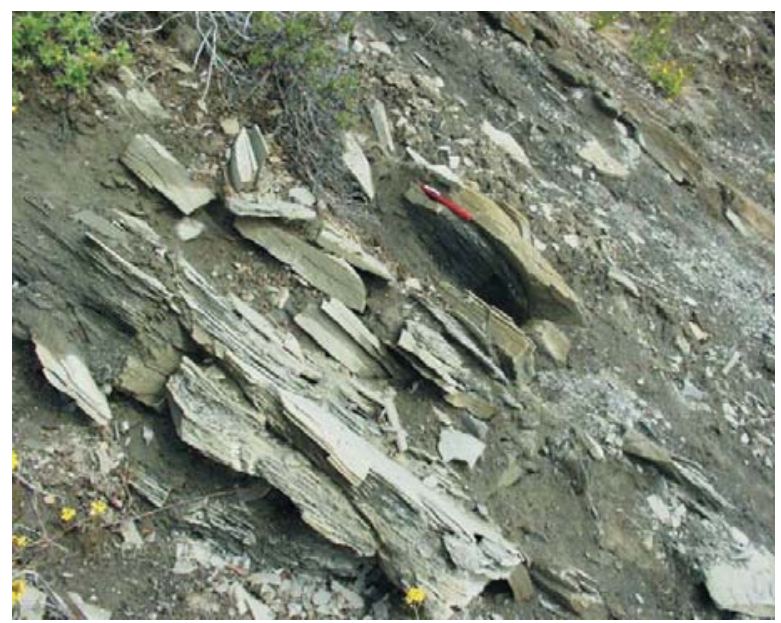

B.

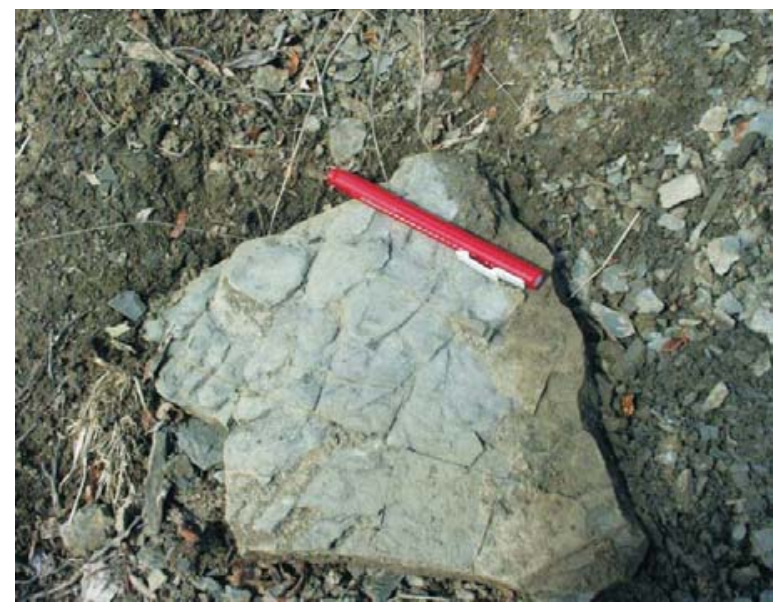

D.

Figure 6. Photographs of sedimentary features in the distal Seabee Formation at station 07DL045. (A) Calcite-cemented sandstone from 1.7-2.6 $\mathrm{m}$. Note the calcite-filled vein immediately to the right of the hammer handle. (B) Thinly parting sandstone in amalgamated beds between 16 and $18 \mathrm{~m}$. (C) Molds of mudstone rip-up clasts preserved on the underside of a sandstone bed at $12 \mathrm{~m}$. (D) Load-enhanced flute casts in float.

\section{Station 07DL047}

\section{DESCRIPTION}

Station 047 (figs. 2 and 4) consists of a coherent line of sandstone rubble that extends from river level up-slope 20 to $30 \mathrm{~m}$ toward the northeast. The station is not visible from the air as a rubble-covered ridgeline. Bedding appears to dip 40 degrees toward the northwest, but stratigraphic facing direction is unclear. The sandstone bed or bedset weathering out of the slope at this location is approximately $1.5 \mathrm{~m}$ thick, is brown weathering, light gray on fresh surfaces, and very fine to fine grained. The lower 1.0-1.3 $\mathrm{m}$ of the rubblecrop have a frost-shattered appearance and parting surfaces are wavy to irregular shaped. The uppermost $20-50 \mathrm{~cm}$ of the rubblecrop is characterized by thin flaggy parting, possibly reflecting thinner horizontal bedding. Load casts and equivocal current ripple bedforms are present in float.

\section{INTERPRETATION}

Features recognized at station 047 are similar to those described at station 045 and are similarly interpreted. The absence of a visible line of rubble from the air away from the river suggests a lenticular sand body geometry. Available biostratigraphic data suggest correlation with the Seabee Formation west of the Trans-Alaska pipeline corridor. 


\section{Stations 07DL048 and 07DL049 \\ DESCRIPTION}

Stations 048 and 049 are separated by 30 to $40 \mathrm{~m}$ of tundra cover (figs. 2 and 4). Both stations consist of rubblecrop 2-3 m thick. Bedding at both stations is estimated to dip 70 degrees toward the southeast. Stratigraphic facing direction is inferred to be south, but is questionable. Sandstone at station 048 is well indurated, light gray to orange-brown weathering, light to medium gray on fresh surfaces, and very fine to fine grained. Some rocks appear green-gray on fresh surfaces. Parting character suggests wavy continuous beds; bed thickness is unknown. Scattered mudstone rip-up clasts up to a few millimeters long are present in the sandstones. Load-enhanced flute casts are present on sandstone slabs in float, indicating the presence of shaly interbeds (fig. 6d).

Sandstone at station 049 is well indurated, buff to brown weathering, light gray on fresh surfaces, and fine grained. Parting character is irregular and sandstone breaks easily in small chips and irregular pieces. Mudstone rip-up impressions up to a few centimeters long are common in sandstone float.

\section{INTERPRETATION}

Features similar to those described at station 045 suggest similar depositional processes. Available biostratigraphic data suggest correlation with the Seabee Formation west of the Trans-Alaska pipeline corridor.

\section{Station 07DL050 \\ DESCRIPTION}

Station 050 is the next rubblecrop southeast of station 049 (figs. 2 and 4). Approximately 2-4 m of well indurated, rusty red-brown weathering sandstone is exposed. Bedding dips 34 degrees toward the northwest, but definitive way-up indicators have not been found in place. On fresh surfaces sandstones are medium to dark gray, very fine grained, and locally have a sulfurous odor. Bedding character is difficult to assess; some slabs in rubble are bounded by gently curving, irregular fracture surfaces, and other parts of the exposure appear more or less in place and display a thin, wavy parting character. No size grading or sedimentary structures have been recognized. Fracture and parting character suggest the presence of internally massive medium-bedded and thin, wavy-bedded sandstones. Chippy siltstone and lower very-fine-grained sandstone are present as float in recessive-weathering intervals within the rubblecrop. Similar chippy siltstone and small pieces of very-fine-grained sandstone are present as float approximately 15-20 m southeast of the exposure.

\section{INTERPRETATION}

Deposition in a deep-water setting is inferred based on regional context (Molenaar and others, 1986; Houseknecht and Schenk, 2004). More detailed interpretation is not possible given the exposure quality. Available biostratigraphic data suggest correlation with the Seabee Formation west of the Trans-Alaska pipeline corridor.

\section{Station 07DL051 \\ DESCRIPTION}

Station 051 is the first significant intact outcrop southeast of stations 045 and 046, and consists of $18 \mathrm{~m}$ of relatively well-exposed shale, siltstone, and sandstone (figs. 2, 4, and 7). Rubble of red-orange weathering veryfine- to fine-grained sandstone extends approximately $12 \mathrm{~m}$ below the base of the exposure toward the northwest, and shale and very-fine- to fine-grained sandstone are poorly exposed immediately south of the exposure. Beds dip 60 degrees toward the south and sole markings indicate the section is not overturned. In contrast, sole markings on sandstones thought to be in place immediately southeast of the exposure suggest bedding is overturned and that the southeast end of the exposure at station 051 represents the upright limb of a syncline.

The age of this succession is constrained by well-preserved impressions of the early Turonian bivalve Mytiloides labiatus (fig. 8a).

The lower $9 \mathrm{~m}$ at station 051 consists of discontinuously exposed light green-gray weathering fissile clay shale and olive-gray weathering chippy siltstone with minor interbedded rusty red-brown and yellow weathering, very-fine- to fine-grained sandstone (fig. 8b). Siltstone is locally red-brown stained with millimeter-scale laminae visible on fresh surfaces. Sandstone beds range from a few centimeters to decimeters thick. Sedimentary structures include small bulbous load casts (fig. 8c) and current ripple cross-lamination suggestive of Bouma Tc beds. Some beds are plane-parallel laminated (Bouma $\mathrm{Tb}$ ). At least one 1-m-thick bedset of very-fine-grained sandstone with irregular parting surfaces suggestive of small-scale trough cross-bedding is present. Many beds have a bioturbated appearance (fig. 8d). 
07DL051

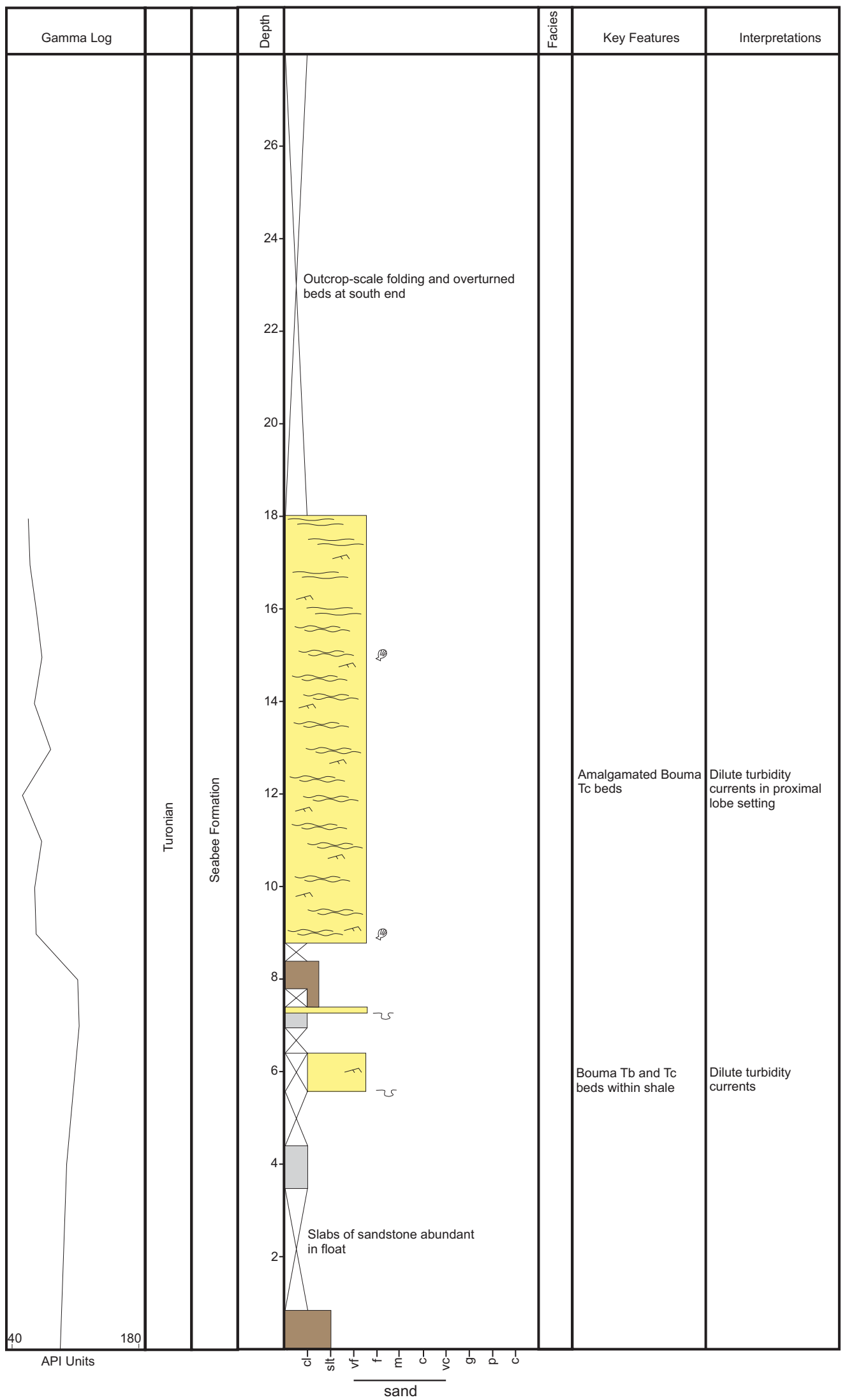

Figure 7. Measured stratigraphic section through Turonian turbidites of the distal Seabee Formation at station 07DL051. See figure 5 (p. 92) for symbol key. 

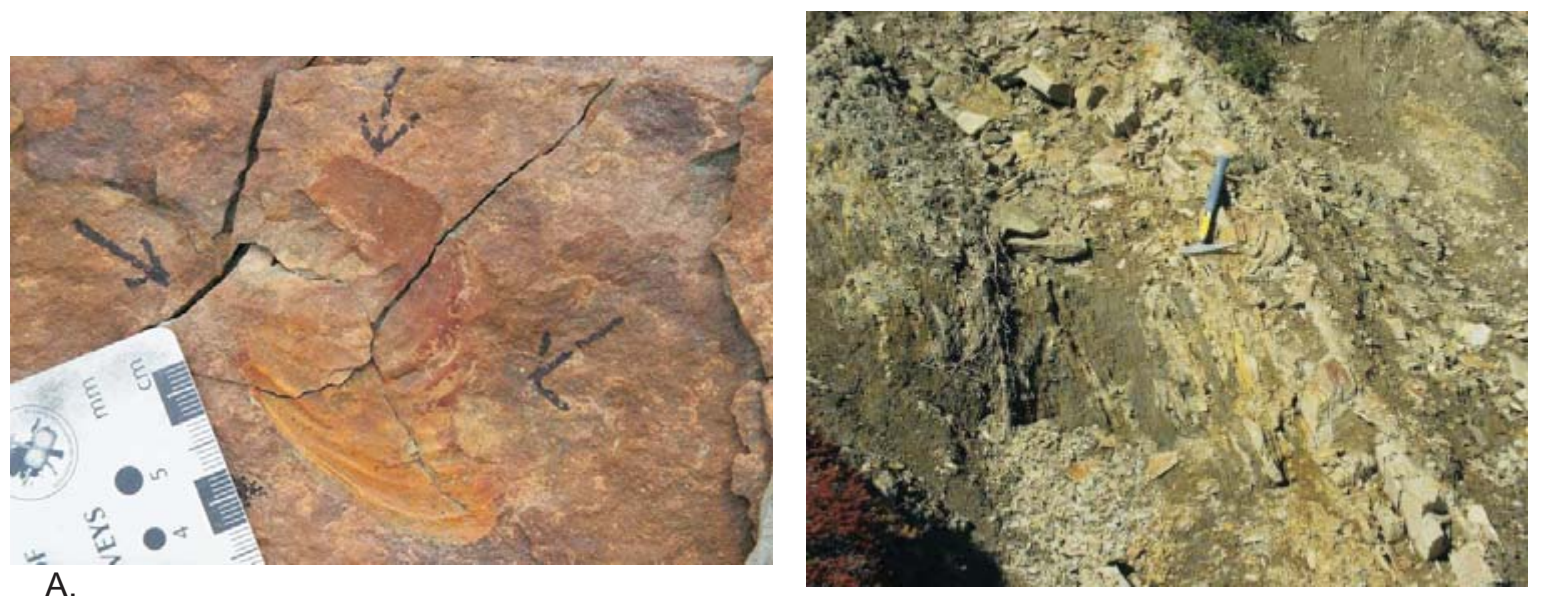

B.

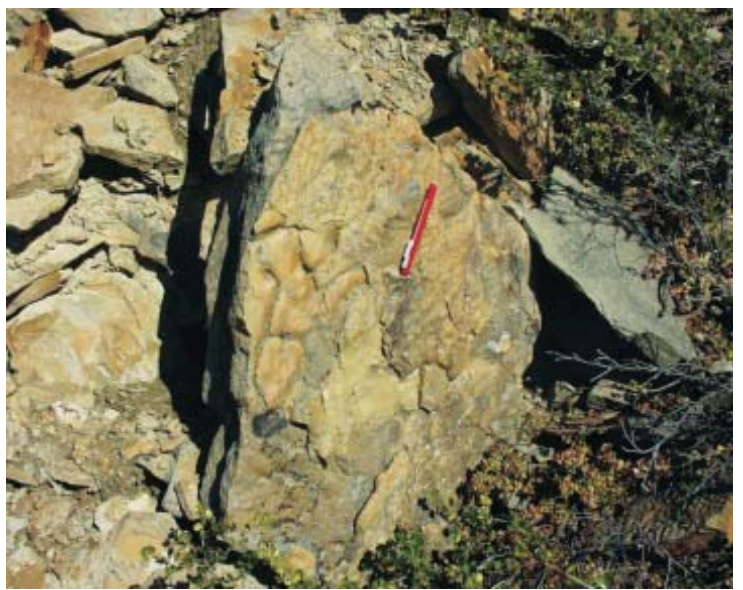

C.

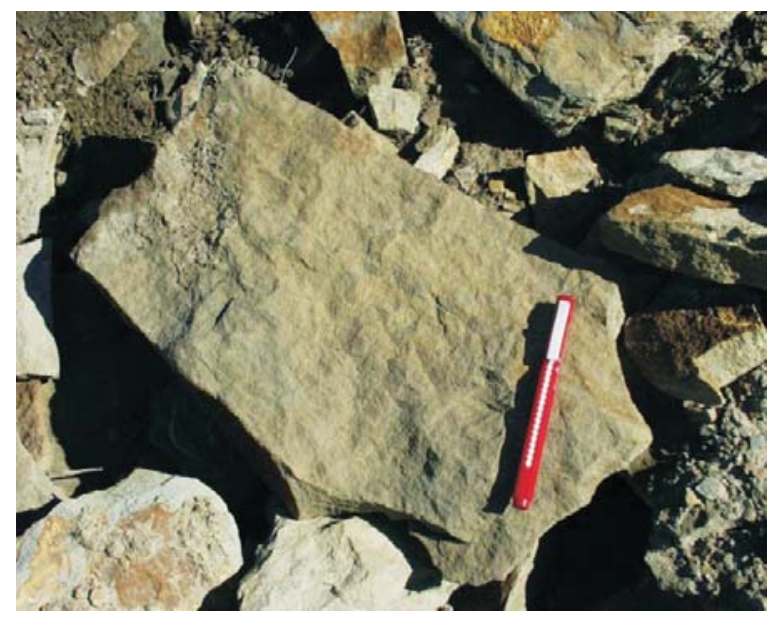

D.
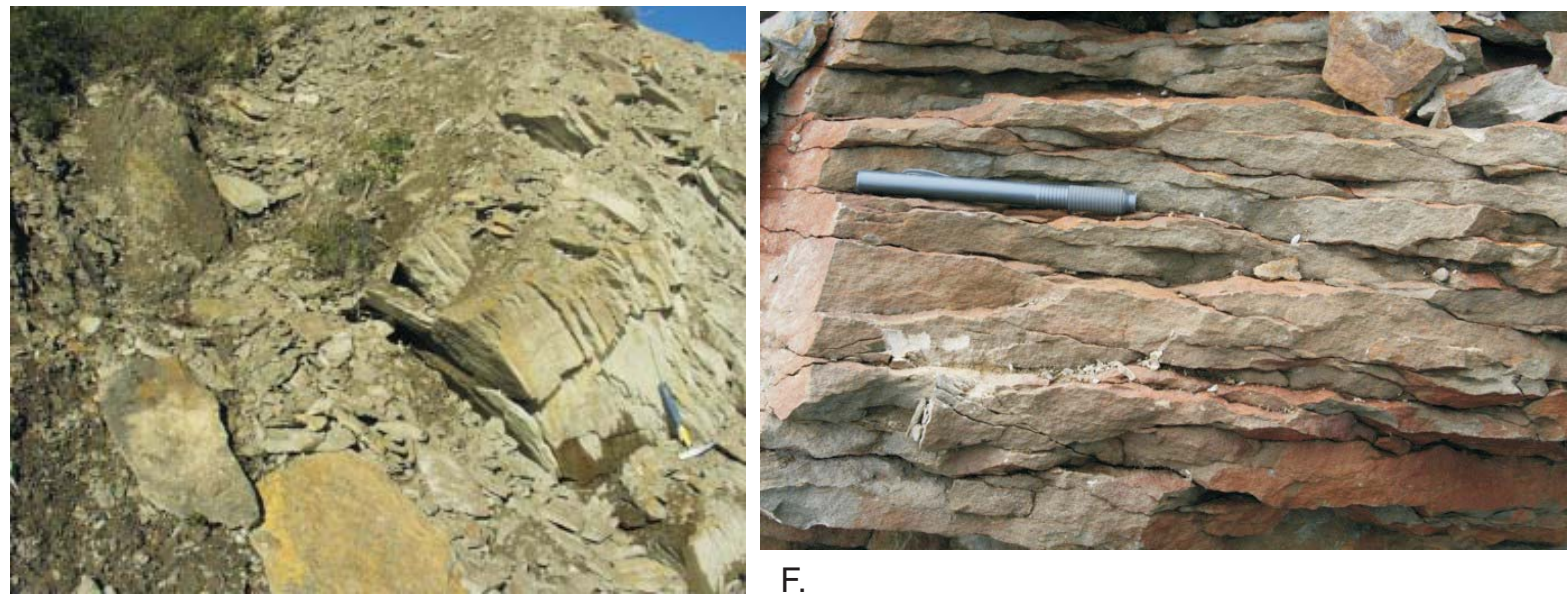

$\mathrm{F}$.

E.

Figure 8 (A-F). Photographs of sedimentary features through Turonian turbidites and associated hemipelagic deposits of the distal Seabee Formation at station 07DL051. (A) Impression of early Turonian clam Mytiloides labiatus in iron-stained sandstone at $9 \mathrm{~m}$. (B) Thinly interbedded very-fine-grained sandstone and silty claystone at $6 \mathrm{~m}$. (C) Load casts on the underside of a sandstone bed above $18 \mathrm{~m}$. The orientation of this bed suggests the presence of an outcrop-scale fold and vertical to overturned beds on the southeast limb. Measured section 07DL051 was measured on the northwest limb. (D) Bioturbated appearance of sandstone on an irregular parting surface. (E) Contact between amalgamated sandstone beds and siltstone at $8.7 \mathrm{~m}$. (F) Thin, discontinuous sandstone beds at $10 \mathrm{~m}$. 


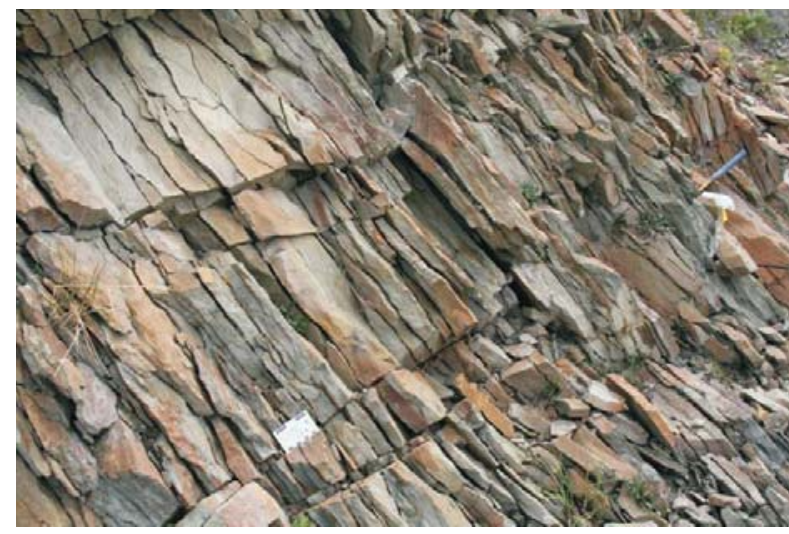

G.

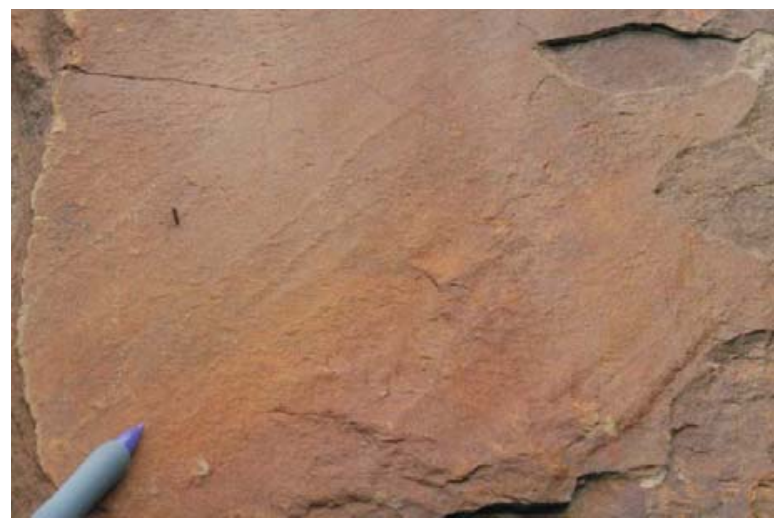

I.

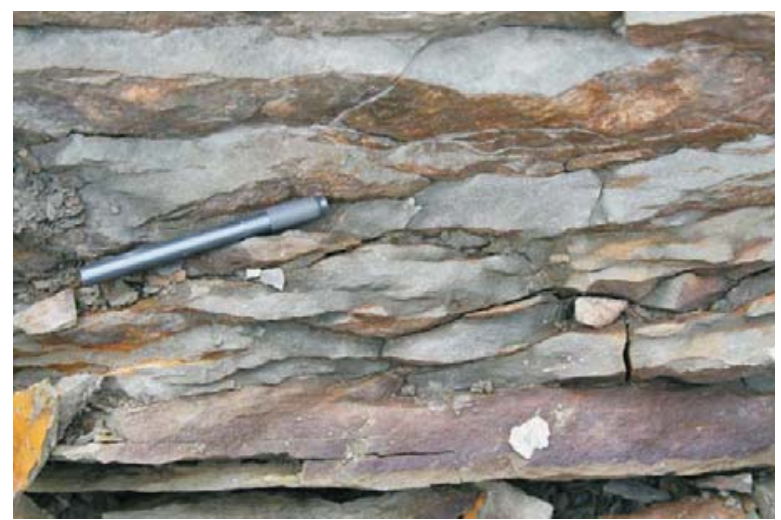

H.

Figure 8 (G-I). Photographs of sedimentary features through Turonian turbidites and associated hemipelagic deposits of the distal Seabee Formation at station 07DL051. (G) Slightly thicker, discontinuous sandstone beds near $16 \mathrm{~m}$. The lower edge of the white scale is graduated in centimeters and the top edge in inches. (H) Concave-up surfaces overlain by concave-up gently dipping foreset laminae of small-scale trough cross beds near 16 m. (I) Parting lineation visible on sandstone parting surface in float.

The upper $9 \mathrm{~m}$ consists entirely of an amalgamated succession of red-brown weathering very-fine- to finegrained sandstone. The contact with underlying shale is sharp (fig. 8e) and linear groove and prod marks are visible on the underside of the basal sand bed. Sandstone is light to medium gray on fresh surfaces, which give off faint hydrocarbon and sulfur odors. Parting surfaces typically have a burrow-churned, disrupted appearance (fig. 8a). Bedding is discontinuous and ranges from 0.5 to $5 \mathrm{~cm}$ near the base (fig. 8f) and gradually thickens upward to 5 to $7 \mathrm{~cm}$ near the top (fig. 8g). Faint, gently-dipping to concave-up laminae are visible locally and concave-up parting surfaces are common, both of which suggest small-scale trough cross-bedding in sets up to $10 \mathrm{~cm}$ thick (fig. 8h). Parting planes throughout the amalgamated succession are coated with a red-brown sub-millimeter-thick film. The film is either an exceedingly thin clay drape or, more likely, an oxide coating of some sort. Lineations (fig. 8i) and minor sideritized(?) mudstone rip-up clasts are present on parting surfaces throughout the sand body; rip-up clast impressions up to $5 \mathrm{~cm}$ across are abundant throughout the upper few meters of the sand body. Well-preserved unbroken bivalve impressions of Mytiloides labiatus are present on scattered parting surfaces as concave-upward depressions (fig. 8a). If these occurrences represent impressions of disarticulated valves, the valves were deposited in the hydrodynamically-unstable concave-side-up position. Casts of the complete clam (both valves articulated as in life) have not been found. Freshly broken pieces of sandstone have faint hydrocarbon and sulfur odors.

\section{INTERPRETATION}

The lower $9 \mathrm{~m}$ records deposition in a low-energy setting that was interrupted intermittently by dilute turbidity currents depositing Bouma Tb and Tc beds on the distal fringe of a sandstone lobe (lobe fringe in the sense of Mutti and Normark, 1987). Rip-up clasts and small-scale trough cross-bedding suggest that sandstone in the upper $9 \mathrm{~m}$ was deposited from turbulent flows involving traction transport of very-fine- to fine-grained sandy bedload and development of small-scale three-dimensional bedforms. The apparent absence of laterally continuous beds makes recognition of individual turbidite event beds difficult, and highlights the presence of intersecting scour features throughout the sand body. This part of the succession is tentatively interpreted as the depositional products of a series of dilute turbidity currents that deposited a series of Bouma Tc beds. Each event involved enough turbulent 
scour in the head of the flow to remove finer-grained deposits, resulting in amalgamated Tc beds. The churned, disrupted appearance of most parting surfaces suggests the presence of a burrowing fauna. However, common undisturbed (or minimally disturbed) lamination indicates not all beds were subjected to the disrupting activities of burrowing organisms.

Characteristics described above for the upper 9-m-thick sandstone body are consistent with deposition as channel-lobe transition or proximal lobe deposits (Mutti and Normark, 1987), possibly in a channelized setting. Subsurface control (Decker, written commun.; Molenaar and others, 1986) suggests deposition in a basin floor position, which is consistent with sandstone lobe deposition.

The presence of well-preserved disarticulated clam shells in the hydrodynamically-unstable concave-up position in a deep-water succession seems problematic. Although M. labiatus shells can be thick-walled and robust (Will Elder, written commun.), significant transport as bedload should have resulted in significant abrasion and some breakage, yet the valve impressions in these rocks do not clearly show these signs. It is possible that disarticulated shells were rafted to the depositional site on the underside of seasonal ice flows that formed in nearshore locations where the shells were incorporated in the base of ice. Subsequent seasonal warming allowed ice flows to break up and carry their entrained load, including the occasional clam shell, seaward to deeper water. A concave-up resting position might be expected for valves that settled through a low-energy water column. The presence of seasonal ice is reasonable given the 75 to 85 degrees north latitude of northern Alaska during the Late Cretaceous (Spicer and others, 1992).

Available biostratigraphic data suggest correlation with the Seabee Formation west of the Trans-Alaska pipeline corridor.

\section{Station 07DL052 \\ DESCRIPTION}

Station 052 is an inconspicuous rubbly exposure east-southeast of station 051 (figs. 2 and 4). Rubblecrop on the west side of the location includes approximately $10 \mathrm{~m}$ of light gray to light brown weathering very-fine- to fine-grained sandstone. Rusty red-brown weathering sandstone is present locally. Load casts are common. Wavy discontinuous internal surfaces visible on some pieces of float are suggestive of current ripple cross-lamination or small-scale trough cross-bedding. Silty claystone is present as float 25 to $30 \mathrm{~m}$ east-southeast of the sandstone rubble, where tundra vegetation is absent. A possible ash consisting of yellow weathering clayey material is intermixed with the silty claystone float.

\section{INTERPRETATION}

The presence of load casts and possible current ripple cross-lamination are consistent with deposition as Bouma Tc beds from dilute turbidity currents. The silty claystone in float 25 to $30 \mathrm{~m}$ above the sandy rubblecrop records background hemipelagic sedimentation. More detailed interpretation is not possible given the limited exposure. Regional constraints suggest deposition in a deep-water setting (Molenaar and others, 1986; Houseknecht and Schenk, 2004).

Available biostratigraphic data suggest correlation with the Seabee Formation west of the Trans-Alaska pipeline corridor.

\section{Station 07DL053 \\ DESCRIPTION}

Station 053 consists of approximately $3 \mathrm{~m}$ of rusty brown weathering very-fine-grained sandstone or coarse siltstone (figs. 2 and 4). Bedding is thin, wavy, and discontinuous.

\section{INTERPRETATION}

Such limited exposure precludes environmental interpretation. Nearby seismic data suggest deposition in a deep-water setting (Molenaar and others, 1986). Available biostratigraphic data suggest correlation with the Seabee Formation west of the Trans-Alaska pipeline corridor.

\section{Station 07DL054 \\ Description}

Station 054 spans two prominent east-west-trending ridges (figs. 2, 4, and 9). Complex disharmonic folds in a succession of thinly interbedded shale, sandstone, and silicified tuff are exposed on the north-facing slope of the southern ridge. Bedding on the north side of the exposure dips 48 degrees toward the south. 
The age of the succession is bracketed by an early Turonian bivalve Mytiloides labiatus at station 051 and a Santonian bivalve Sphenoceramus near station 056 (Mull, unpublished data). A palynologic sample collected near $28 \mathrm{~m}$ yielded an early Turonian? age, and a composite palynologic sample collected between 84 and $90 \mathrm{~m}$ yielded an early Santonian age (fig. 9; LePain, unpublished data). The age of the succession most likely ranges from late Turonian to Santonian.

The lower two-thirds of the exposure consists of thinly interbedded silty shale, siltstone, and sandstone $66 \mathrm{~m}$ thick (fig. 10a). Sandstone is buff to light gray weathering, medium gray on fresh surfaces, and very fine to fine grained. Bedding in sandstone ranges from less than $1 \mathrm{~cm}$ to $80 \mathrm{~cm}$, but thickness is commonly $2-20 \mathrm{~cm}$. Most sandstone beds are present as single event beds; amalgamated beds are present, but not abundant. Detrital white mica is a minor $(>1 \%)$, but distinctive component in sandstone. Interbedded silty shale and siltstone ranges from a few centimeters to $8 \mathrm{~m}$ thick, is dark to medium gray weathering, and displays a characteristic chippy parting. Sandstones near the top of the lower two-thirds of the exposure, on the north side of the gully below the disharmonic folds (fig. 10b), are visibly hydrocarbon stained and have a strong hydrocarbon odor.

A limited variety of sedimentary structures have been recognized in this part of the succession and, most commonly, sandstone beds appear internally massive. Normal size grading has only been recognized in the lower few meters of the succession, where it is associated with plane-parallel lamination and ripple cross-lamination and forms the base of Bouma Tabc and Tac beds. Elsewhere in the exposure, plane-parallel and ripple cross-lamination are associated with Bouma Tb, Tbc, and Tc beds. Sole markings, including load and groove casts (fig. 10c), are common throughout the succession. Flute casts are present but not common. Parting lineations are visible on many bed tops and some appear to be related to linear sole markings present on the underside of overlying sandstone beds in which scour during the formative event stripped away intervening mudstones and cut into the lower sand (fig. 10d). Discoid mudstone rip-up clasts (or empty molds of rip-up clasts) are common on parting surfaces (fig. 10e); rip-up clasts range from less than $1 \mathrm{~cm}$ to $15 \mathrm{~cm}$ (fig. 10f).

The upper third of the exposure, including the folded strata mentioned above, consists of approximately $31 \mathrm{~m}$ of slightly silty clay shale with thinly interbedded siltstone, sandstone, silicified tuff, and minor lime mudstone (fig. 9). The upper $18 \mathrm{~m}$ of this succession is complexly folded (fig. 10g); folding does not involve underlying or overlying strata. Shale weathers light to medium gray, is dark chocolate brown on fresh surfaces, appears organicrich (fig. 10h), and commonly displays a papery fissility. Siltstone is present as discrete interbeds $1-4 \mathrm{~cm}$ thick and accounts for the bulk of at least one coarsening-upward succession (74-76 m on fig. 9). Sandstone weathers brown to light gray, is lower very fine grained, in beds ranging from $>1 \mathrm{~cm}$ to $15 \mathrm{~cm}$, and is typically plane-parallel laminated (Bouma Tb beds). Tuff beds are medium gray to dark red-brown weathering, are dark gray to brown on fresh surfaces, typically plane-parallel laminated, in beds ranging from $>1 \mathrm{~cm}$ to $15 \mathrm{~cm}$ thick, and silicified (fig. 10i). The weathered surfaces of some tuff beds have a discontinuous coating of a yellow-white precipitate (gypsum?). All tuff beds have strong hydrocarbon odors. Altered volcanic ash (bentonite) layers up to $2 \mathrm{~cm}$ thick are common (fig. 10j).

\section{INTERPRETATION}

Thinly interbedded sandstone and siltstone in the lower two-thirds of the succession resemble facies D turbidites of Mutti and Ricci Lucchi (1978) and are interpreted as the products of dilute turbidity currents in a proximal(?) basin floor or lower slope setting. The thin-bedded nature of most sandstones and the minor presence of amalgamated sandstone beds is consistent with deposition as the distal part of a sandstone lobe (lobe fringe) or channel levee.

Finer-grained facies in the upper third of the succession are interpreted as a condensed section recording deposition in a sediment-starved setting, either in a lower slope or basinal position. The abrupt decrease in grain size above $66 \mathrm{~m}$ (fig. 9) suggests correlation with a prominent flooding surface on the shelf to the west that may correspond to the top of the Tuluvak Formation (fig. 3). Tuff beds originated from airfall ash that settled through the water column (submarine ashfall). We suggest the folded section above $84.8 \mathrm{~m}$ (fig. 9) corresponds, at least in part, to a maximum flooding zone, and that folding is the result of mass wasting of slope sediment (facies $\mathrm{F}$ of Mutti and Ricci Lucchi, 1978). We tentatively correlate the lower $66 \mathrm{~m}$ of strata at station 054 with the Turonian Seabee Formation west of the Trans-Alaska pipeline corridor. Beds above $66 \mathrm{~m}$ are considered part of the Canning Formation (for example, turbidite sandstone facies of Molenaar and others, 1987; 1986). 
07DL054

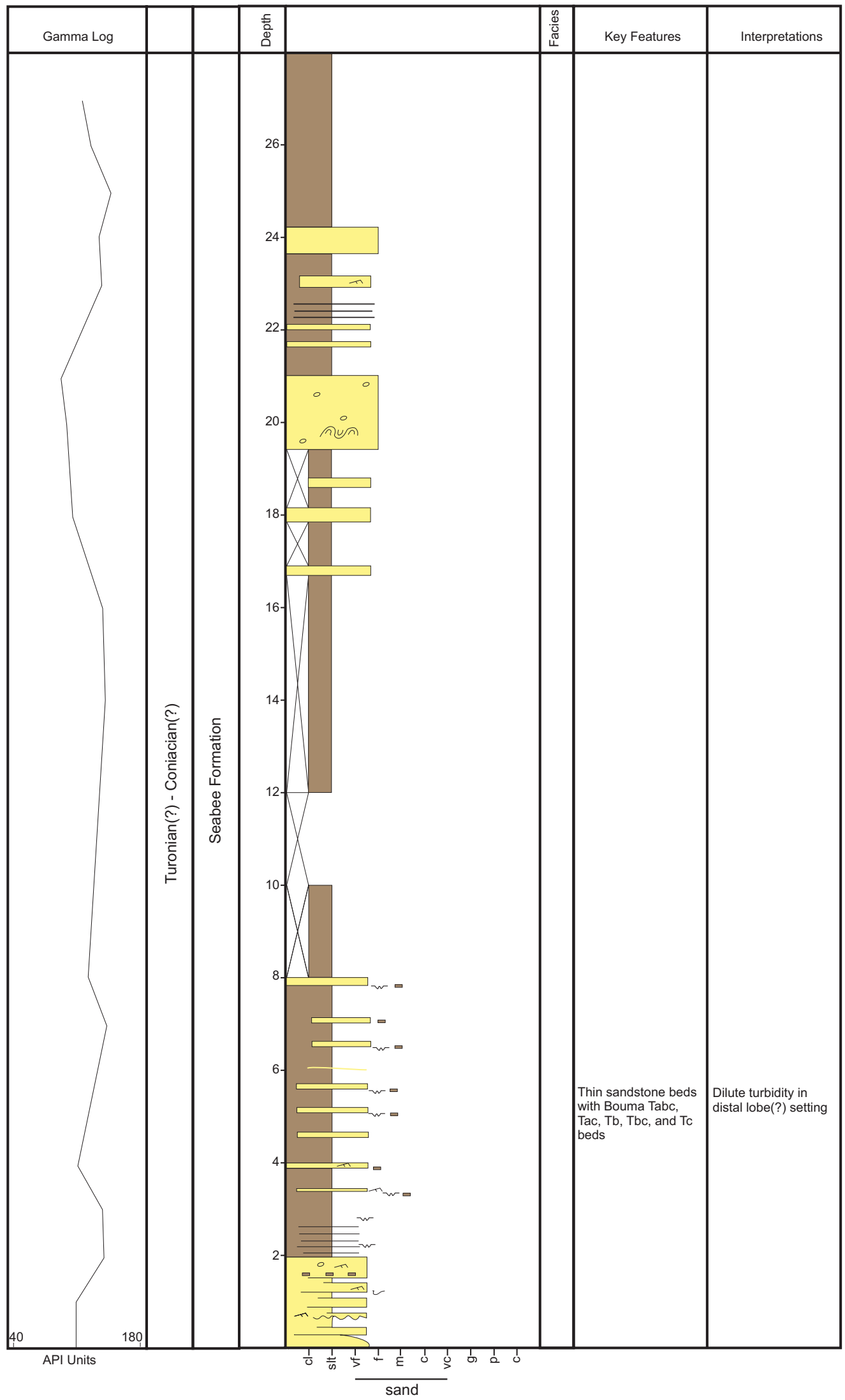

Figure 9. Measured stratigraphic section through turbidites and associated hemipelagic deposits of the distal Seabee and Canning Formations. Organic-rich clayshale and silicified tuffs above 50 m may represent a tongue of the Hue Shale. See figure 5 (p. 92) for symbol key. 


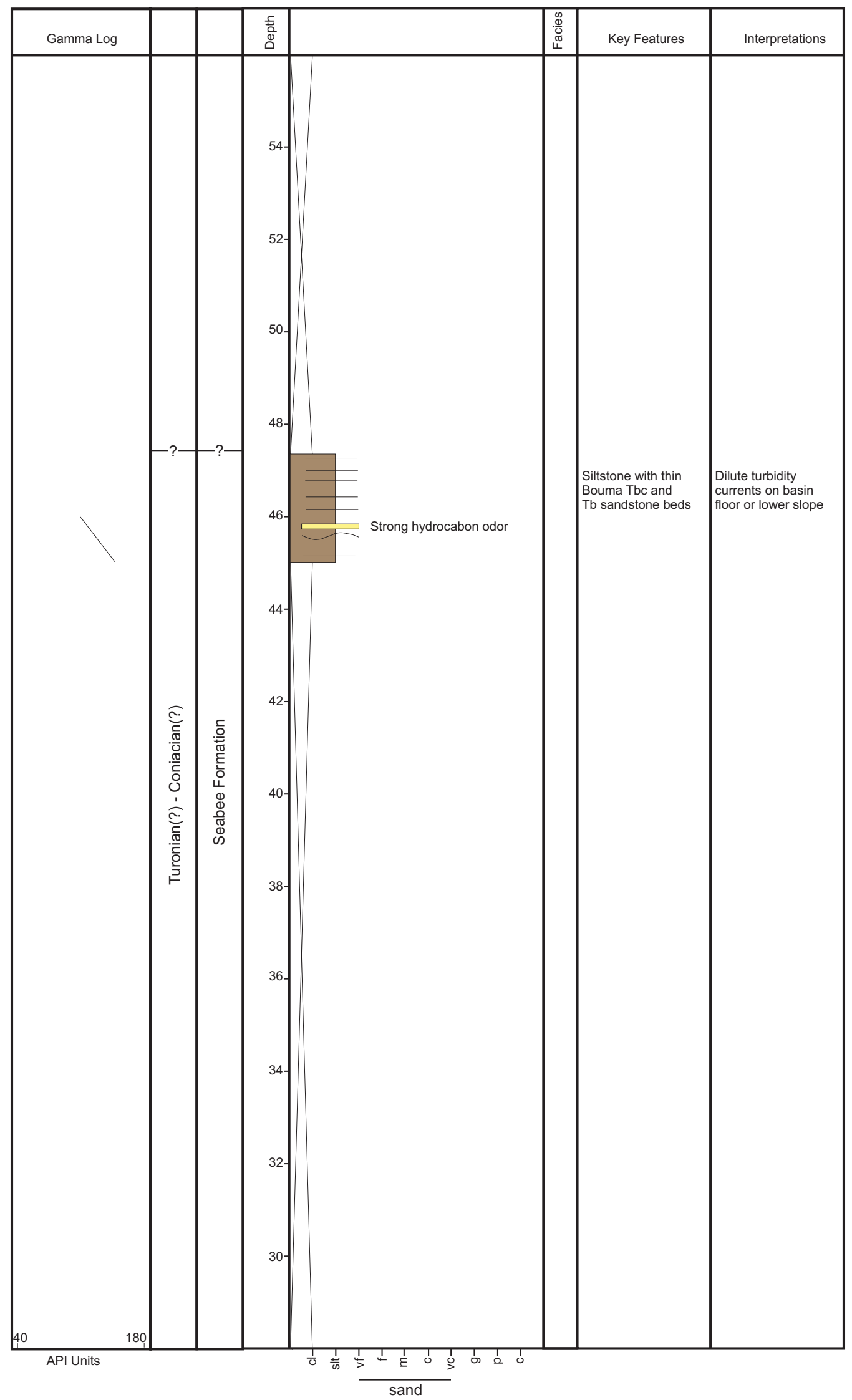

Figure 9. (continued) Measured stratigraphic section through turbidites and associated hemipelagic deposits of the distal Seabee and Canning Formations. Organic-rich clayshale and silicified tuffs above 50 m may represent a tongue of the Hue Shale. See figure 5 (p. 92) for symbol key. 


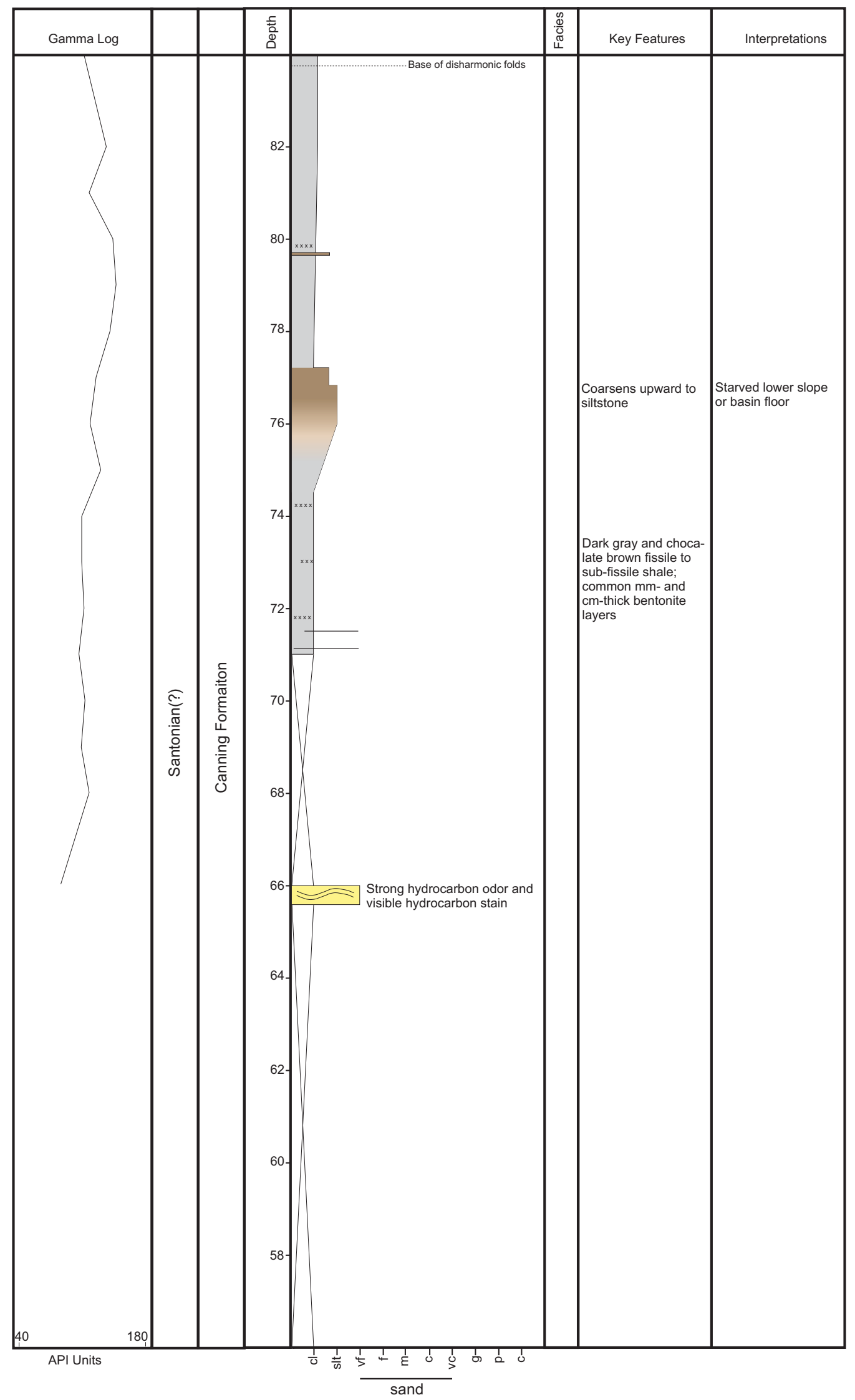

Figure 9. (continued) Measured stratigraphic section through turbidites and associated hemipelagic deposits of the distal Seabee and Canning Formations. Organic-rich clayshale and silicified tuffs above $50 \mathrm{~m}$ may represent a tongue of the Hue Shale. See figure 5 (p. 92) for symbol key. 


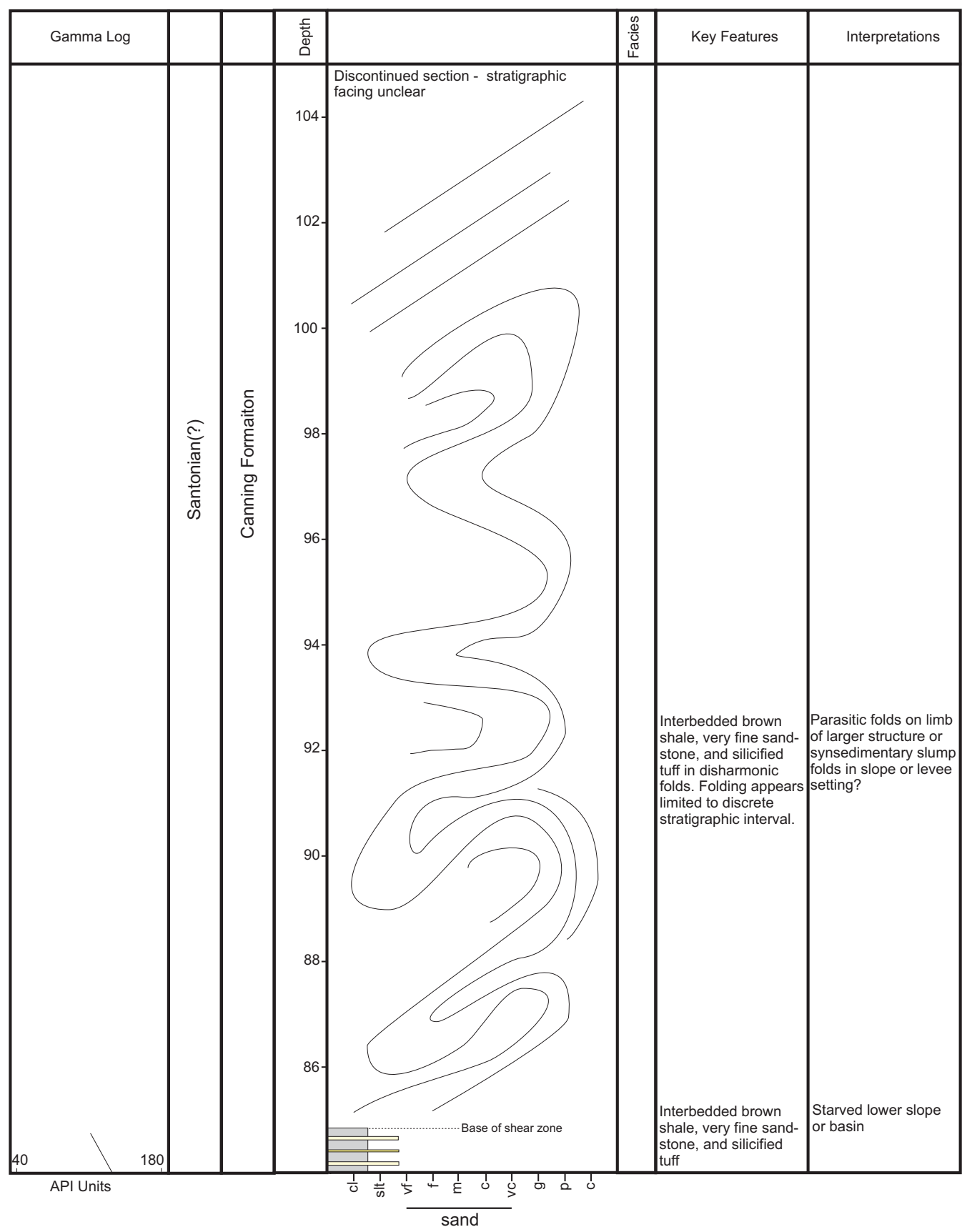

Figure 9. (continued) Measured stratigraphic section through turbidites and associated hemipelagic deposits of the distal Seabee and Canning Formations. Organic-rich clayshale and silicified tuffs above 50 m may represent a tongue of the Hue Shale. See figure 5 (p. 92) for symbol key. 

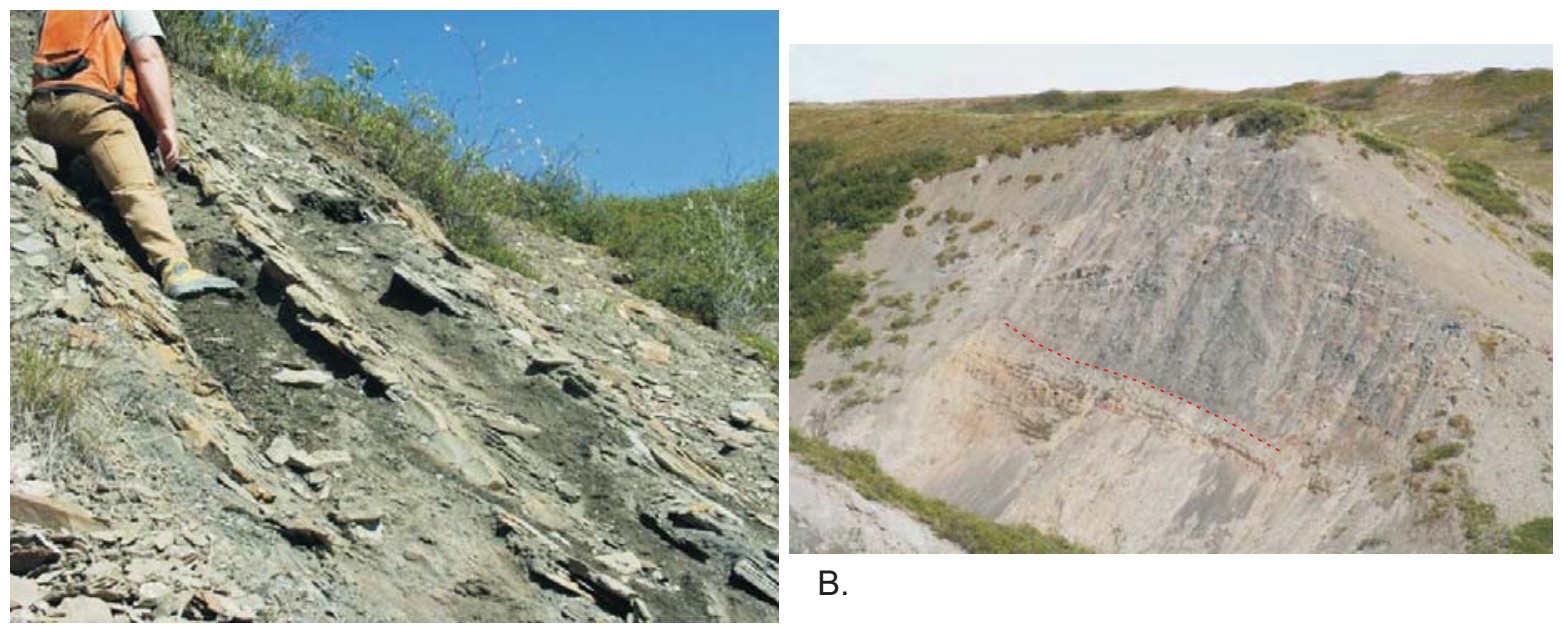

B.

A.

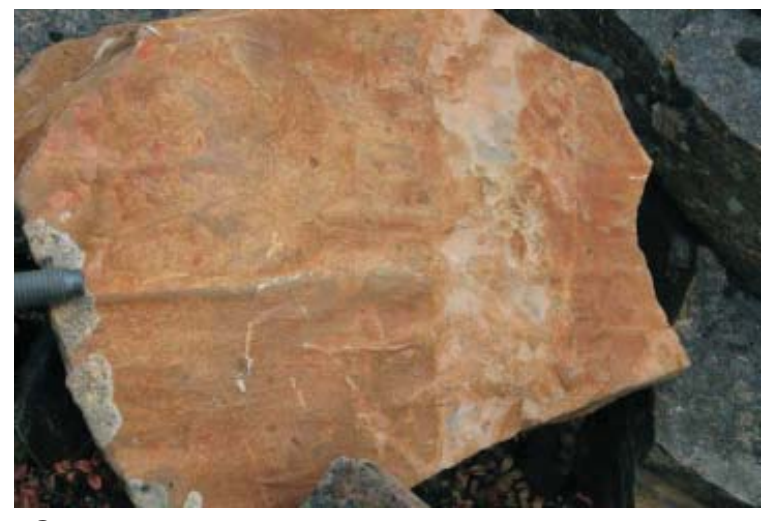

C.

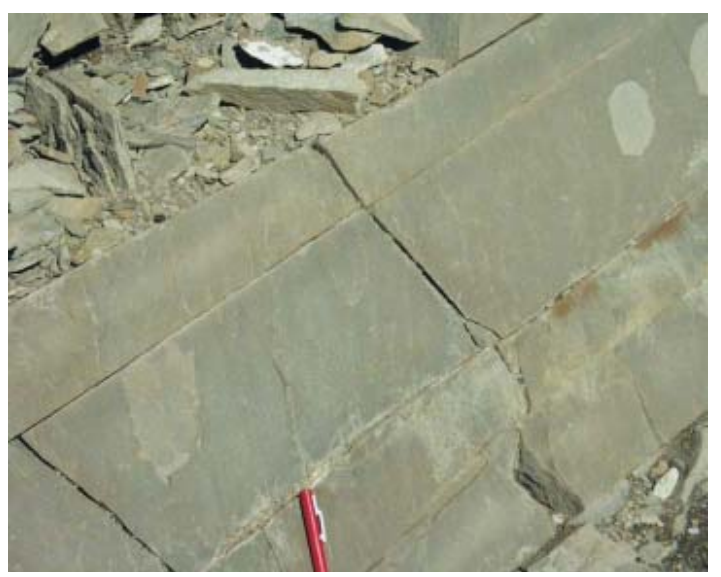

D.
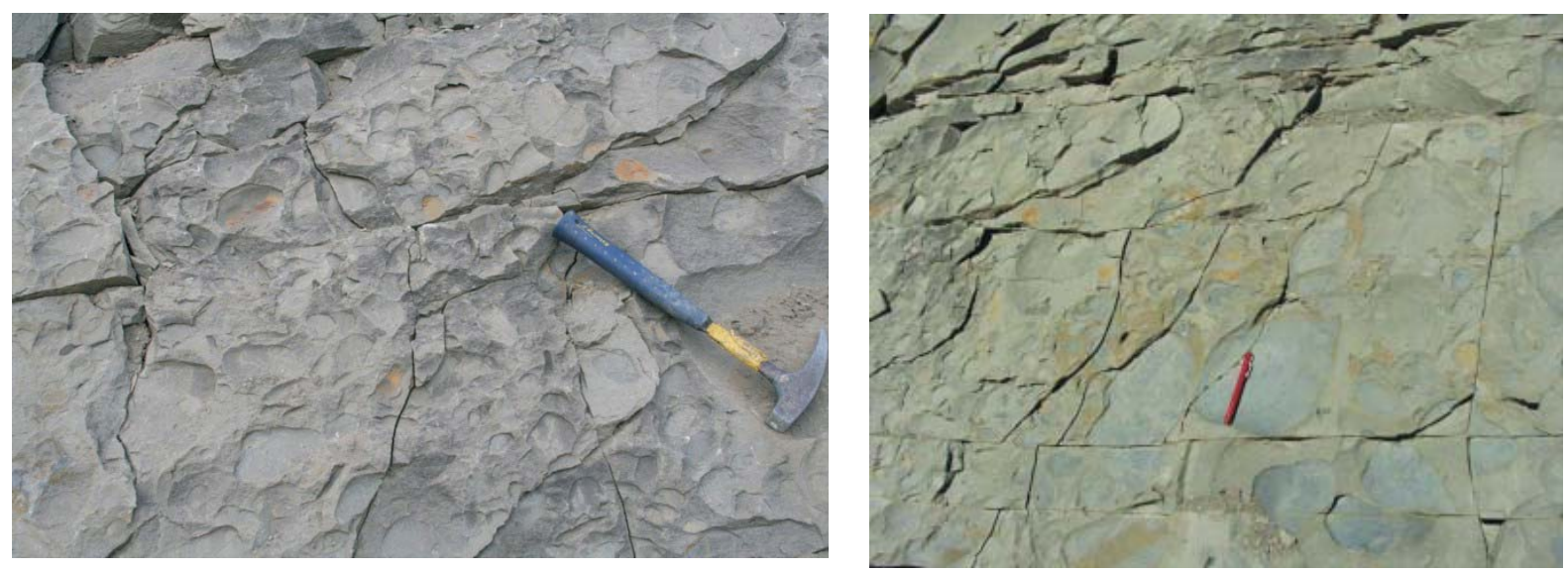

E.

F.

Figure 10 (A-F). Photographs of sedimentary features in turbidites of the distal Seabee and Canning Formations at station 07DL054. (A) Thinly interbedded siltstone, silty shale, and very-fine-grained sandstone. (B) Aerial view toward the east-southeast of disharmonic folds in interbedded clayshale, very-fine-grained sandstone, and silicified tuff between 85 and $104 \mathrm{~m}$. (C) Linear groove cast on sandstone bed near $6 \mathrm{~m}$. (D) Faintly visible flute casts preserved on the upper surface of a sandstone bed at $2 \mathrm{~m}$. These casts were associated with an overlying sandstone bed. Scour at the base of the flow that transported the sand in the overlying bed cut through an intervening thin mudstone bed and into the uppermost portion of the sandstone bed shown here. (E-F) Impressions of mudstone rip-up clasts on a parting surface in a sandstone bed at $20 \mathrm{~m}$. 


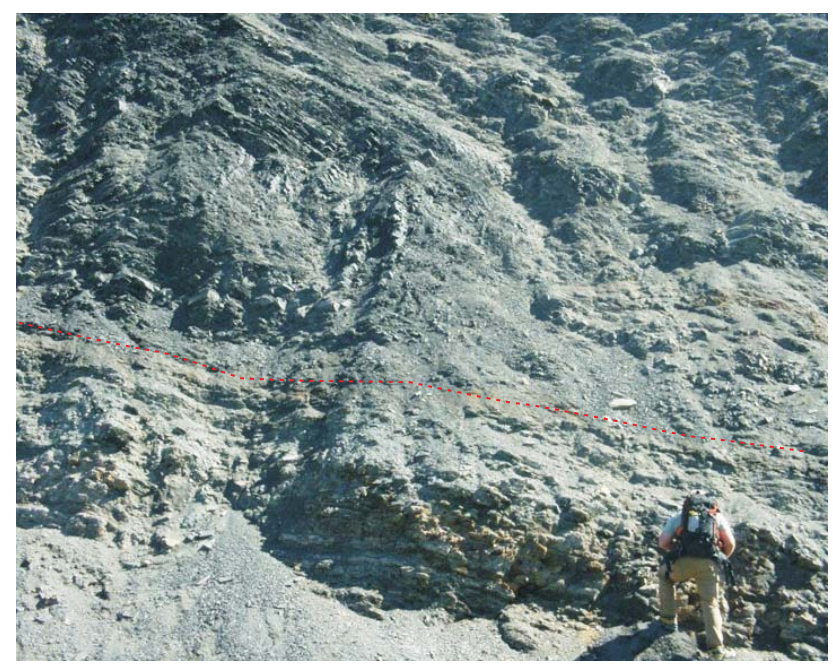

G.

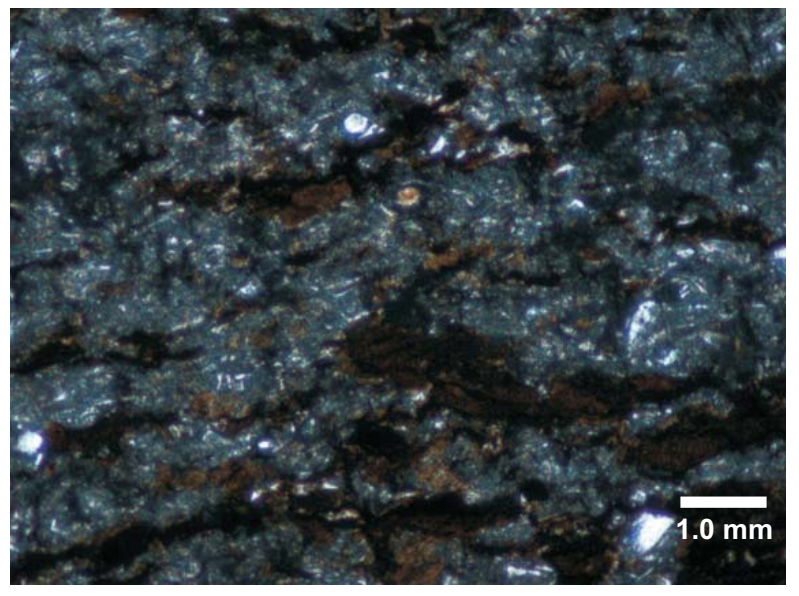

I.

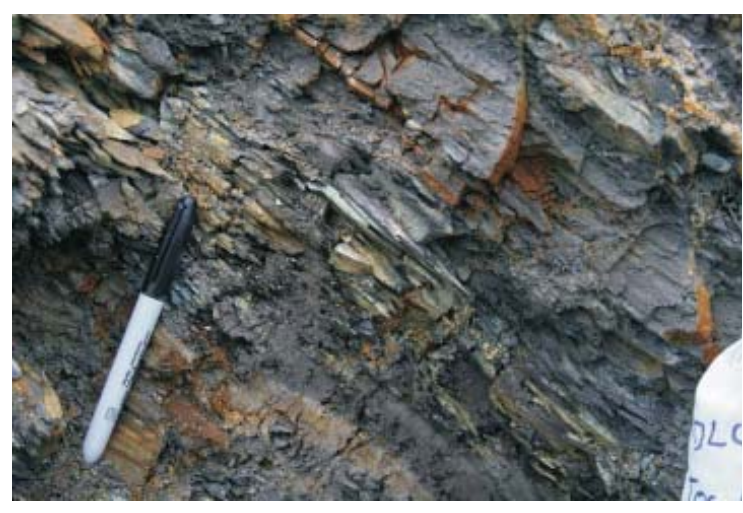

$\mathrm{H}$.

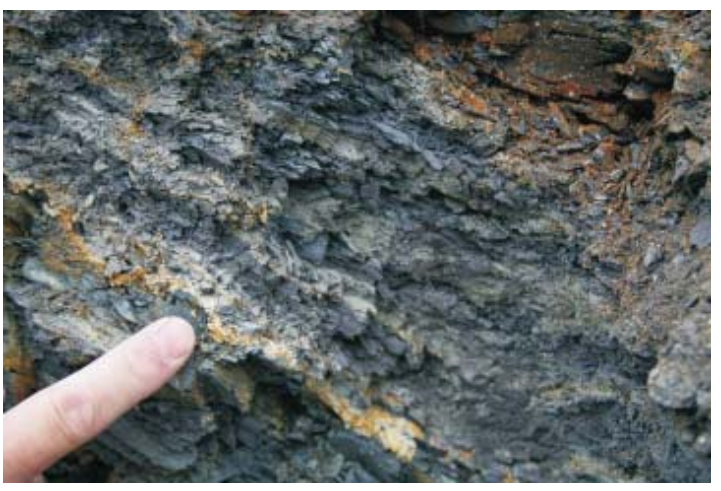

J.

Figure 10 (G-J). Photographs of sedimentary features in turbidites of the distal Seabee and Canning Formations at station 07DL054. (G) Contact between gently dipping interbedded clay shale, very-fine-grained sandstone, and silicified tuffs below and complex folds in overlying strata. The same lithologies comprise the folded package as in the gently dipping succession below. (H) Chocolate brown weathering clayshale at $73 \mathrm{~m}$. (I) Photomicrograph of silicified tuff at $85 \mathrm{~m}$. Some of the dark brown and black opaque material is hydrocarbon. (J) Altered tephra layer at $74.2 \mathrm{~m}$. This is one of many millimeter- to centimeter-thick tephra beds in the upper third of this exposure. Tephras were not observed below $50 \mathrm{~m}$, due to either their absence or to poor exposure.

\section{Station 07DL055}

\section{DESCRIPTION}

Station 055 is located on the north side of the next tributary side valley south of station 054 , immediately east of the main drainage (figs. 2 and 4). Slumped tundra vegetation has exposed approximately 0.5 m of thinly interlaminated siltstone and lower very-fine-grained sandstone. Siltstone is rusty red-brown weathering and dark gray on fresh surfaces and sandstone is present as millimeter-thick laminae.

\section{INTERPRETATION}

Interpretation is not possible given the limited exposure. Available data suggest strata at this location belong to the Canning Formation. 


\section{Station 07DL056 \\ DESCRIPTION}

Station 056 is located at the west end of a prominent east-west-trending ridge characterized by distinctive orange, buff, and light gray weathering float along the ridge crest, north and south flanks, and as talus and steeply south-dipping exposures where the ridge is cut by the main drainage (figs. 2 and 4). Approximately $32 \mathrm{~m}$ of interbedded tuffaceous sandstone, silicified tuff, and slightly silty shale are exposed at the west end of the ridge (figs. 11 and 12a). Two prominent resistant sandstone and tuffaceous packages separated by a thick recessive-weathering interval, dip 48 degrees toward the south. Contact relations between the lower resistant package and underlying strata are poorly known due to talus cover (fig. 12a).

The age of the succession at station 056 is constrained by the Santonian bivalve Sphenoceramus collected near station 056 (Mull, unpublished data) and late Campanian palynomorphs at overlying station 061 (LePain, unpublished data). The age of the succession is probably Santonian to early Campanian.

The lower third of the exposure consists of interbedded shale, tuff, tuffaceous sandstone (reworked tuff?), and minor lime mudstone (figs. 11, 12a, and 12b). Shale is slightly silty, brown to yellow-brown weathering, chocolate brown in fresh cuts, fissile, organic rich(?), and includes few bentonitic layers. Tuff and tuffaceous sandstone are buff to orange weathering, plane-parallel laminated, and locally include well-developed ripple cross-lamination (tuffaceous sandstone). Bed thickness ranges from 1 to $40 \mathrm{~cm}$; thicker beds locally display shard-like fracture patterns. In thin-section, tuffs include needle- and rectangular-shaped crystals within a felted groundmass (fig. 12c). Soft-sediment slump folds are present locally.

The middle third consists of $10 \mathrm{~m}$ of poorly exposed brown weathering sub-fissile shale (figs. 11 and $12 \mathrm{a}$ ). Tuff and tuffaceous sandstone are present in float and it is unclear if these lithologies are present interbedded in the shale.

The upper third consists of rusty brown weathering, sub-fissile silty shale with interbedded buff and orange-buff weathering tuff and tuffaceous sandstone, and minor lime mudstone (figs. 11 and 12d). Shale is similar in appearance to shale encountered in the lower and middle thirds of the exposure. Bedding in tuff, tuffaceous sandstone, and limestone ranges from a few centimeters to $20 \mathrm{~cm}$ thick. Tuff and sandstone appear organized in bedsets up to $70 \mathrm{~cm}$ thick that cap coarsening(?)-upward packages up to $2.5 \mathrm{~m}$ thick. Whitish-yellow bentonite beds up to 15 $\mathrm{cm}$ thick are interbedded within the silty shale. Lime mudstone is a minor component that weathers rusty brown, is dark brown on fresh surfaces, and has a distinct hydrocarbon odor.

\section{INTERPRETATION}

Organic-rich(?) brown shale suggests deposition in a deep-water setting below the oxygen minimum layer. Interbedded tuffs and bentonites originated from volcanic eruptions as airfall deposits that settled through the water column (submarine ashfalls). Ripple cross-laminae indicate that some tuffs were reworked during or after deposition on the sea floor. Meter-scale coarsening-upward successions could record deposition on levees marginal to active channels and, if correctly interpreted, indicate at least some reworking. Minor but conspicuous smallscale slump folds in tuffs are consistent with deposition in levee or slope settings. Given available data, choosing between these possibilities is not possible.

Strata at this station are assigned to the Canning Formation. Based on the resistant tuffaceous character and the likely Santonian-early Campanian age, strata at this location are tentatively correlated with the Barrow Trail Member (Schrader Bluff Formation) of former usage, which is exposed in the Umiat Quadrangle west of the Trans-Alaska pipeline corridor (Whittington, 1956). The age-diagnostic inoceramid Sphenoceramus (Santonian) was collected down-section (northwest) between stations 55 and 56. Sphenoceramus is common in the Barrow Trail Member in outcrop to the west (Brosgé and Whittington, 1966, p. 547). Other megafossils from the Barrow Trail Member indicate a middle Santonian to early Campanian age (Brosgé and Whittington, 1966).

Wartes (oral commun.) suggested correlating silicified tuffaceous strata at station 056 with the middle part of the Hue Shale, which was described in outcrop (south side of Ignek Valley) and recognized in core from the West Staines 18-9-23 well (south of Point Thomson; Molenaar and others, 1987, p. 521; fig. 1). Palynological data from the West Staines well indicate a Santonian-Campanian age (Molenaar and others, 1987).

\section{Station 07DL057 \\ DESCRIPTION}

Station 057 is an inconspicuous tundra-covered slope with float of chippy shale and siltstone between grass tussocks (figs. 2 and 4). 
07DL056

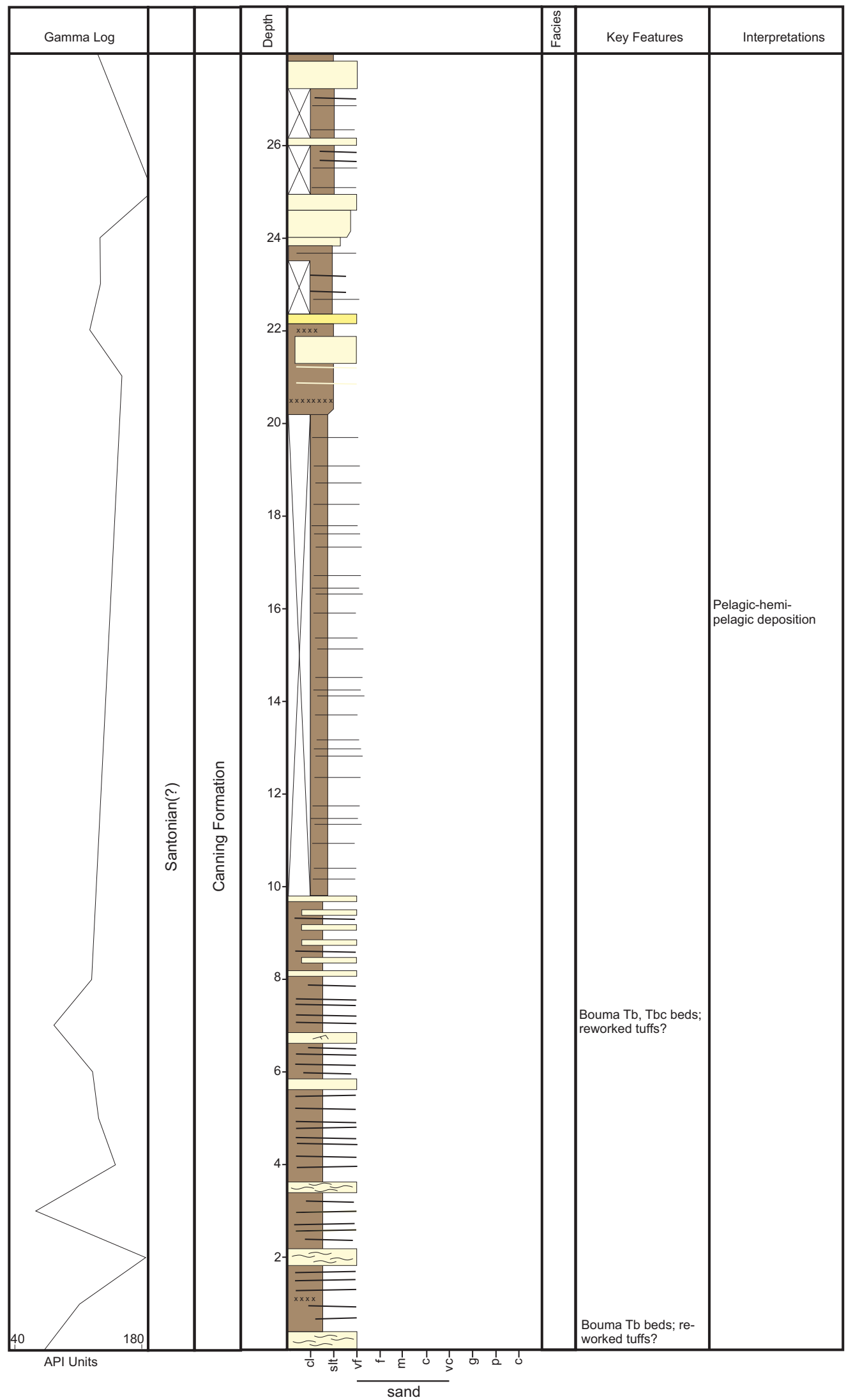

Figure 11. Measured stratigraphic section through probable Santonian age distal turbidites and associated hemipelagic deposits of the Canning Formation at station 07DL056. See figure 5 (p. 92) for symbol key. 


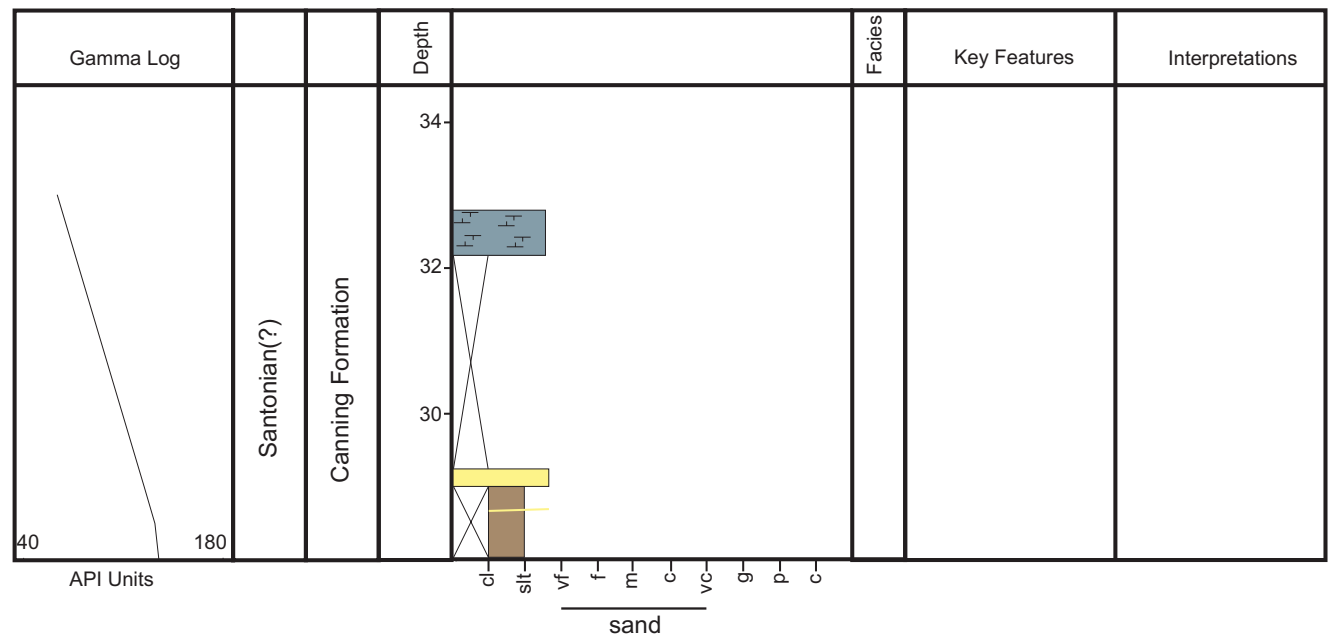

Figure 11. (continued) Measured stratigraphic section through probable Santonian age distal turbidites and associated hemipelagic deposits of the Canning Formation at station 07DL056. See figure 5 ( $p$. 92) for symbol key.

\section{INTERPRETATION}

Interpretation is not possible given the limited exposure.

\section{Station 07DL058}

\section{DESCRIPTION}

Station 058 is the first prominent east-west-trending ridge south of station 056 (figs. 2 and 4) and consists of approximately $3 \mathrm{~m}$ of amalgamated buff to light gray weathering very-fine- to fine-grained sandstone. Beds dip 26 degrees toward the southwest and are 15-50 cm thick in the lower $2 \mathrm{~m}$ and $1-5 \mathrm{~cm}$ thick in the upper meter. Common concave-up scour surfaces are overlain by gently-dipping laminae. Small-scale trough cross-bedding is visible locally (Bouma Tc?) as are low-relief asymmetric current-ripple bedforms. Bedform crestlines are discontinuous and parallel, and the lee face associated with one bedform dips toward 155 degrees (corrected for tectonic tilt). Mudstone rip-up impressions are common and typically concentrated along cryptic scour surfaces. Load casts are prominent features on the underside of some sandstone beds (fig. 12e), yet interbedded mudstone is not evident. White mica is a prominent, but minor, component of these sandstones and small carbonaceous plant fragments are present on some bed surfaces.

\section{INTERPRETATION}

Features observed in sandstone at this location could form in a variety of shallow- and deep-water settings. Given the stratigraphic position of these strata above basin-floor or slope deposits at station 056 and below probable slope facies at station 063 (described below), a depositional setting basinward of the coeval shelf edge is likely.

\section{Station 07DL059}

\section{DESCRIPTION}

Station 059 (figs. 2 and 4) consists of a stream of float approximately $8 \mathrm{~m}$ wide with about $30 \mathrm{~cm}$ of thin flaggy parting sandstone in place (fig. 12f). Sandstone is light gray to buff weathering, lighter gray on fresh surfaces, and coarse grained. A shallow excavation exposed thinly interbedded sandstone and siltstone. Plane-parallel lamination (Bouma $\mathrm{Tb}$ ) is common in sandstones and one thin sandstone bed within the excavation included small groove casts on its basal surface. Parting lineation is common on sandstones in float.

\section{INTERPRETATION}

Parting lineation and plane-parallel lamination are consistent with deposition from dilute turbidity currents under upper flow-regime plane-bed conditions as Bouma Tb beds. A deep-water depositional setting is inferred by the stratigraphic context of this exposure below interpreted slope strata and above interpreted slope to basin-floor deposits. Assigning this exposure to a deep-water architectural element (in the sense of Mutti and Normark, 1987) 


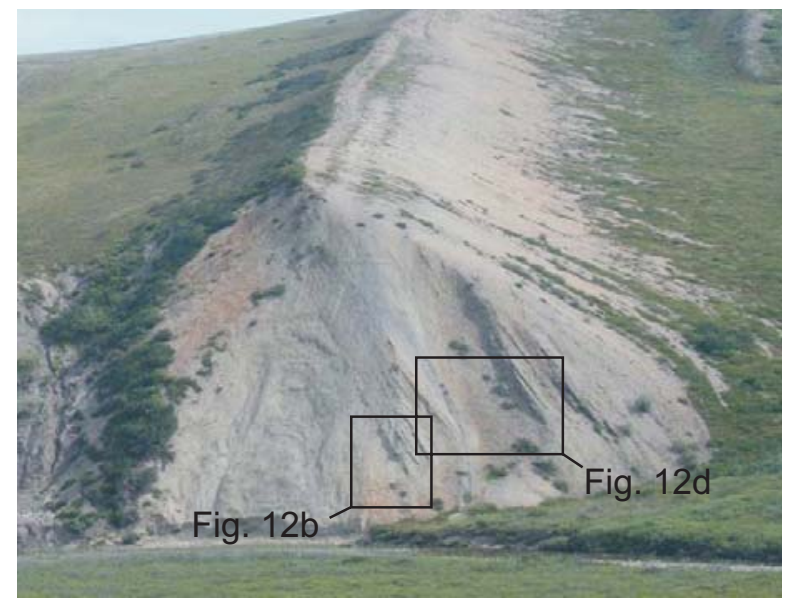

A.

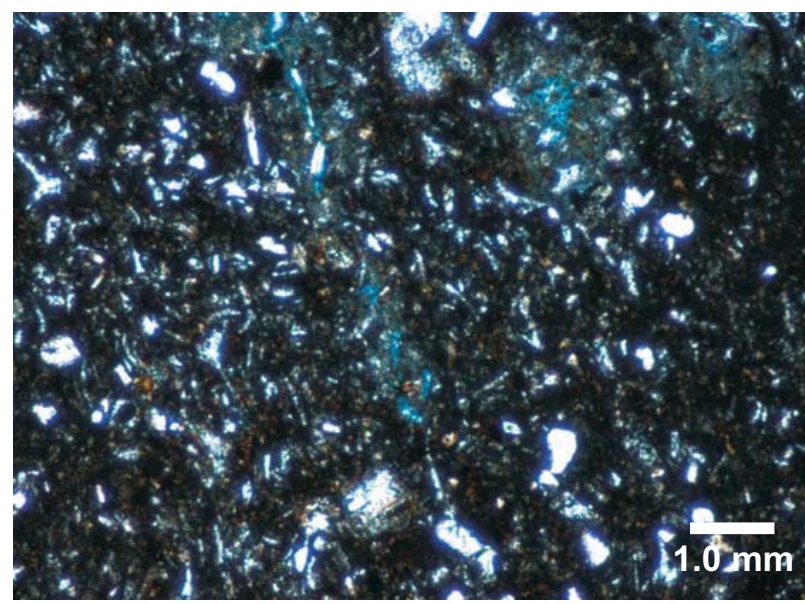

C.

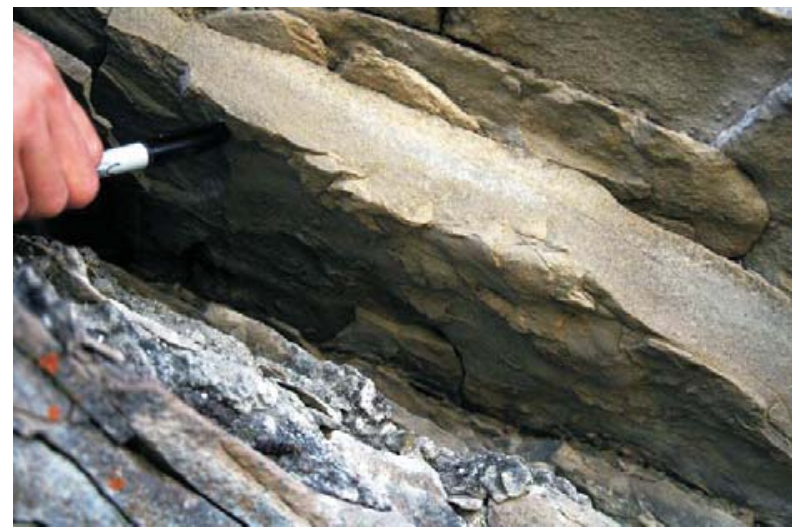

E.

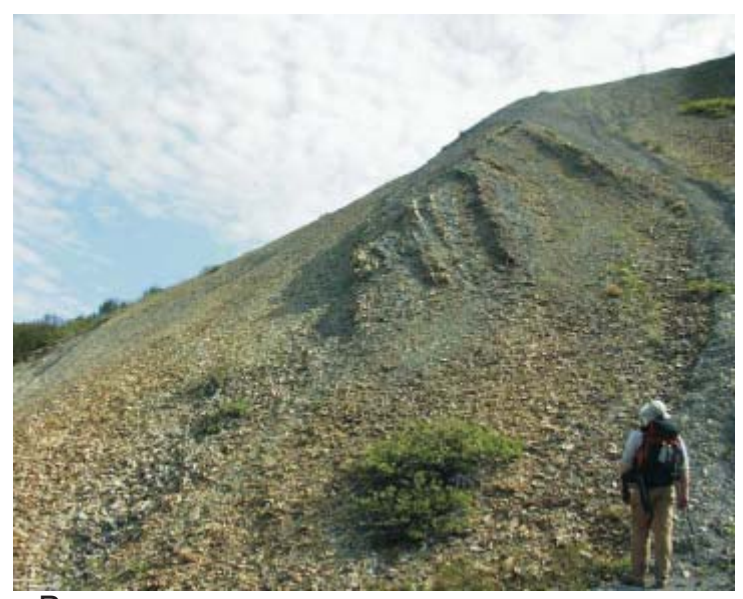

B.

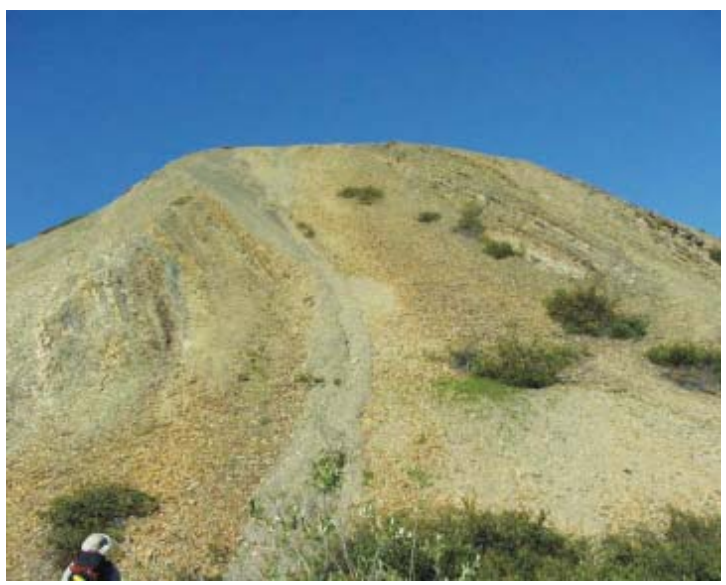

D.

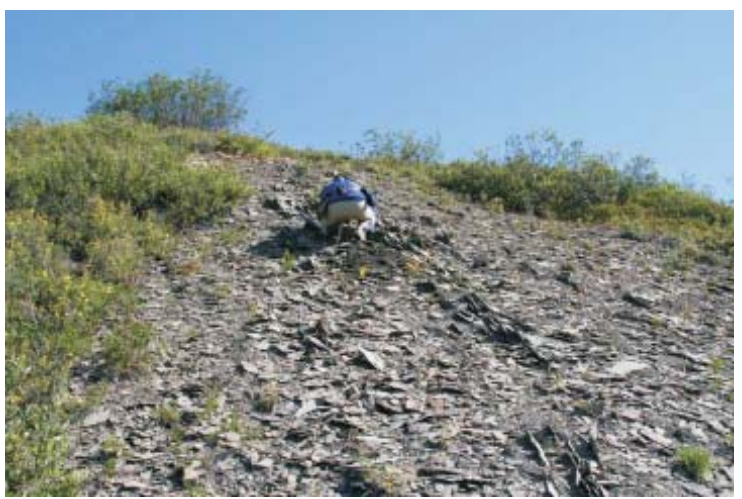

F.

Figure 12. Photographs of sedimentary features in probable Santonian strata of the Canning Formation at stations 07DL056, 07DL058, and 07DL059. (A) Aerial view toward the northeast showing rubblecrop and exposures of tuffaceous(?) sandstones and interbedded silty clayshale and tephra at station 07DL056. Abundant volcanigenic material in these rocks imparts the light buff to orange-brown color typical of sandstones at this station. (B) Outcrop of thin-bedded sandstone and interbedded silty clayshale and tephra in the lower $10 \mathrm{~m}$ of the measured section at 07DL056. (C) Photomicrograph of silicified tuff at approximately $9 \mathrm{~m}$ in the measured section at 07DL056. (D) Outcrop of interbedded thin-bedded sandstone and silty clayshale in the upper third of the measured section at station 07DL056. (E) Load casts on the underside of a sandstone bed in rubblecrop at station 07DL058. (F) Thin flaggy parting sandstone in rubblecrop at station 07DL059. 
is not possible given the limited exposure. Coarse-grained sandstone represents a significant grain size increase over the very-fine- to fine-grained sandstones down-section. Whatever depositional element these rocks are part of, significantly coarser sediment was being supplied to the depositional system, possibly from nearby shelf-edge (late highstand or lowstand) deltas. Taken in the context of station 061, coarse-grained sandstones at this location are interpreted as late highstand deposits.

\section{Station 07DL060 \\ DESCRIPTION}

Station 060 (figs. 2 and 4) consists of a few meters of buff weathering medium-grained sandstone that barely protrudes from the tundra cover. Bedding dips 55 degrees toward the south.

\section{INTERPRETATION}

Interpretation is not possible given the limited extent of exposure. Whatever depositional element these rocks are part of, as at the previous station, significantly coarser sediment was being supplied to the depositional system, possibly from nearby shelf-edge (late highstand?) deltas.

\section{Station 07DL061}

\section{DESCRIPTION}

Station 061 is a prominent exposure near river level consisting of $60 \mathrm{~m}$ of interbedded siltstone, sandstone, and minor conglomerate dipping 43 degrees toward the south (figs. 2, 4, 13, and 14a).The lower half is continuously exposed, whereas the upper half is mostly covered interval with localized exposures of resistant sandstone and conglomerate.

The age of this succession is constrained by microfossils. A probable Turonian to Santonian age range is suggested by foraminifera and a late Campanian age is indicated by palynomorphs. The age of the section is probably Campanian.

The lower $25 \mathrm{~m}$ consists of interbedded sandstone and siltstone organized in a series of prominent coarsening- and thickening-upward (CU-TU) cycles approximately 1.5-4 m thick (figs. 13 and 14b). Sandstones are buff weathering, medium to light gray on fresh surfaces, and very fine to fine grained. Siltstone is light gray weathering, medium to dark gray on fresh surfaces, and parts in small platy pieces. Bed thickness ranges from $>3 \mathrm{~cm}$ in siltstone and sandstone near the base of CU-TU cycles to $25 \mathrm{~cm}$ in sandstone near the top. Thin silty partings separate sandstone beds at the top of some CU-TU cycles, whereas amalgamated sandstones cap others. Sole markings are common and include bulbous-shaped load casts and flute casts (figs. 14c and 14d). Flute casts commonly appear load-enhanced. Mudstone rip-up clasts are common on some bed surfaces. Bouma Tabc, Tb, and Tbc beds are common. Where present, the Ta division of beds is subtle (fig. 14e). Small- to moderate-scale two- and three-dimensional (linguoid) current ripple bedforms cover some bed surfaces (wavelength $10-20 \mathrm{~cm}$ and amplitude 1-3 cm) (figs. 14f and 14g). Terrestrial plant material is common in sandstones and occurs as streaks of finely divided plant material concentrated in selected laminae, as finely divided carbonaceous remains scattered on bed surfaces, concentrated as "coffee grounds" in the lee of current ripple bedforms (fig. 14h), and as large impressions of woody and leafy material densely covering some bed surfaces (fig. 14i). Trace fossils appear absent throughout the succession. At least one sandstone bed is cut by a small-scale, northwest-vergent thrust fault (fig. 14j).

The upper $35 \mathrm{~m}$ is a poorly exposed succession of siltstone with resistant thinly to thickly interbedded veryfine- to coarse-grained sandstone and pebble conglomerate. Siltstone successions range from 3 to $8.5 \mathrm{~m}$ thick and, where exposed, include chippy light- to medium-gray weathering material that is dark gray on fresh surfaces. Sandstone is orange-brown, light brown, and buff-weathering and light brown or gray on fresh surfaces. White and aquamarine colored grains of chert are distinctive framework components when viewed on fresh surfaces. Load and flute casts are common on the base of sandstone beds and provide robust way-up indicators (fig. 14k). Sandstones commonly appear massive and size grading has not been recognized. Concave-up surfaces suggestive of trough cross-bedding and current ripple cross-lamination are prominent locally. Parting lineations and finely divided organic debris are present on many bed surfaces.

Two thin but prominent conglomerate beds, each up to $40 \mathrm{~cm}$ thick, are separated by a medium- to coarsegrained sandstone bed $50 \mathrm{~cm}$ thick (fig. 14l). Conglomerates are poorly sorted, clast-supported, polymictic, and include tightly packed matrix material of fine- to coarse-grained sandstone. Clasts include extrabasinal and intrabasinal varieties. Extrabasinal clasts are up to $7 \mathrm{~cm}$ in apparent long dimension, are dominantly equant shaped, and include black, gray, and white chert, cherty(?) argillite, and white vein quartz. Intrabasinal clasts up to $14 \mathrm{~cm}$ in apparent long dimension are dominantly disc-shaped and overwhelmingly consist of orange weathering sideritized(?) mudstone. Disc-shaped clasts commonly display bed-parallel to weak imbricate fabrics (fig. $14 \mathrm{~m}$ ). The 


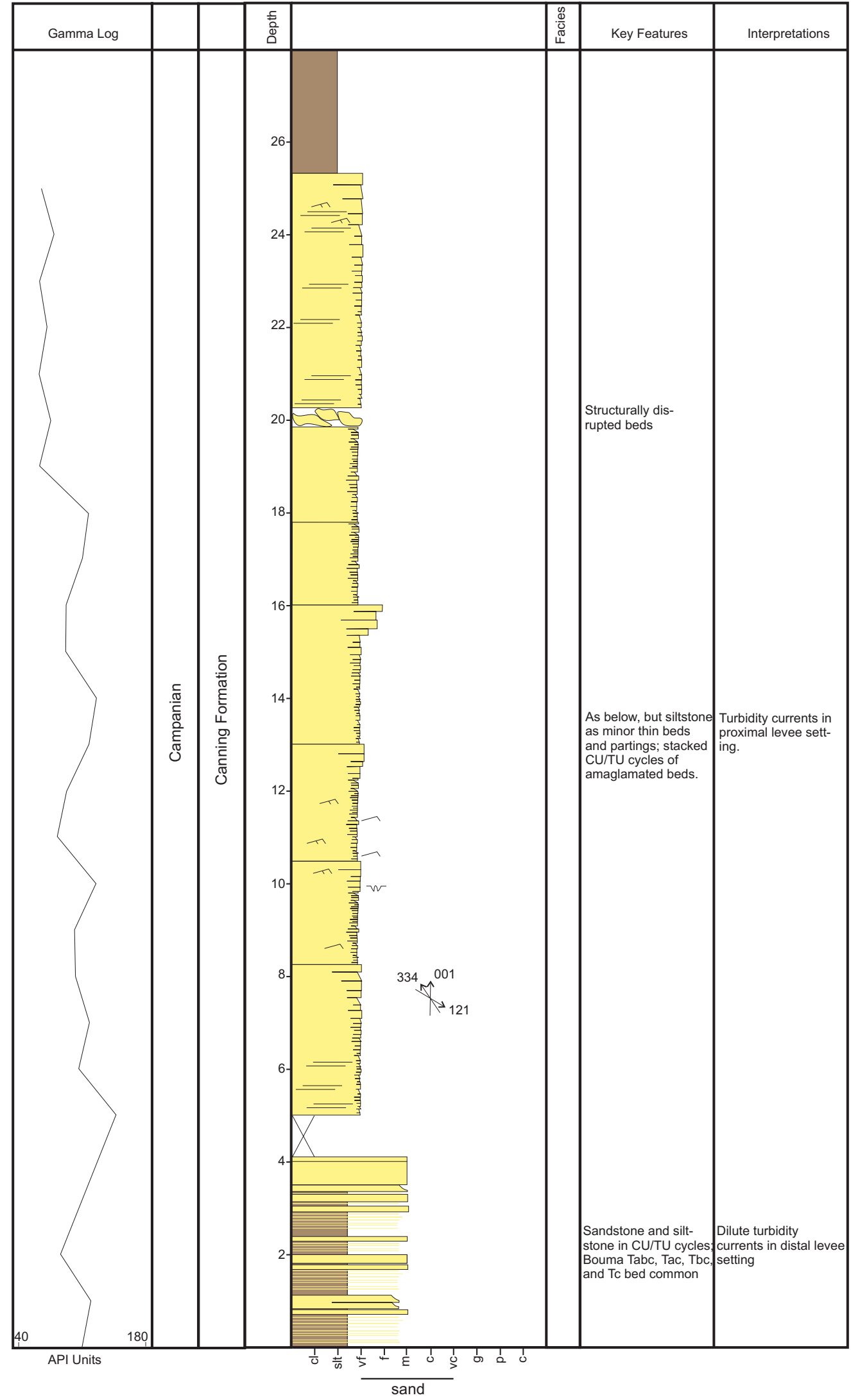

Figure 13. Measured stratigraphic section through Campanian age base-of-slope to proximal basin-floor turbidites and associated deposits of the Canning Formation at station 07DL061. See figure 5 (p. 92) for symbol key. 


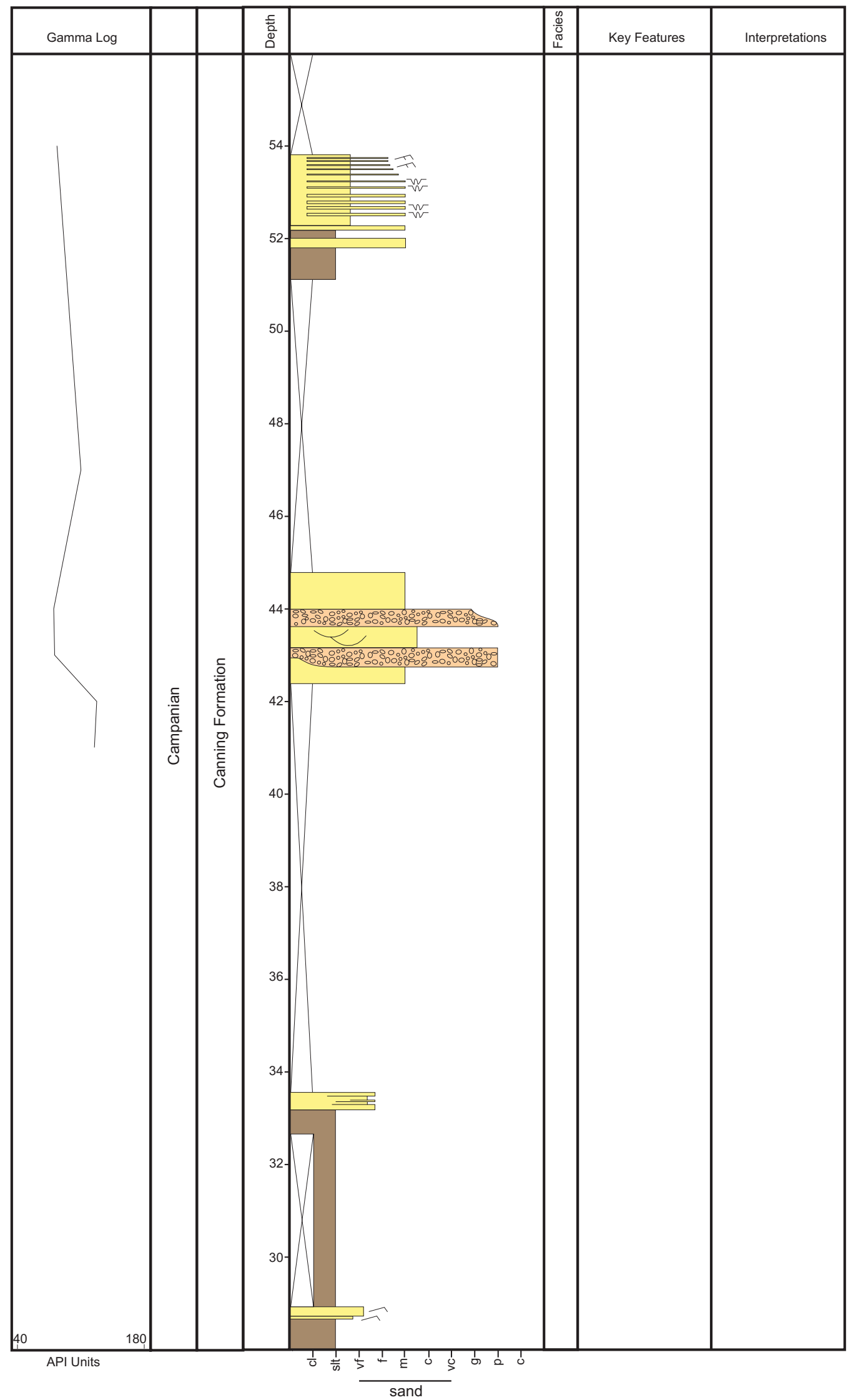

Figure 13. (continued) Measured stratigraphic section through Campanian age base-of-slope to proximal basin-floor turbidites and associated deposits of the Canning Formation at station 07DL061. See figure 5 (p. 92) for symbol key. 


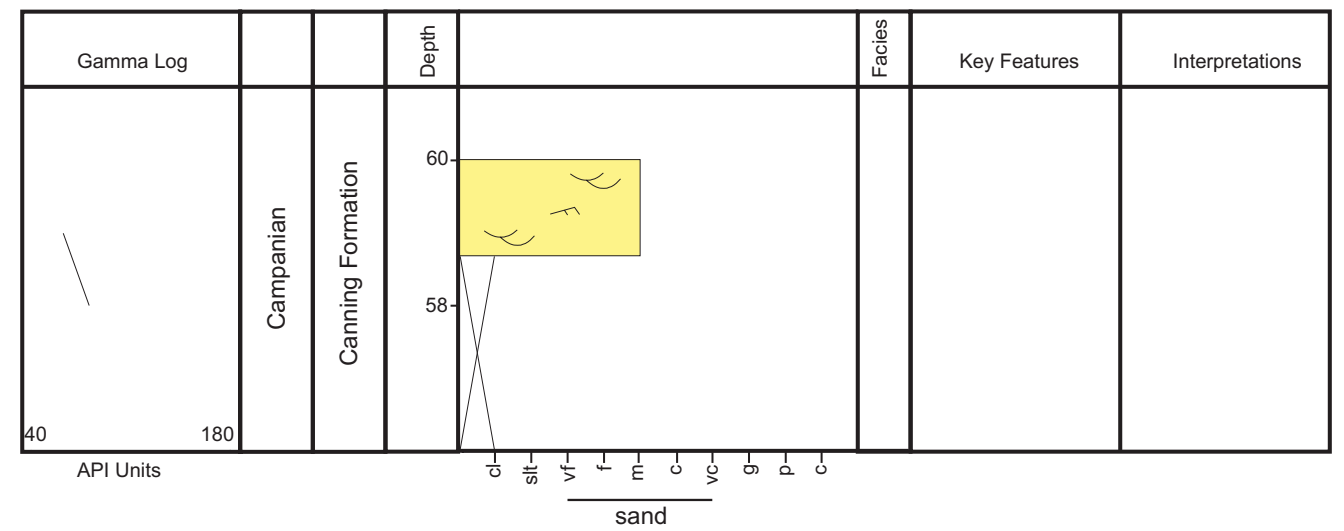

Figure 13. (continued) Measured stratigraphic section through Campanian age base-of-slope to proximal basin-floor turbidites and associated deposits of the Canning Formation at station 07DL061. See figure 5 (p. 92) for symbol key.

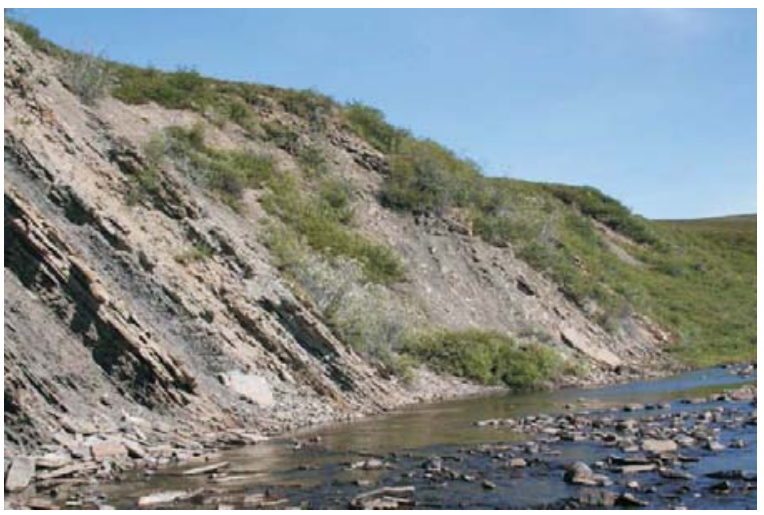

A.

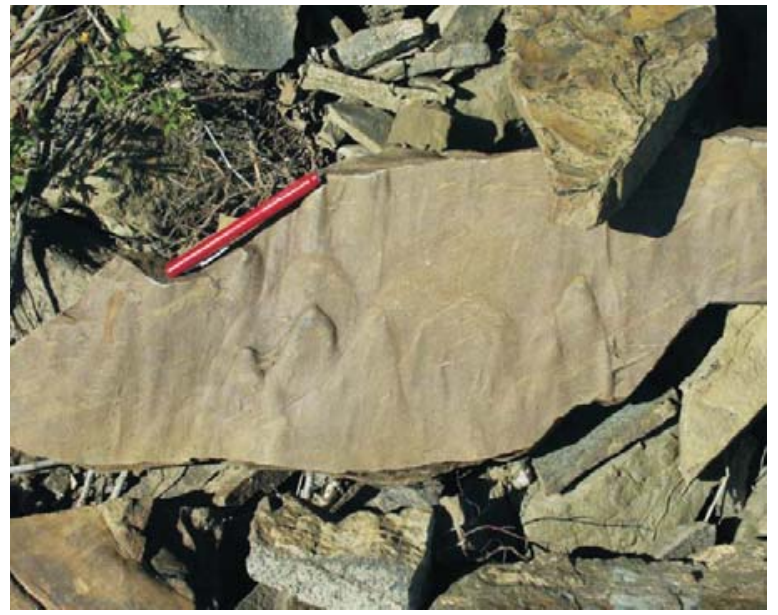

C.

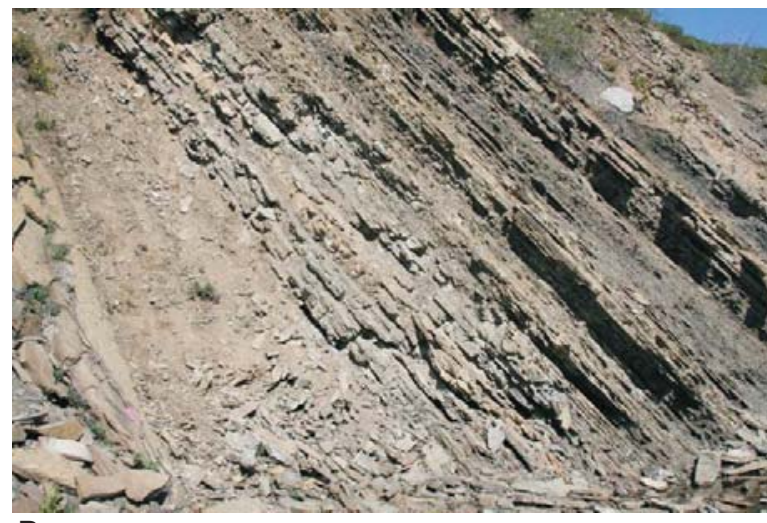

B.

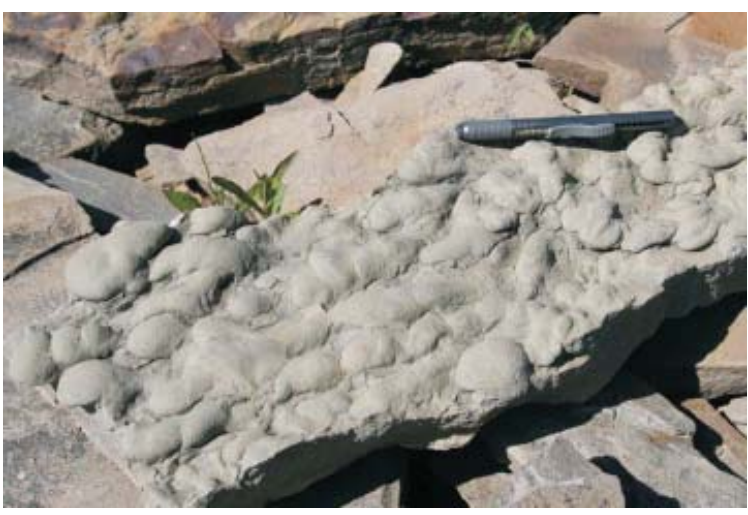

D.

Figure 14 (A-D). Photographs of sedimentary features in Campanian strata of the Canning Formation at station 07DL061. (A) View toward the east-southeast showing interbedded sandstone and mudstone between 16 and $25 \mathrm{~m}$ of the measured section (left half of photograph); the partially vegetated slope in the middle distance corresponds to 25-42 $\mathrm{m}$ in the measured section; the resistant beds in right third of the image are sandstone and conglomerates between 42.5 and $60 \mathrm{~m}$.

(B) Interbedded sandstone and siltstone between 2 and $10 \mathrm{~m}$ showing meter-scale coarsening-and thickening-upward cycles interpreted as levee deposits marginal to a submarine channel. (C) Flute casts on a piece of sandstone float near $8 \mathrm{~m}$. (D) Bulbous load casts in float in the lower $4 \mathrm{~m}$ of the measured section. 


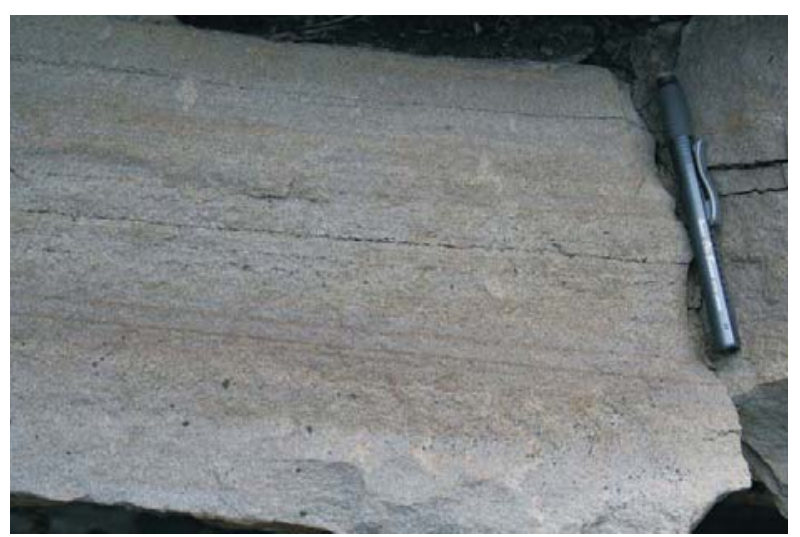

E.

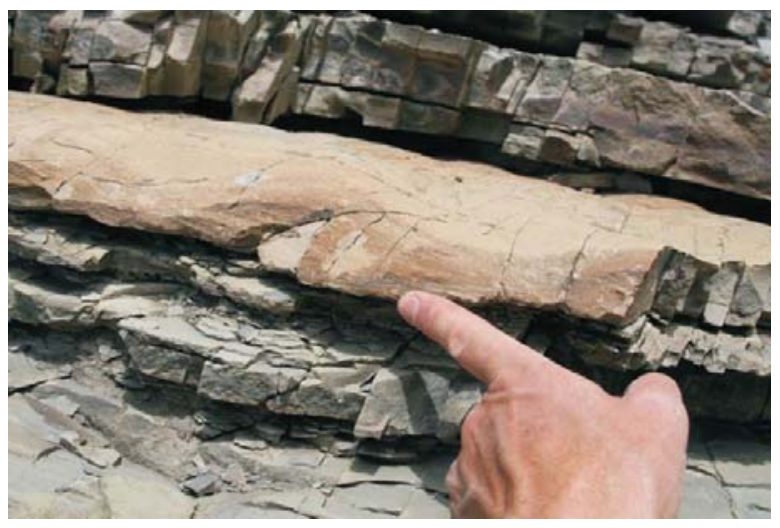

G.
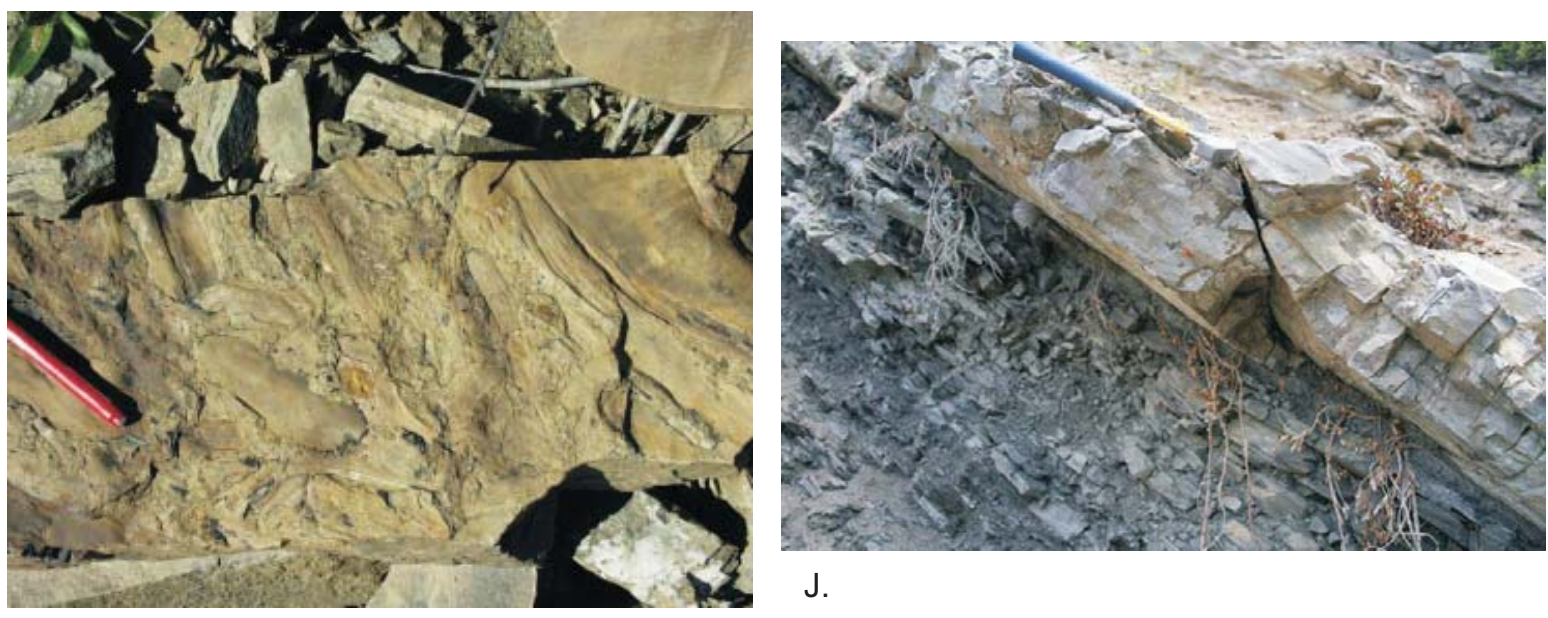

J.

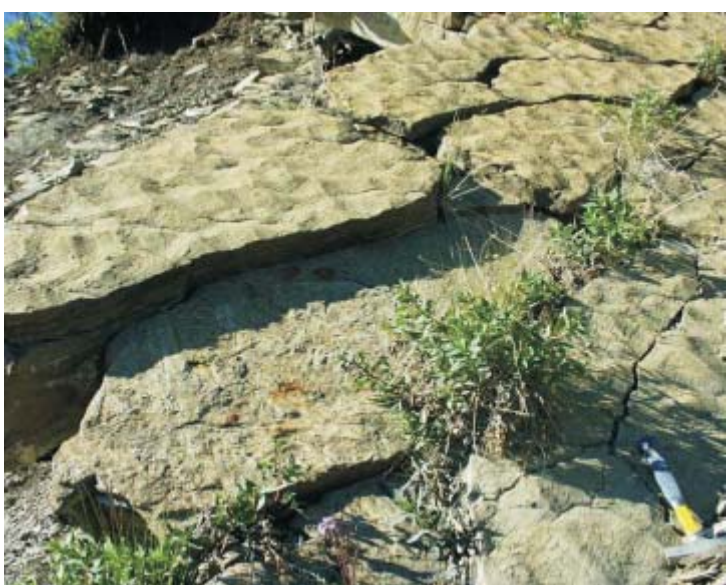

F.

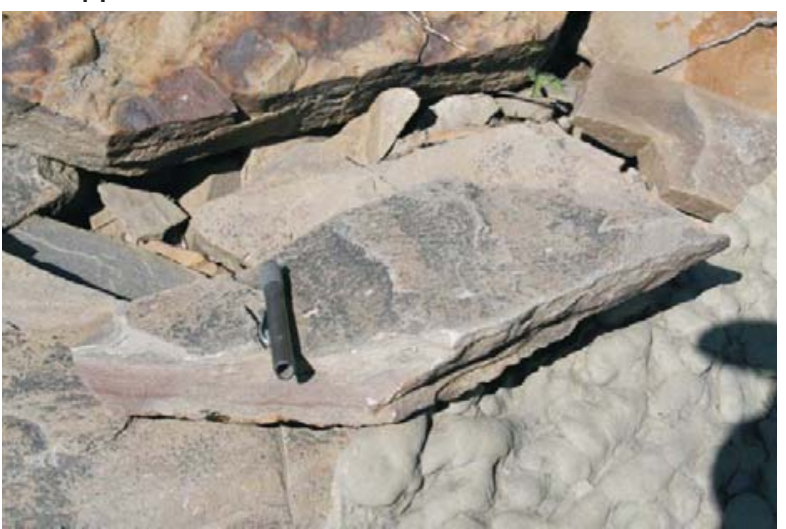

$\mathrm{H}$.

I.

Figure 14 (E-J). Photographs of sedimentary features in Campanian strata of the Canning Formation at station $07 D L 061$.

(E) Bouma Tab bed at $6 \mathrm{~m}$. (F-H) Small-scale three-dimensional to slightly sinuous-crested two-dimensional ripple bedforms on sandstone bed surfaces between 8 and $12 \mathrm{~m}$. (I) Large woody and leafy plant impressions on bed surface between 3 and $4 \mathrm{~m}$. (J) Small-scale thrust fault at $20 \mathrm{~m}$. 


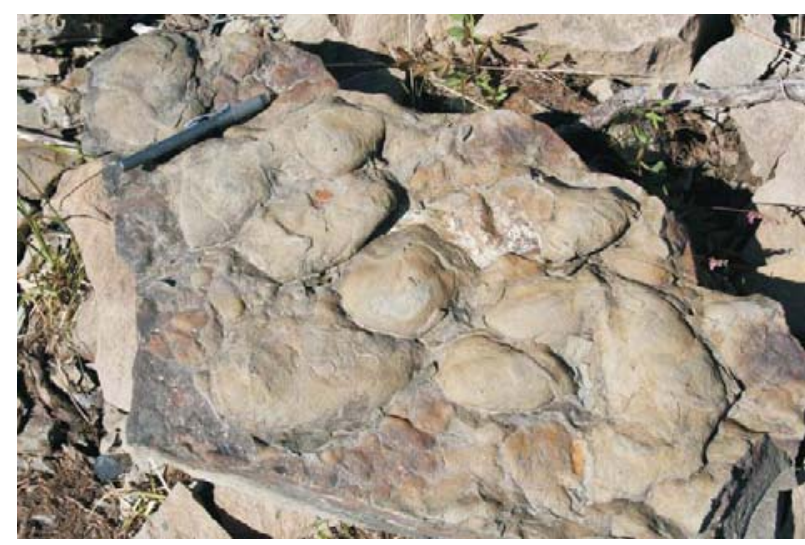

$\mathrm{K}$.

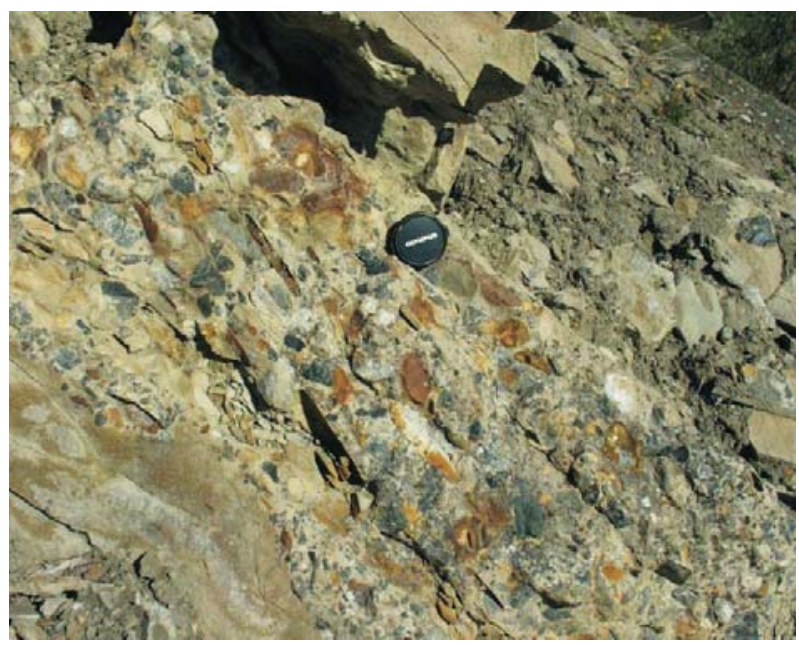

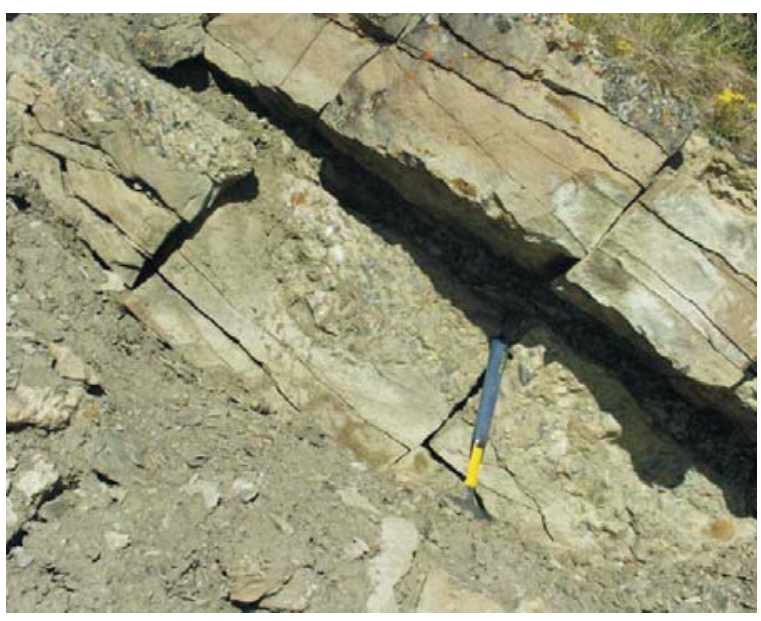

L.

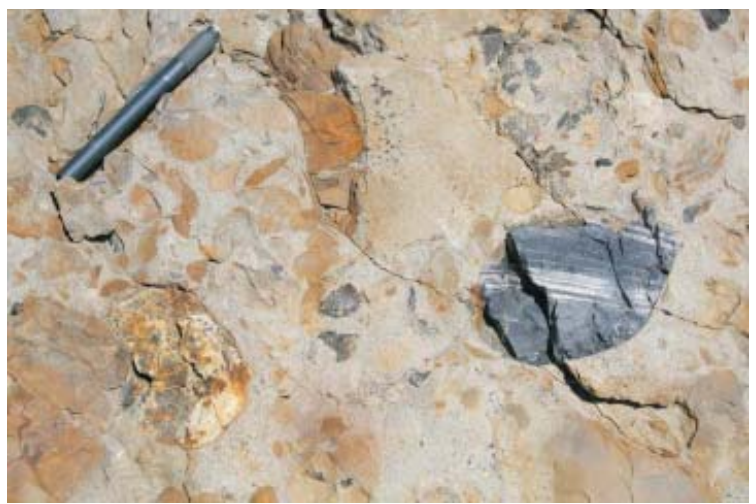

N.

M.

Figure 14 (K-N). Photographs of sedimentary features in Campanian strata of the Canning Formation at station 07DL061. (K) Load casts on underside of sandstone bed in float in the upper $35 \mathrm{~m}$ of the measured section. Load casts are common in this part of the succession. (L) Two poorly-sorted, clast-supported pebble conglomerate beds. The hammer handle rests on the lower bed at $43 \mathrm{~m}$. The base of the upper bed is visible in the upper right corner of the photograph. (M) Clast fabric in bed at $43 \mathrm{~m}$. Note preferred alignment of discoid clasts. Disc-shaped clasts are most commonly sideritized mudstone rip-ups. (N) Clasts of sideritized mudstone (orange), cherty(?) argillite (black clast with white laminae), and rare silicified tuff clasts that are outwardly similar to tuffs at station 07DL054 (84-85 m).

clast population includes rare tuff or brown shale clasts (fig. 14n) similar to lithologies encountered at stations 054 and 056. The contact between conglomerates and underlying sandstones is sharp and erosive, with up to $20 \mathrm{~cm}$ of erosional relief. Both conglomerate beds can be traced up the slope toward the east approximately $15 \mathrm{~m}$ until the beds become concealed by tundra cover.

\section{INTERPRETATION}

Thinly interbedded sandstone and siltstone, organized in prominent thickening- and coarsening-upward cycles, resemble levee deposits described by Mutti and Normark (1987) and Weimer and Slatt (2007) and are similarly interpreted. The abrupt change from interbedded sandstone and siltstone in the lower part of the exposure to poorly exposed siltstone with few interbeds and bedsets of sandstone and conglomerate suggest a fundamental change in the depositional pattern, which can be interpreted in several different ways. This part of the succession could record deposition in a channelized or gullied lower slope setting, or deposition in a channelized lobe setting. The low sandstone content argues against the latter setting. The abrupt introduction of conglomeratic material suggests 
deposition during a lowstand of relative sea level.

Available biostratigraphic data suggest correlation with the Schrader Bluff Formation west of the Trans-Alaska pipeline corridor.

\section{Station 07DL062 \\ DESCRIPTION}

Station 062 is a small, inconspicuous exposure a short distance southeast of station 061 (figs. 2 and 4). Approximately $1 \mathrm{~m}$ of rubblecrop is present, consisting of buff weathering, very-fine- to fine-grained sandstone. Bed thickness is difficult to assess, but slabs in float include plane-parallel lamination and current ripple cross-lamination (Bouma $\mathrm{Tb}$ and $\mathrm{Tbc}$ ). Some bed surfaces in float include small three-dimensional ripple bedforms (Bouma Tc) and mudstone rip-up clast impressions. Many clast impressions are lined with orange weathering material that resembles sideritized mudstone.

\section{INTERPRETATION}

The suite of features recognized in sandstones at this location suggest deposition from waning flows capable of transporting platy rip-up clasts in addition to fine-grained sand. Plane-parallel lamination and current ripple cross-lamination suggest deposition from waning flows that included an initial upper flow-regime plane bed phase (Bouma Tb). Additional interpretation is not possible given extremely limited exposure.

\section{Station 07DL063 \\ DESCRIPTION}

Station 063 corresponds to a prominent east-northeast-trending tributary valley on the east side of the drainage (figs. 2 and 4). Approximately $35 \mathrm{~m}$ of thinly bedded sandstone and siltstone are exposed on the south wall of the valley and dip 46 degrees toward the southeast (fig. 15). Sandstone is light to medium gray weathering, medium to dark gray on fresh surfaces, very fine grained, and in beds ranging from a few millimeters to $20 \mathrm{~cm}$ thick. Most beds are less than $4 \mathrm{~cm}$ thick (fig. 16a). Siltstone is medium gray to brown weathering and present as thin papery partings separating sandstone beds and as thicker (up to $1 \mathrm{~cm}$ ) caps to sandstones. One or two beds of orange weathering calcareous siltstone up to $20 \mathrm{~cm}$ thick are present in the succession (fig. 16b). Beds are continuous and of uniform thickness laterally, giving the outcrop a monotonous appearance (fig. 16a). Most sandstone beds include a basal graded layer overlain by plane-parallel lamination which, in turn, either grades upward to siltstone or is sharply overlain by siltstone (figs. 16c and 16d). These lithologies and structures combine to form Bouma Tabd, Tab, Tbd, and Tb beds. No sole markings or trace fossils have been found in rocks at this location.

\section{INTERPRETATION}

Bed thickness and character combined with common partial Bouma sequences suggest deposition from dilute turbidity currents in an unconfined setting. The undisturbed condition of bedding suggests deposition below the oxygen minimum layer, possibly in a slope setting. The absence of clay and the overall silty-sandy character of this exposure are consistent with deposition in a shelf-edge proximal slope setting. This interpretation is consistent with the overall stratigraphic context of this exposure, with interpreted lower slope to basin-floor deposits down-section to the northwest and bioturbated upper slope to outer-shelf strata up-section to the southeast (described below).

\section{Station 07DL064 \\ DESCRIPTION}

Approximately $20 \mathrm{~m}$ of continuously exposed, thinly bedded, very-fine-grained sandstone and coarse siltstone are exposed along the east side of the main drainage, immediately downstream of a prominent westward bend in the river (figs. 2, 4, and 17). Beds dip 66 degrees toward the south near the north end of the exposure (fig. 18a) and dips shoal to 20 degrees or less toward the middle and south end of the exposure (fig. 18b). Some structural disruption is evident at the north end of the exposure in the form of either a tight fold (unlikely) or a bed-parallel thrust fault of minor displacement (likely; fig. 18c).

The ages of these rocks are constrained by stratigraphic position between Campanian age beds (late Campanian palynomorphs down-section at station 07DL061 and Campanian megafossils up-section at 01DL22 ).

Sandstones and siltstones are light gray weathering, medium-gray on fresh surfaces, in beds 1 to $15 \mathrm{~cm}$ thick. In the lower third of the exposure, thicker beds are grouped in bedsets within which beds are amalgamated or separated only by thin siltstone partings. Less thickness variation in bedding in the upper two-thirds of the ex- 
07DL63

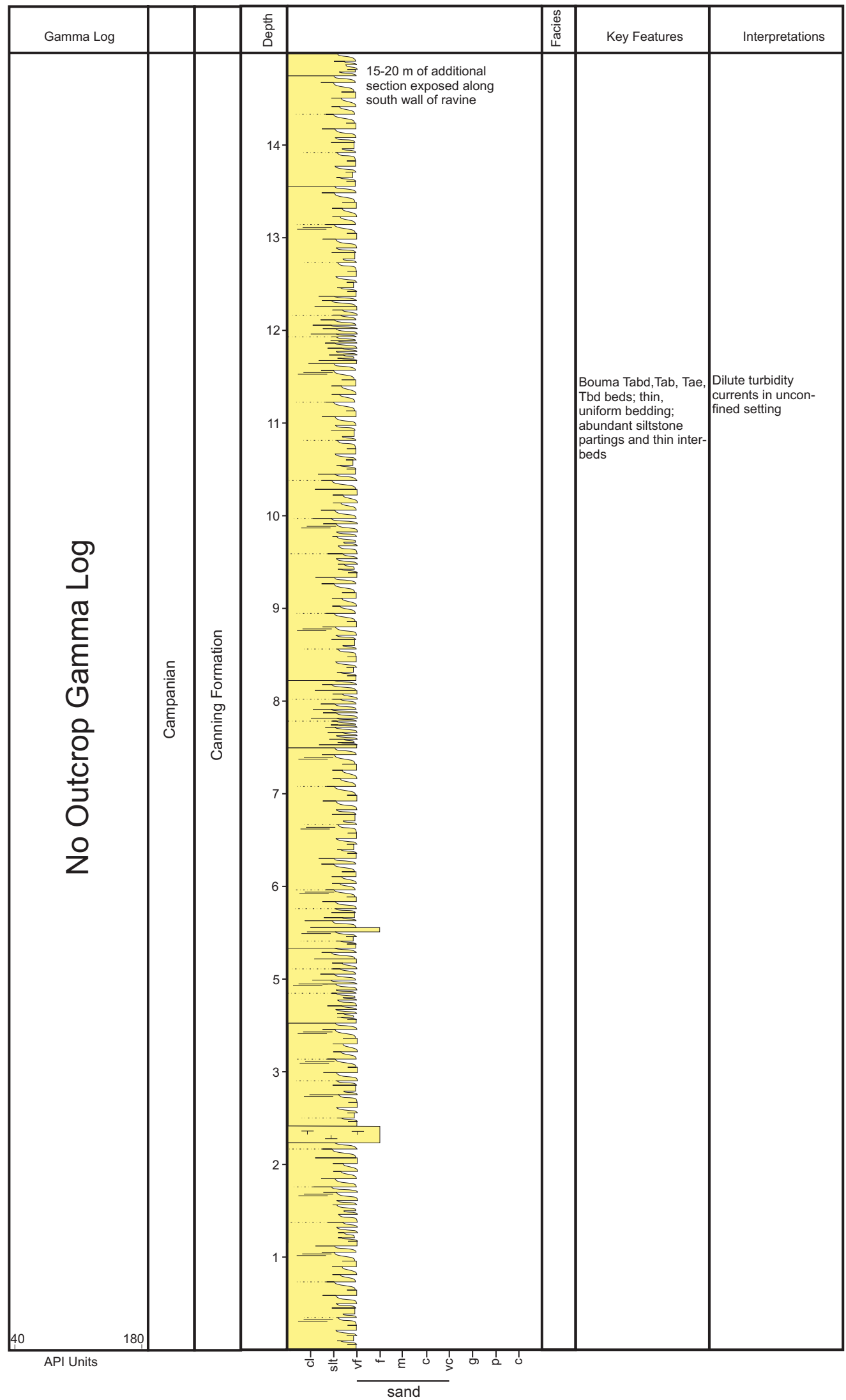

Figure 15. Measured stratigraphic section through Campanian age thin-bedded turbidites and associated hemipelagic siltstones of the Canning Formation at station 07DL063. See figure 5 (p. 92) for symbol key. 


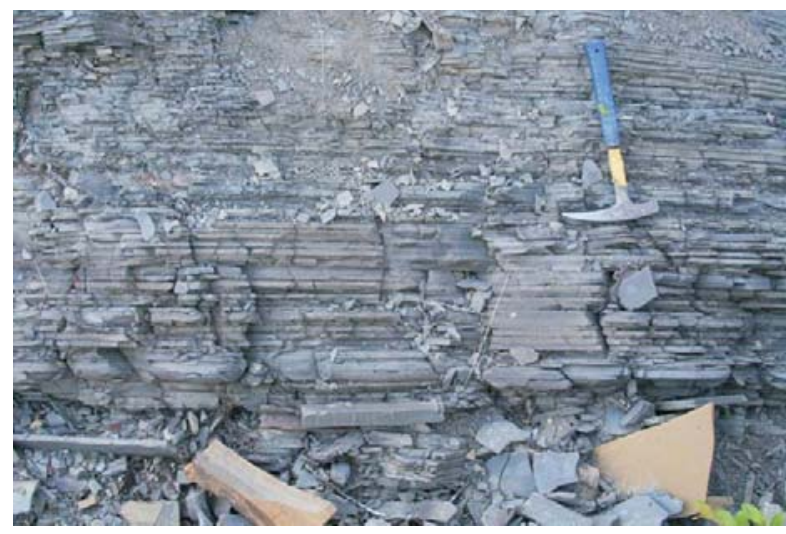

A.

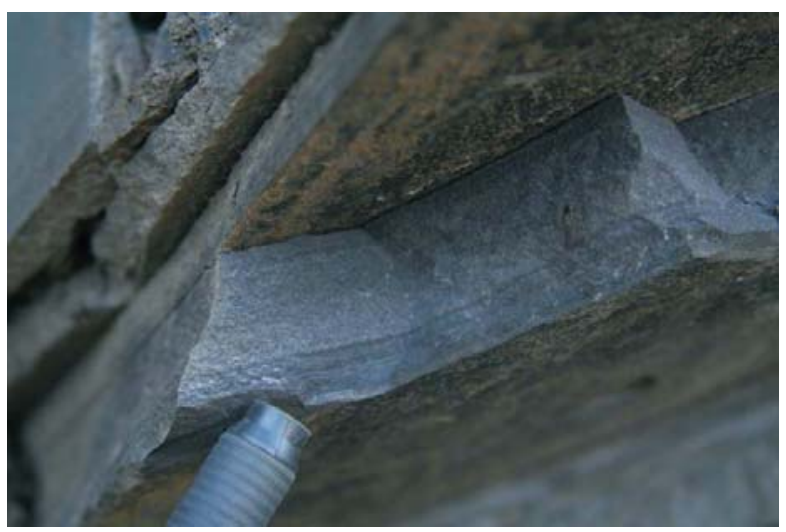

C.

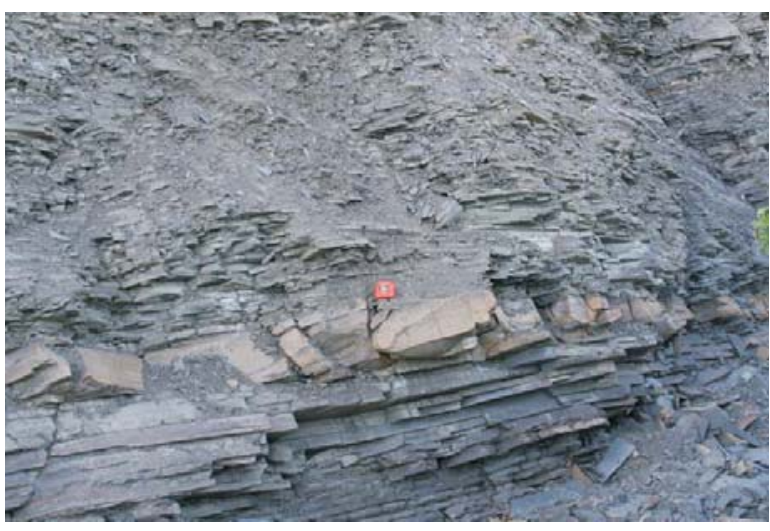

B.

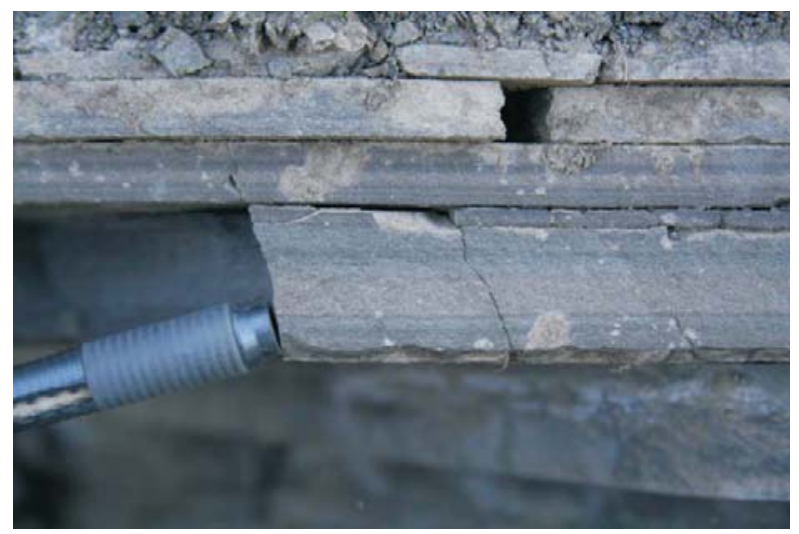

D.

Figure 16. Photographs of sedimentary features in Campanian turbidites of the Canning Formation at station $07 D L 063$. (A) Thin-bedded, very-fine-grained sandstone in the lower $4 \mathrm{~m}$ of the measured section. (B) Calcareous siltstone (orangebrown bed below tape measure) interbedded with very-fine-grained sandstone and siltstone. (C-D) Subtle Bouma Tabe and Tae sequences are visible.

posure gives the succession a more monotonous appearance. Beds are laterally continuous throughout the extent of their length in outcrop. Bioturbated beds (II3-4) occur interbedded with unbioturbated or sparsely bioturbated beds throughout the exposure, but the overall degree of bioturbation increases up-section toward the southeast (II3-4 throughout; fig. 18d). Scattered black chert pebbles floating in a sandstone matrix (fig. 18f) and remnants of ripple cross-lamination (fig. 18e) are common near the south end of the exposure. Small plant fragments litter the surface of many beds throughout the succession.

\section{INTERPRETATION}

Features described above suggest deposition in shallower water than strata exposed down-section (northwest), possibly in an upper slope to outer-shelf setting. The change in bioturbation from the base of the section toward the top can be explained by an increasing recurrence interval for episodic flow events up-section (associated with transgression?), thereby allowing more time between events for burrowing organisms to disrupt primary sedimentary structures. Available biostratigraphic data suggest correlation with shallower water strata of the Schrader Bluff Formation west of the Trans-Alaska pipeline corridor.

\section{Station 01DL021 \\ DESCRIPTION}

Station 021 is located on the north side of a prominent east-west-trending stretch of the river and includes approximately $6 \mathrm{~m}$ of sandstone (fig. 2 and 19). Sandstone is light greenish gray weathering, light gray on fresh surfaces, and fine grained. Beds range from 2 to $10 \mathrm{~cm}$ thick and are wavy, non-parallel, and laterally discontinuous in outcrop (fig. 20a). Discontinuous silty partings separate some beds and plant fragments are common on many 


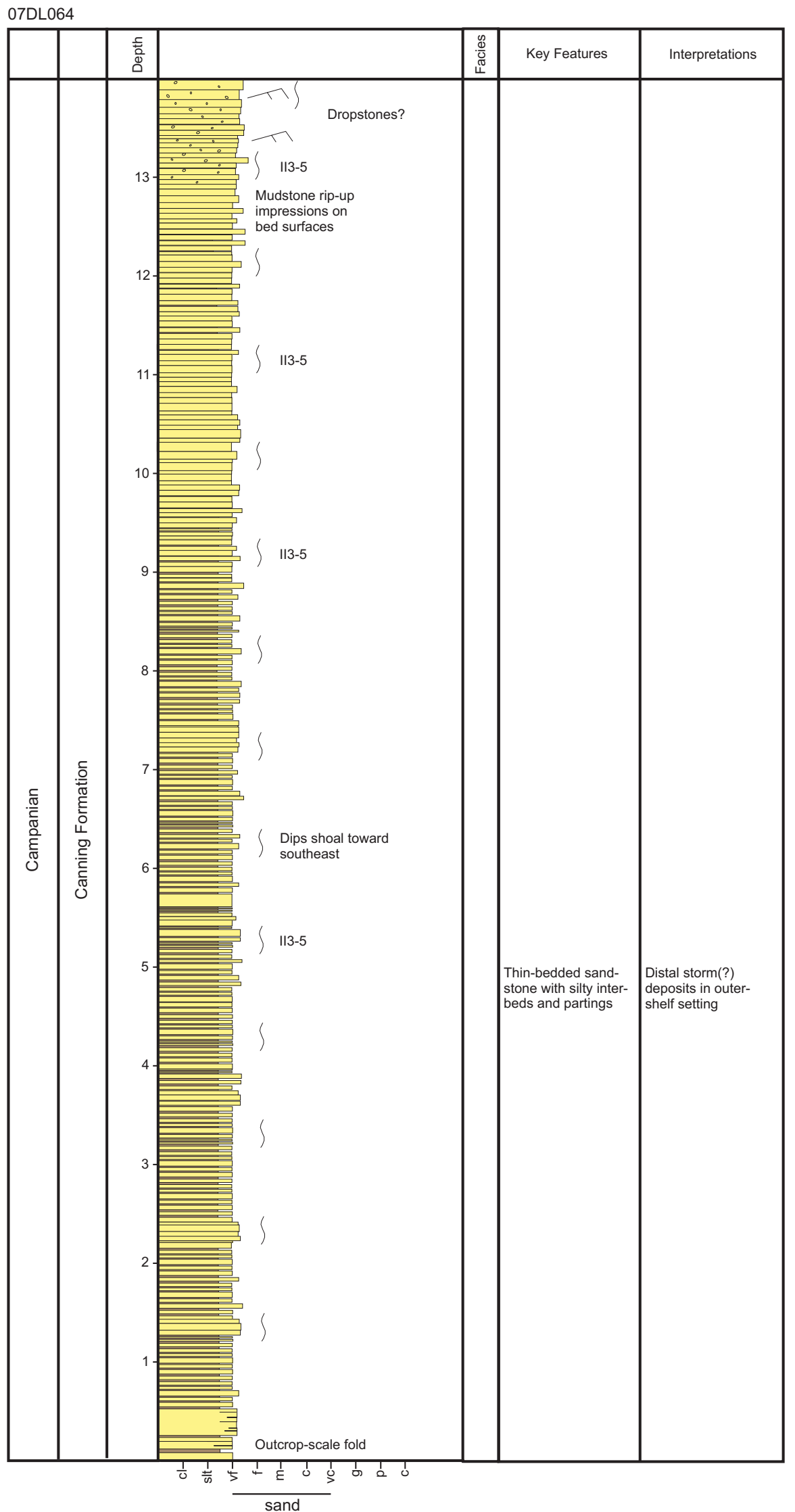

Figure 17. Measured stratigraphic section through probable Campanian age thin-bedded upper-slope to outer-shelf deposits transitional between the Canning and Schrader Bluff Formations. See figure 5 (p. 92) for symbol key. 


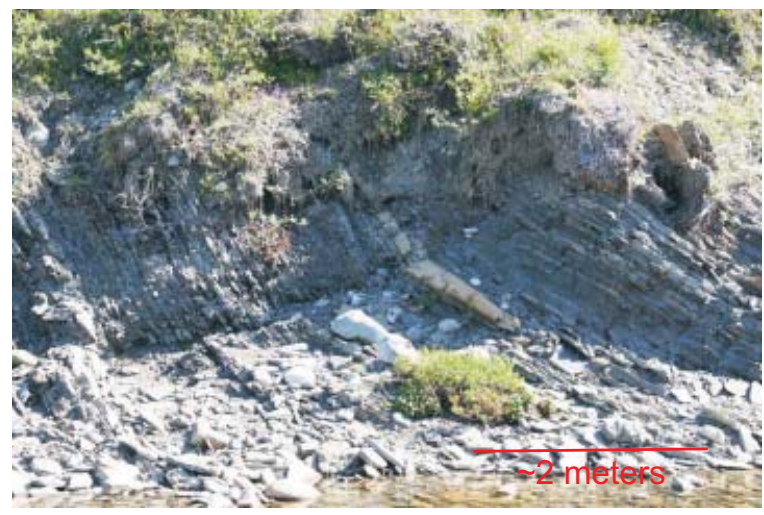

A.

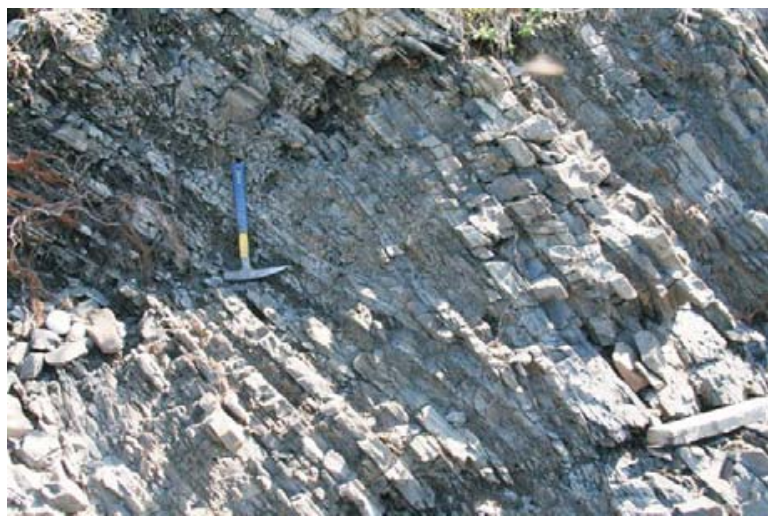

C.

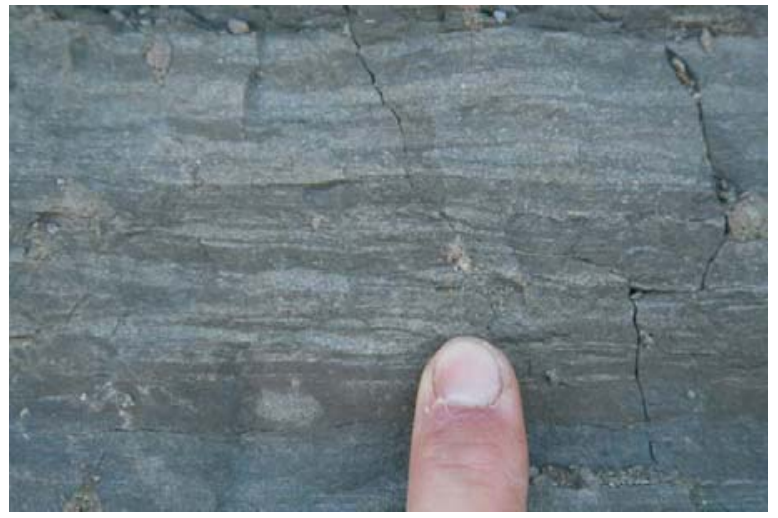

E.

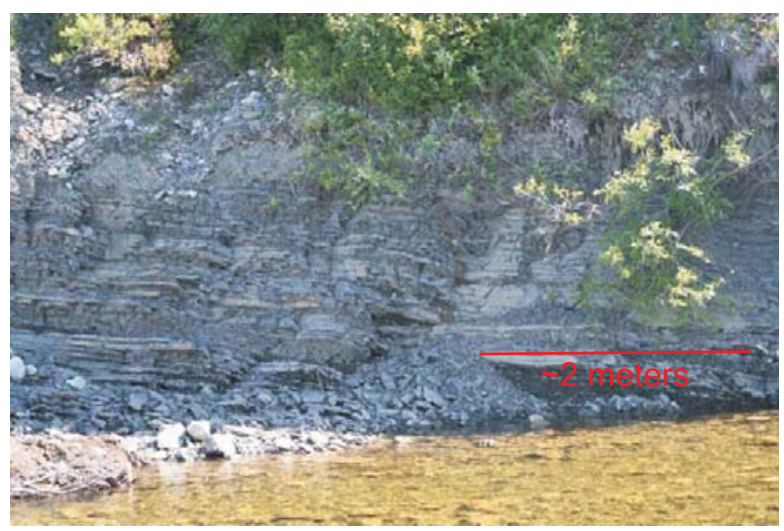

B.

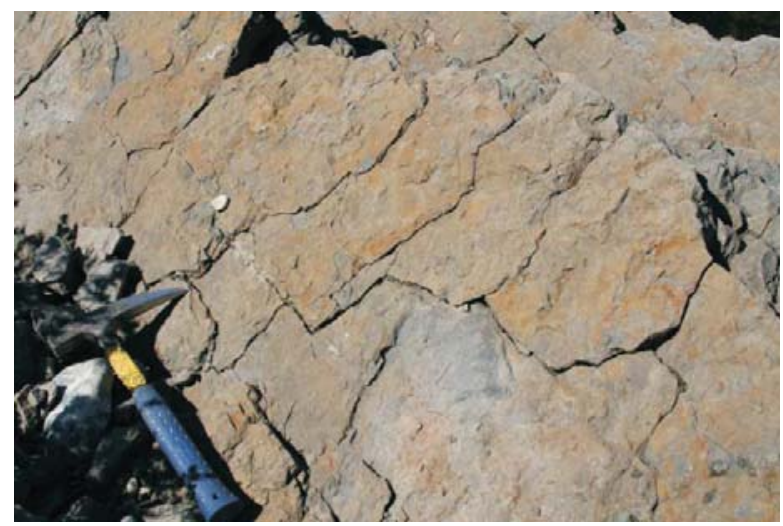

D.

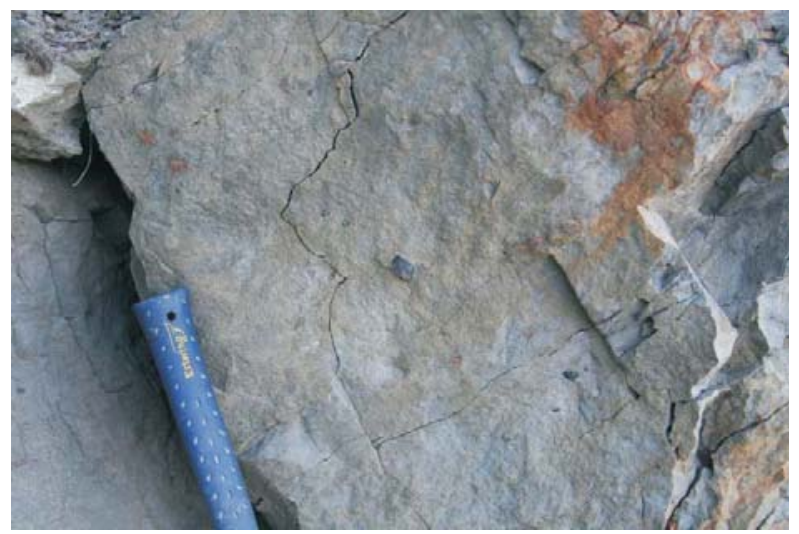

F.

Figure 18. Photographs of sedimentary features in probable Campanian strata transitional between the Canning and Schrader Bluff Formations at station 07DL063. (A) Thinly interbedded siltstone and very-fine-grained sandstone at the northwest end of the station (1-4 $\mathrm{m}$ in measured section shown in fig. 17) dipping up to 66 degrees toward the south. (B) Gently southdipping interbedded siltstone and very-fine-grained sandstone in the central part of the exposure (7-9 $\mathrm{m}$ in the measured section shown in fig. 17). (C) Bed-scale thrust(?) fault at $0.5 \mathrm{~m}$. (D) Bioturbated very-fine-grained sandstone at $13 \mathrm{~m}$. (E) Floating chert pebbles in sandstone at $13.5 \mathrm{~m}$. (F) Starved ripple cross-lamination in very-fine-grained sandstone at southeast end of exposure $(14 \mathrm{~m})$. 
01DL021

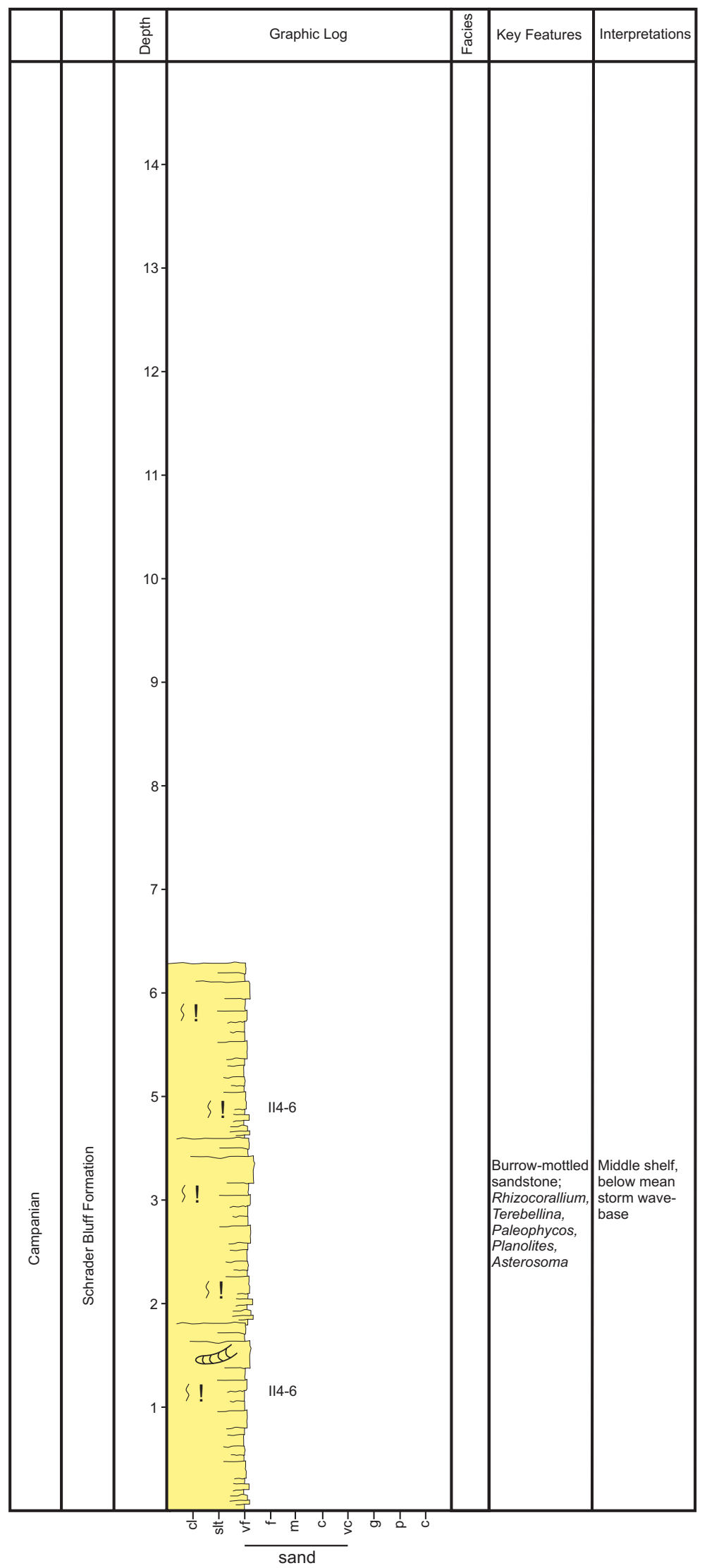

Figure 19. Measured stratigraphic section through Campanian age shelf deposits of the Schrader Bluff Formation at station 01DL021. See figure 5 (p. 92) for symbol key. 
bed surfaces (fig. 20b). Beds are burrow mottled (II4-6) and only isolated remnants of ripple cross-lamination are preserved. Trace fossils of the distal Cruziana ichnofacies are present, including Rhizocorallium, Planolites, Paleophycos, Schaubcylindrichnus, and Asterosoma (figs. 20c-e). At least one sandstone bed includes abundant small circular traces up to $1 \mathrm{~mm}$ in diameter filled with dark gray material that resembles Anconichnus (or Helminthopsis?). A single specimen of the bivalve Solecurtis? chapmani (wide ranging in time) was found in float.

\section{INTERPRETATION}

Moderate to highly bioturbated sandstone, the general lack of siltstone and shale, and a relatively diverse trace-fossil assemblage belonging to the Cruziana ichnofacies are suggestive of deposition in well-oxygenated water, possibly in a lower shoreface setting. An offshore shelf setting is possible and sand may have been transported offshore by fluvial flood-generated hyperpycnal flows (Mulder and Syvitski, 1995; Myrow and others, 2002) discharging from river mouths up depositional dip, or by storm-surge ebb flows (Swift and others, 1985). The succession could represent the distal part of a low-energy shoreface succession, which is consistent with a shelf setting below mean storm wave-base. Alternatively, the succession could record deposition in a shelf setting above storm wave-base, but in an area where the recurrence interval between major storms was long. Available biostratigraphic data suggest correlation with shallower water strata of the Schrader Bluff Formation west of the Trans-Alaska pipeline corridor.

\section{Station 022}

\section{DESCRIPTION}

Station 022 is located at the southeast end of the trend, on the southwest side of the drainage (figs. 2, and 22a). Approximately $142 \mathrm{~m}$ of discontinuously exposed siltstone and sandstone are present on a north-facing slope that corresponds to the north limb of a syncline (fig. 21). The exposure starts at river level and extends up-slope to the southwest (figs. 2 and 22b). Nondescript rubble extends from the top of the slope (fig. 2, top of measured section 01DL022) southward to the axis of the syncline. The succession described here does not include the rubble south of the measured section. Beds dip 10 degrees toward the south.

The age of this succession is constrained by early Maastrichtian to late Campanian palynomorphs collected from near the base (LePain, unpublished data) and by Campanian megafossils collected near the top (Mull, unpublished data). The succession is probably late Campanian.

The lower 13-16 m consists of thin-bedded, silty, very-fine-grained sandstone to coarse, sandy siltstone (fig. 22b). Silty sandstone is light gray weathering and medium gray on fresh surfaces. Beds are wavy and discontinuous, and range from $>1$ to $15 \mathrm{~cm}$ thick. Ferruginous ovoid-shaped concretions up to $2 \mathrm{~cm}$ in maximum diameter are common in float. Rocks have a bioturbated appearance (II3-4?) and curvilinear trace fossils are common on bed surfaces, and some pieces of float include Terebellina? (or Schaubcylindrichnus).

The lower 13-16 m extends up to a prominent break in slope, above which the slope is shallower and underlain by dark gray weathering siltstone that extends up-section to at least $50 \mathrm{~m}$ (figs. 21 and 22c). Few bedsets of red-brown to gray weathering, lower, very-fine-grained sandstone form inconspicuous resistant ledges up to 1 $\mathrm{m}$ thick within the siltstone (figs. 22d-e). Sandstones include pyritic(?) concretions up to $1 \mathrm{~cm}$ in diameter and have a crumbly, burrowed-mottled (II4-5) appearance. Trace fossils resembling Terebellina or Paleophycos are present locally.

The upper $67 \mathrm{~m}$ consists of discontinuously exposed sandstone. The lower $2.4 \mathrm{~m}$ (75.1 to $77.5 \mathrm{~m}$ on fig. 21) consists of light gray weathering, locally rusty-brown weathering, very-fine- to fine-grained sandstone. Bed thickness and geometry are difficult to determine due to uniform grain size and nearly uniform weathering character; beds have an irregular parting character and an overall appearance suggestive of a moderate degree of bioturbation (II3-4?; fig. 22f). Terebellina or Paleophycos are the only recognizable trace fossils. Scattered orange-brown weathering, concretion-like cemented sandstone masses up to $2 \mathrm{~cm}$ in diameter may be burrow-fills of unknown affinity. Isolated remnants of sparsely bioturbated low-angle convex-upward laminae are present locally.

Discontinuously exposed sandstone from $114 \mathrm{~m}$ to $142 \mathrm{~m}$ is light gray to buff weathering and upper very fine to fine grained. Grain size appears to coarsen slightly from the base to the top of this interval. Most of this interval appears moderately bioturbated (II3) with scattered sparsely bioturbated (II1-2) beds 5-15 cm thick (fig. 22g). Discrete trace fossils are not recognizable. Pyritic(?) concretions up to a few centimeters in diameter are common. Concave-up surfaces scattered throughout are suggestive of small- to moderate-scale trough cross-bedding. Wave-ripple bedforms (fig. 22h) and possible hummocky cross-stratification are present locally. A distinctive pitted or honeycombed weathering pattern characterizes discrete intervals. The origin of this weathering pattern is unknown - it may be the result of a bioturbation fabric. Sparsely bioturbated plane-parallel lamination is common in the upper $8 \mathrm{~m}$ of the exposure (fig. 22i). Float at the top of the exposure includes impressions of an articulated pelecypod that came to rest with valves wide open. 


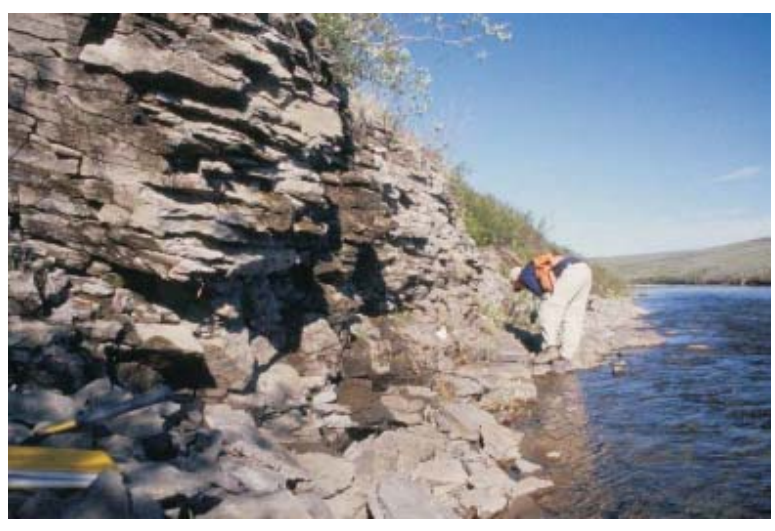

A.

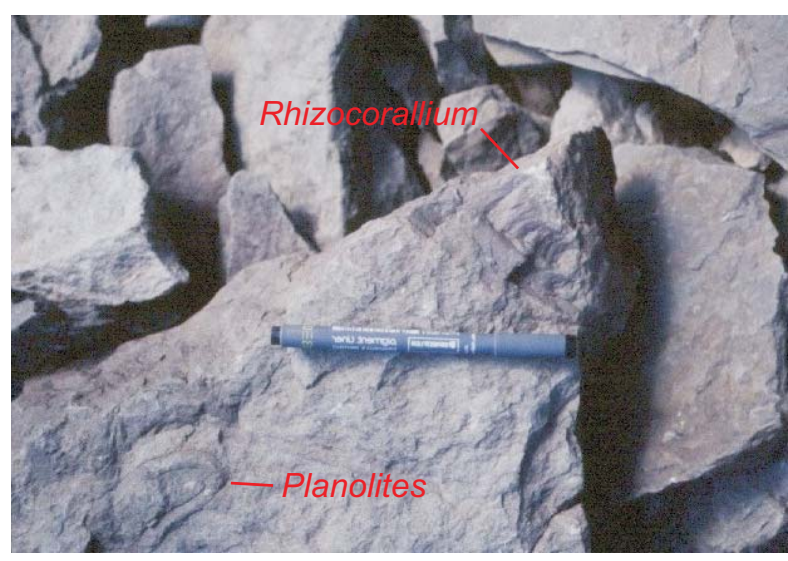

C.

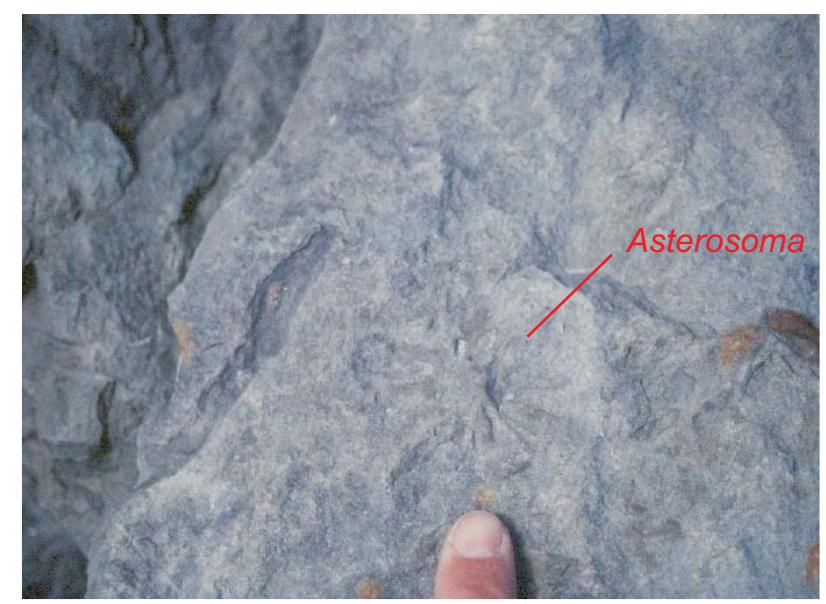

E.

Figure 20. Photographs of sedimentary features in Campanian age shelf deposits of the Schrader Bluff Formation at station 01DL021. (A) Thin, wavy bedded, bioturbated, very-fine-grained sandstone from 0-3 m. (B) Plant fragments on parting surface in bioturbated very-fine-grained sandstone at $3 \mathrm{~m}$. (C) Planolites and part of a Rhizocorallium trace at $1.6 \mathrm{~m}$. (D) Schaubcylindrichnus burrows in very-fine-grained sandstone at $3 \mathrm{~m}$. (E) Asterosoma trace in argillaceous very-finegrained sandstone at $2.5 \mathrm{~m}$.

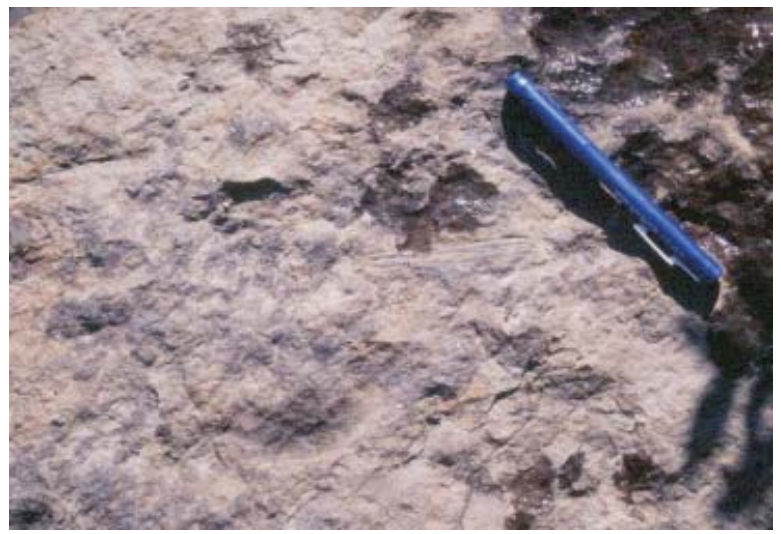

B.

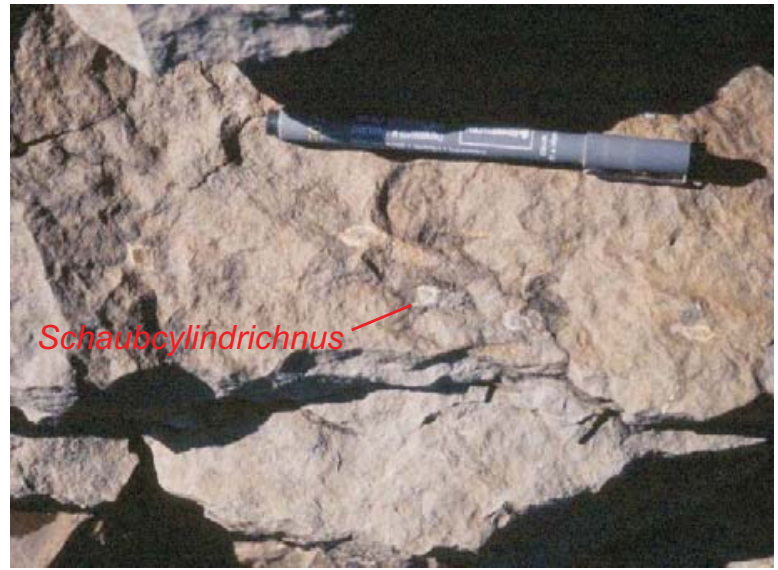

D. 


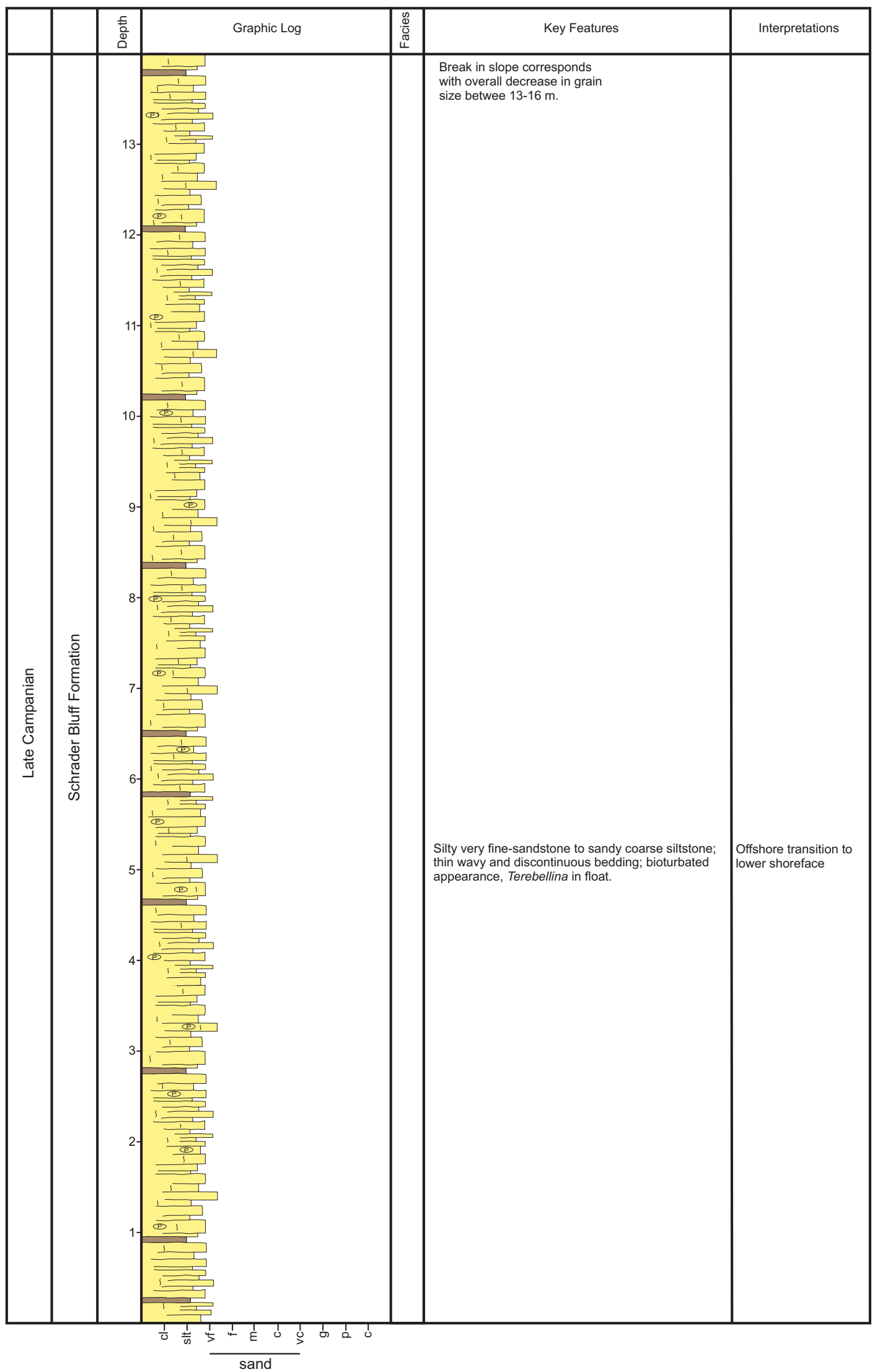

Figure 21. Measured stratigraphic section through probable late Campanian offshore, offshore transition, and shoreface/foreshore deposits of the Schrader Bluff Formation at station 01DL022. See figure 5 (p. 92) for symbol key. 
01DL022

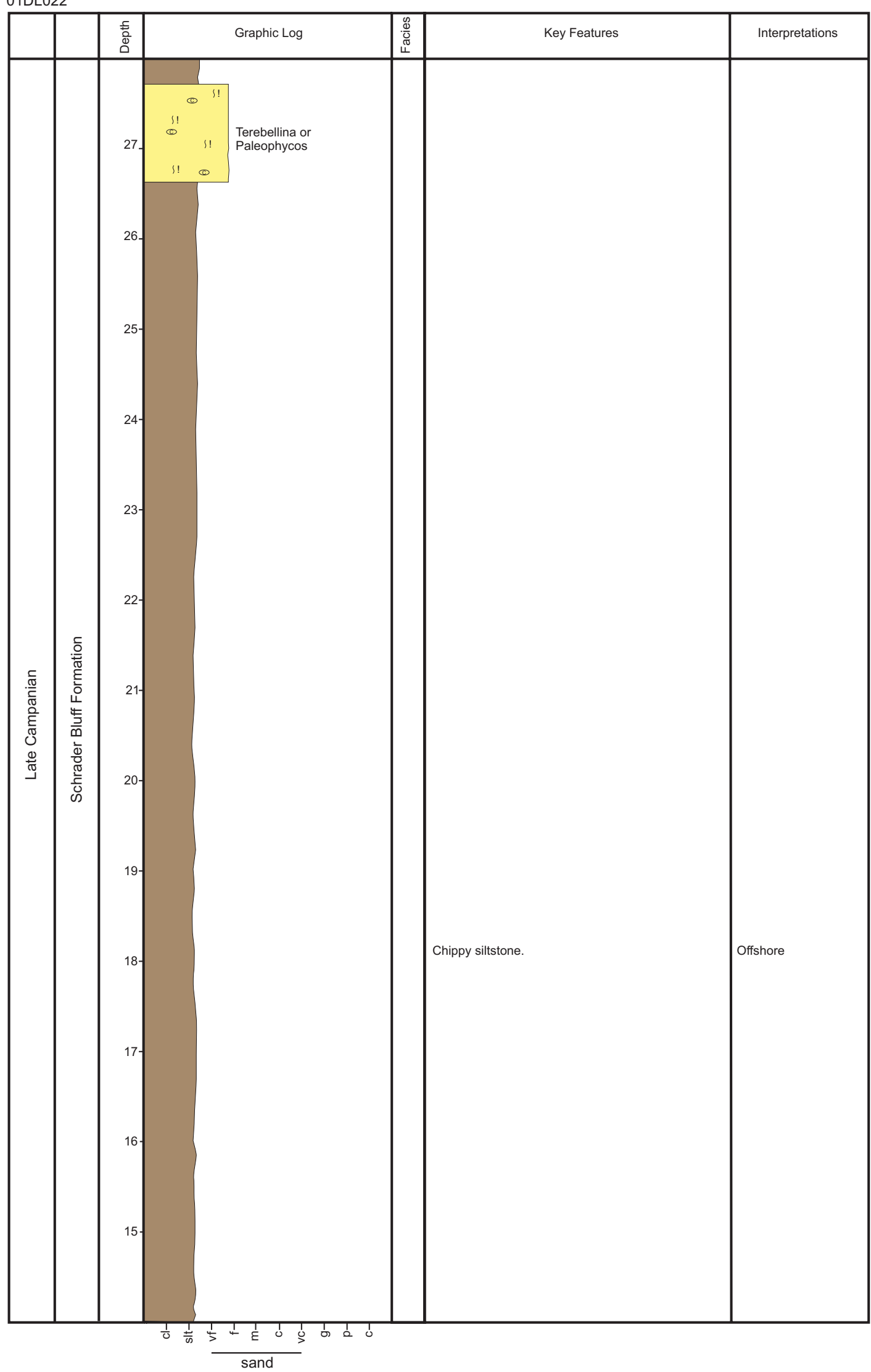

Figure 21. (continued) Measured stratigraphic section through probable late Campanian offshore, offshore transition, and shoreface/foreshore deposits of the Schrader Bluff Formation at station 01DL022. See figure 5 (p. 92) for symbol key. 


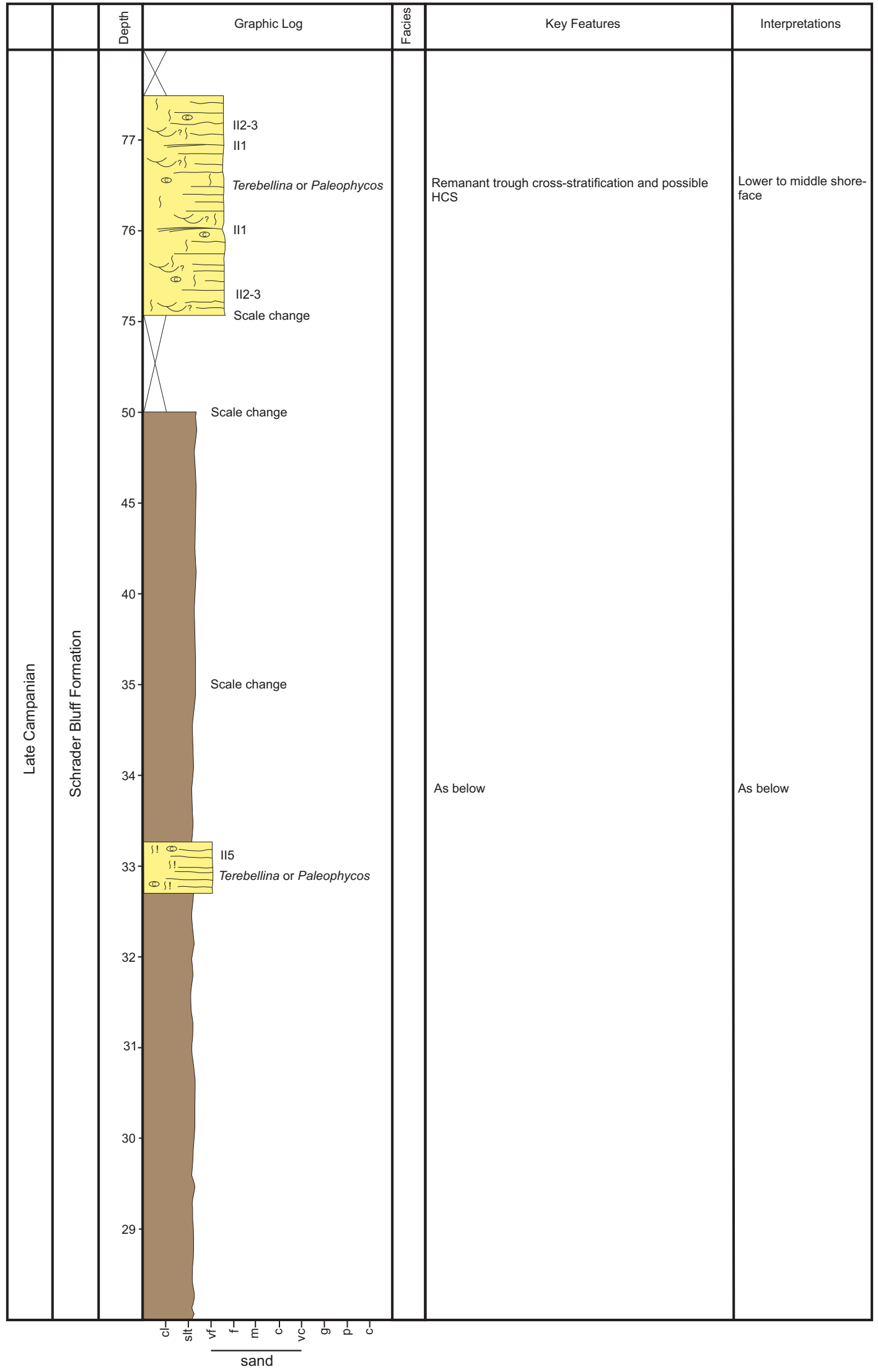

Figure 21. (continued) Measured stratigraphic section through probable late Campanian offshore, offshore transition, and shoreface/foreshore deposits of the Schrader Bluff Formation at station 01DL022. See figure 5 (p. 92) for symbol key. 
01DL022

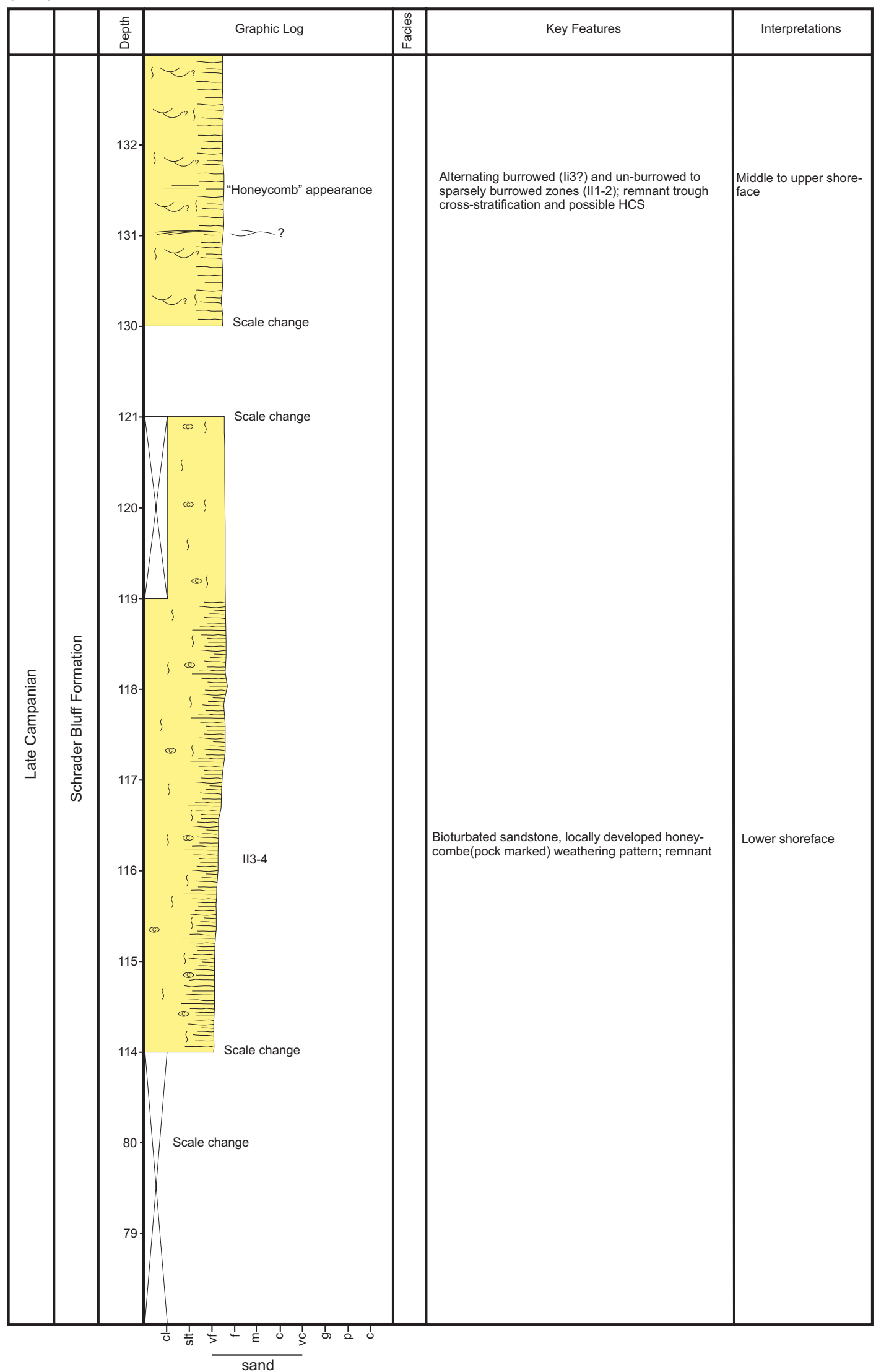

Figure 21. (continued) Measured stratigraphic section through probable late Campanian offshore, offshore transition, and shoreface/foreshore deposits of the Schrader Bluff Formation at station 01DL022. See figure 5 (p. 92) for symbol key. 


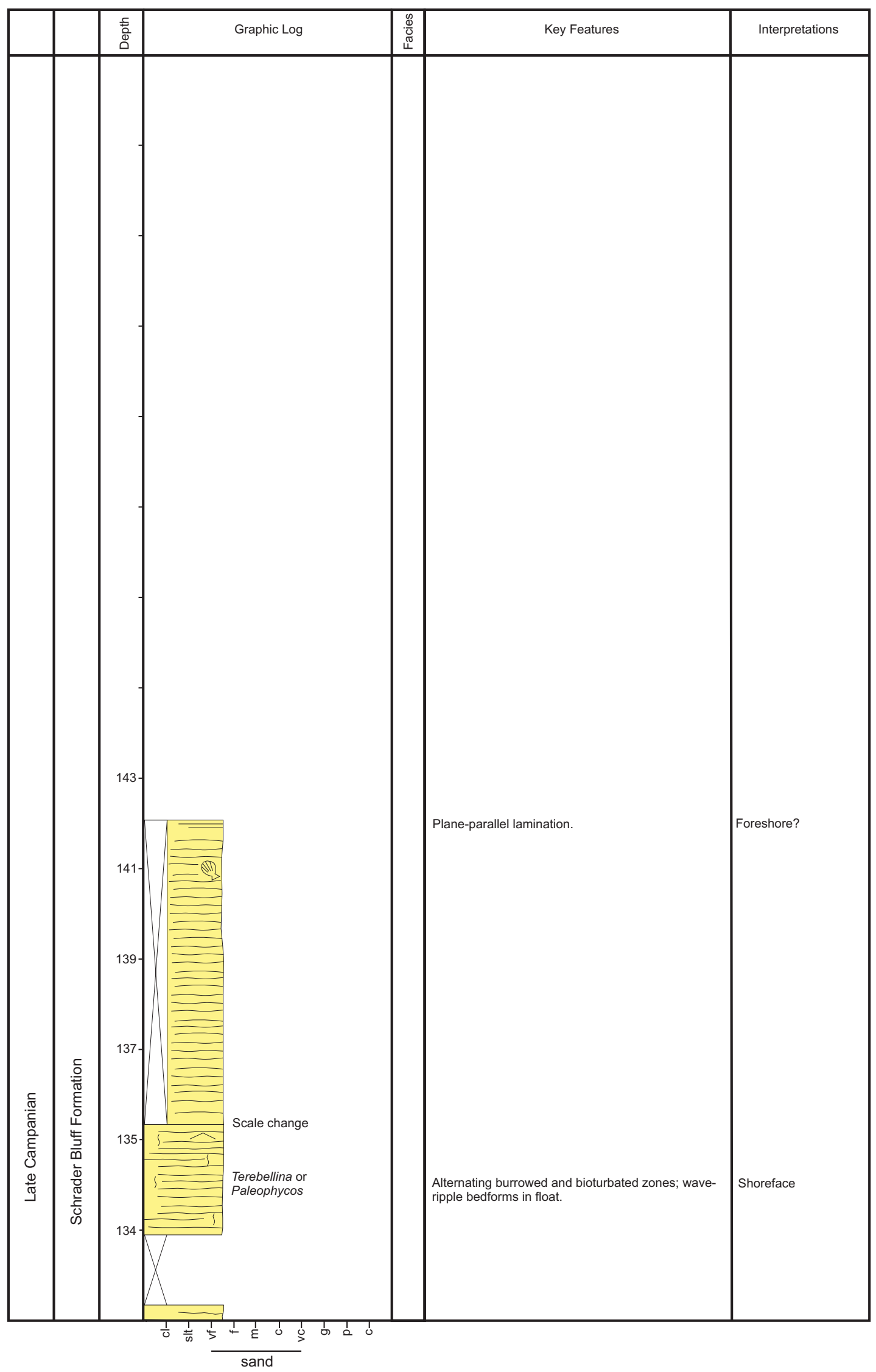

Figure 21. (continued) Measured stratigraphic section through probable late Campanian offshore, offshore transition, and shoreface/foreshore deposits of the Schrader Bluff Formation at station 01DL022. See figure 5 (p. 92) for symbol key. 


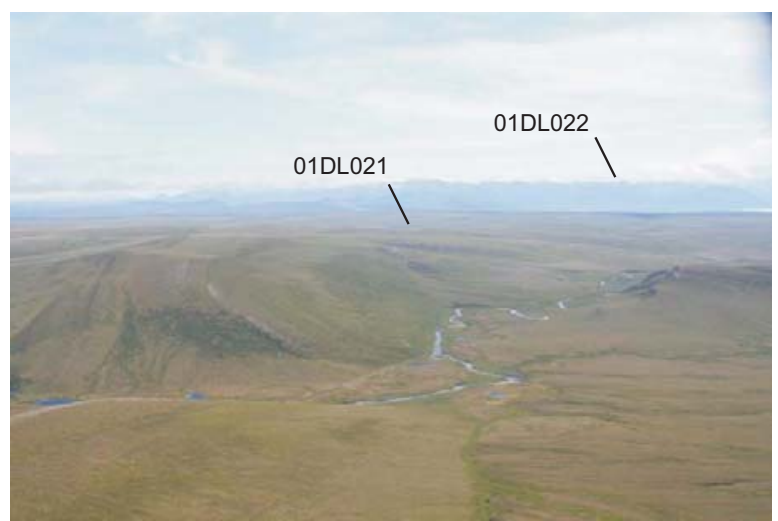

A.

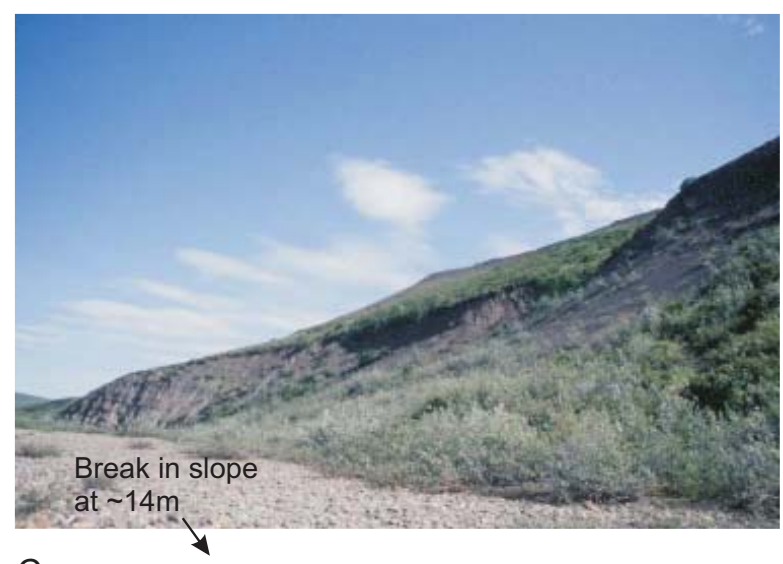

C.

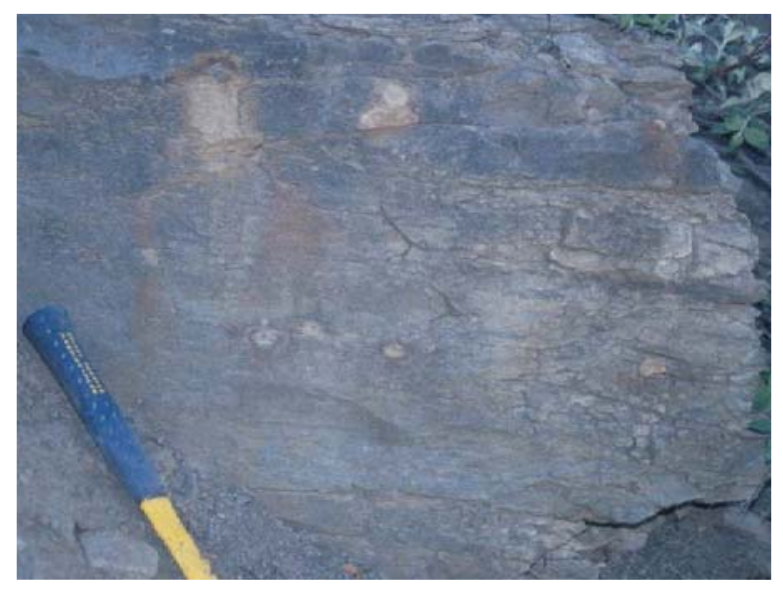

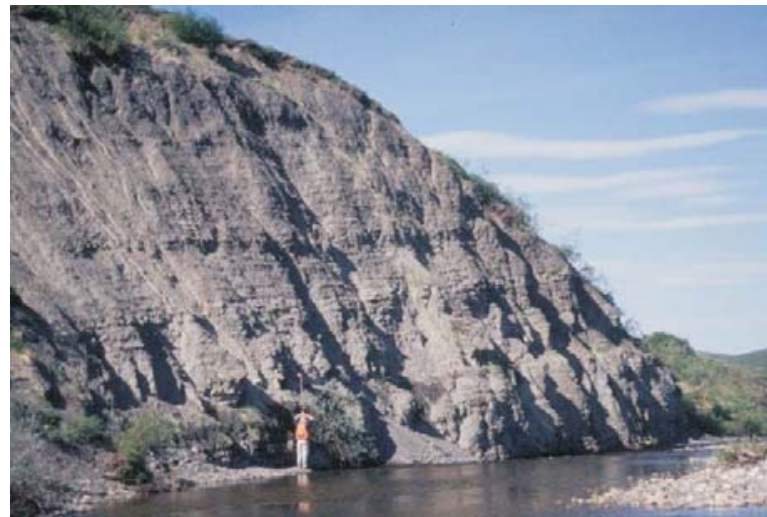

B.

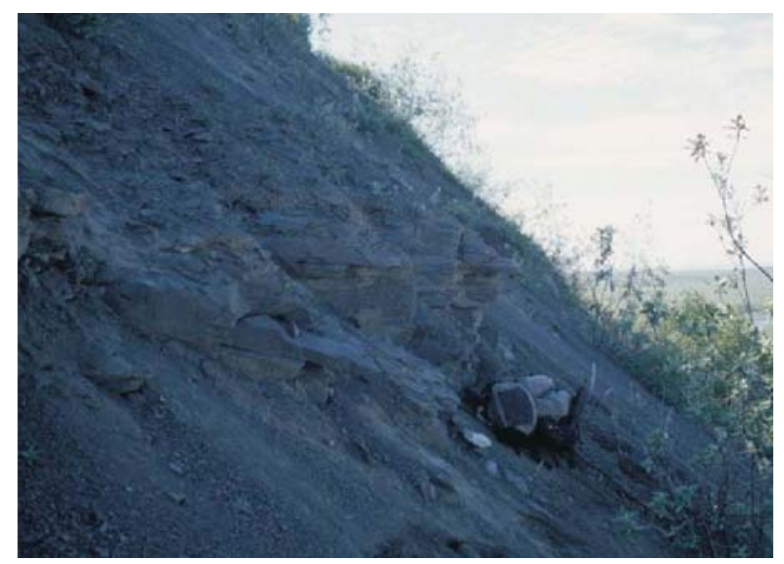

D.

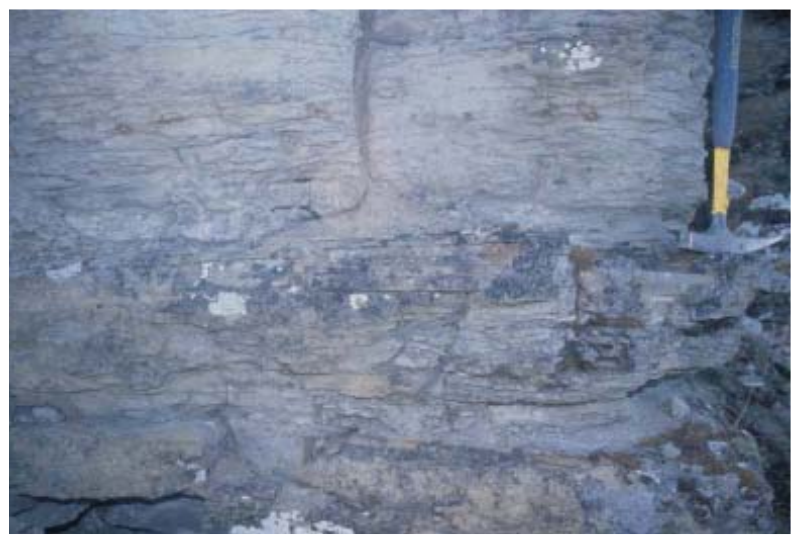

F.

E.

Figure 22 (A-F). Photographs of sedimentary features in probable late Campanian offshore, offshore transition, and shoreface/ foreshore deposits of the Schrader Bluff Formation at station 01DL022. (A) Aerial view toward the east showing station 01DL022 near the right edge of the photograph. Station 01DL021 is just beyond the left edge of the image. (B) View toward the west showing thinly-bedded siltstone and very-fine-grained sandstone in the lower 13-16 m of the exposure. Staff above the geologist's head is $1.5 \mathrm{~m}$ long. (C) View toward the southeast showing the break in slope (arrow) corresponding to the contact between interbedded siltstone and sandstone in the lower 14-16 m of the exposure and the overlying siltstone succession. ( $D-E)$ Resistant ledge of bioturbated very-fine-grained sandstone with centimeter-scale pyritic concretions between 26 and $34 \mathrm{~m}$. These sand bodies represented storm deposits in a proximal offshore setting. (F) Moderately bioturbated(?) very-fine- to fine-grained sandstone between 114 and $119 \mathrm{~m}$. 


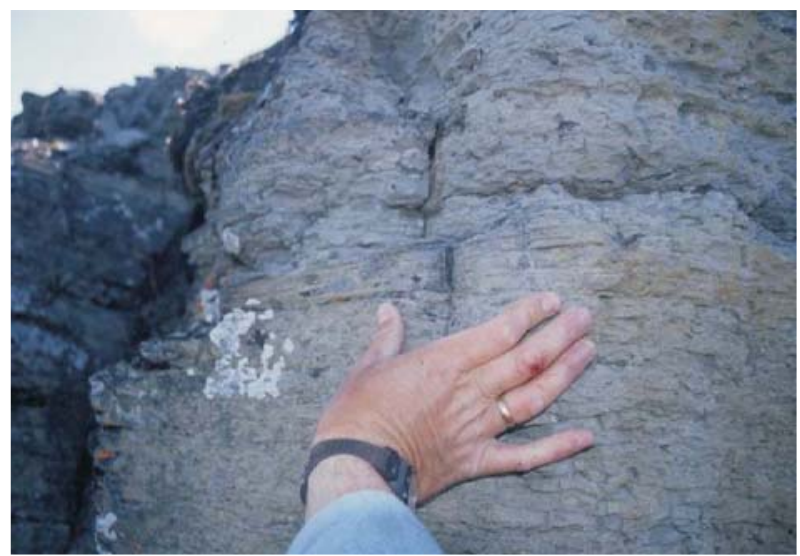

G.

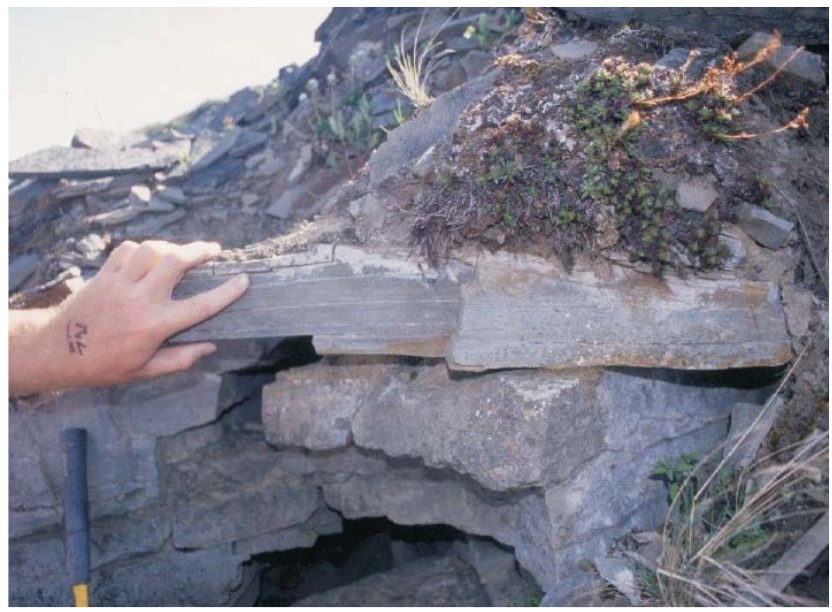

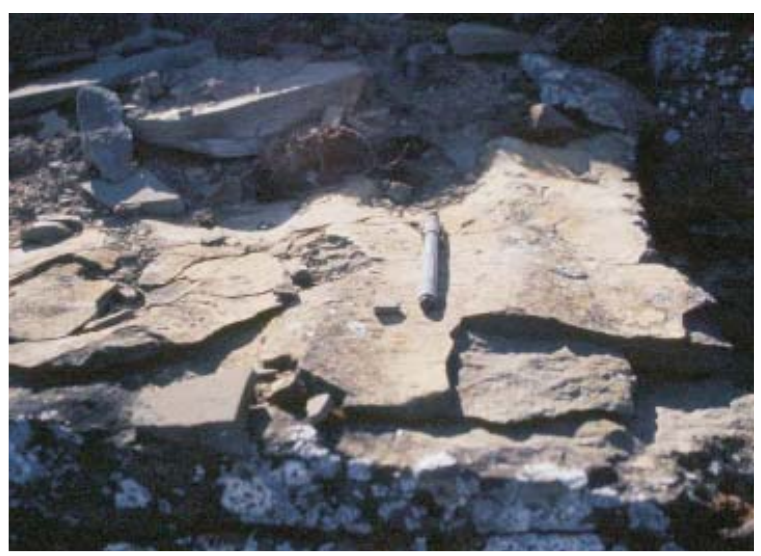

$\mathrm{H}$.

Figure 22 (G-I). Photographs of sedimentary features in probable late Campanian offshore, offshore transition, and shoreface/foreshore deposits of the Schrader Bluff Formation at station 01DL022. (G) Sparsely to moderately bioturbated finegrained sandstone at $119 \mathrm{~m}$. (H) Symmetric to slightly asymmetric two-dimensional wave ripple bedforms preserved on the surface of a sandstone bed at $135 \mathrm{~m}$. (I) Plane-parallel to slightly wavy parting (parting along faintly visible laminae) in fine-grained sandstone at $134 \mathrm{~m}$ interpreted as foreshore deposits.

I.

\section{INTERPRETATION}

The succession at station 22 is interpreted to record deposition as a series of stacked low-energy shoreface successions. The lower 13-16 m are interpreted as offshore transition to lower shoreface deposits. The prominent break in slope at the top of this package corresponds to a flooding surface and parasequence boundary. The overlying siltstone-sandstone package from $14 \mathrm{~m}$ to $77.5 \mathrm{~m}$ is interpreted as the next higher offshore-shoreface parasequence in the stack. Sandstones from $114 \mathrm{~m}$ to the top of the exposure represent the proximal part of the highest offshore-shoreface parasequence in the exposure; offshore shelf (seaward of shoreface) to offshore-transition (transition zone between shoreface and offshore shelf) strata correspond to the covered interval forming the basal $36 \mathrm{~m}$ of this parasequence. Plane-parallel laminae near the top of the succession are interpreted as foreshore deposits. It is possible that the upper parasequence as defined here actually includes two parasequences with a flooding surface at $121 \mathrm{~m}$. The succession of parasequences documented defines a progradational stacking pattern. Available biostratigraphic data suggest correlation with shallower water strata of the Schrader Bluff Formation west of the Trans-Alaska pipeline corridor.

\section{SUMMARY}

Work by DGGS during the 2001, 2002, and 2007 field seasons has documented deep-water through shoreline deposits along an unnamed drainage between the Sagavanirktok and Ivishak rivers. Despite numerous examples of outcrop-scale structural complications and long covered intervals along this trend, these exposures are interpreted to record an approximately 2,460-meter-thick, relatively unbroken succession of lower Turonian deep-water (station 07DL045) through Campanian shallow-water (station 01DL22) deposits (fig. 23). Exposures along this trend correspond to relatively resistant sandstone and tuff lithologies, and shaly lithologies are inferred to underlie the 


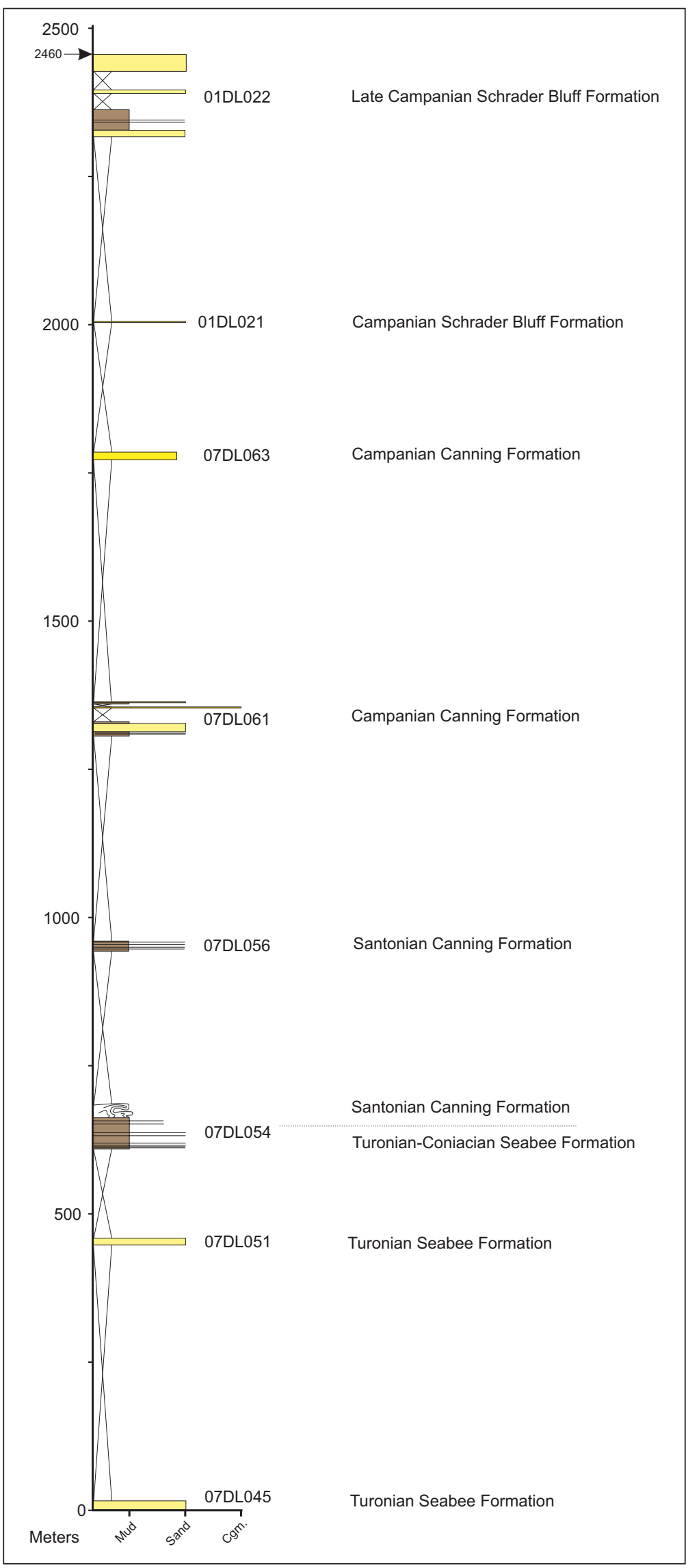

Figure 23. Composite stratigraphic section showing Upper Cretaceous strata constructed from stations 07DL045 through 01DL022. See figure 5 ( p. 92) for symbol key. 
long covered intervals. Our outcrop work suggests that the lower 1,300 m of section (stations 045 through station 061) records deposition in deep-water settings ranging from basin floor to lower slope settings. The limited lateral and vertical extent of these exposures precludes detailed interpretations, but available outcrop information allows tentative interpretations of deep-water architectural elements, including sandstone lobes, channel levee, and channel elements. Approximately $800 \mathrm{~m}$ of slope facies lies between stations 061 and 064 , and approximately $350 \mathrm{~m}$ of outer shelf through shoreface and possible foreshore strata are interpreted at the southeast end of the trend.

\section{ACKNOWLEDGMENTS}

Gil Mull recognized the significance of the succession along Sagashak Creek long ago and freely shared his knowledge of the area. Paige Delaney created fig. 2. We thank you both.

\section{REFERENCES}

Brosgé, W.P., and Whittington, C.L., 1966, Geology of the Umiat-Maybe Creek Region, Alaska: U.S. Geological Survey Professional Paper 303-H, 637 p.

Droser, M.L., and Bottjer, D.J., 1986, A semiquantitative field classification of ichnofabric: Journal of Sedimentary Petrology, v. 56, p. 558-559.

Houseknecht, D.W., and Schenk, C.J., 2001, Depositional sequences and facies in the Torok Formation, National Petroleum Reserve-Alaska (NPRA), in Houseknecht, D.W., ed., NPRA Core Workshop Petroleum Plays and Systems in the National Petroleum Reserve-Alaska: SEPM Core Workshop No. 21, p. 179-199.

_2004, Sedimentology and sequence stratigraphy of the Cretaceous Nanushuk, Seabee, and Tuluvak Formations exposed on Umiat Mountain, north-central Alaska, in U.S. Geological Survey in Alaska, 2004: U.S. Geological Survey Professional Paper 1709-B, 19 p.

Molenaar, C.M., Bird, K.J., and Collett, T.S., 1986, Regional correlation sections across the North Slope of Alaska: U.S. Geological Survey Miscellaneous Field Studies Map MF-1907, 1 sheet.

Molenaar, C.M., Bird, K.J., and Kirk, A.R., 1987, Cretaceous and Tertiary stratigraphy of northeastern Alaska, in Tailleur, I., and Weimer, P., eds., Alaskan North Slope Geology: Pacific Section, SEPM, vol. 1, p. 513-528.

Mulder, T., and Syvitski, J.P.M., 1995, Turbidity currents generated at river mouths during exceptional discharges at the world oceans: The Journal of Geology, v. 103, p. 285-299.

Mull, C.G., 1989, Generalized geologic map of the Brooks Range and Arctic Slope, Northern Alaska, scale 1 inch = 45 miles, in Mull, C.G., and Adams, K.E., eds., Bedrock geology of the eastern Koyukuk Basin, central Brooks Range, and east-central Arctic Slope along the Dalton Highway, Yukon River to Prudhoe Bay, Alaska: Alaska Division of Geological \& Geophyical Surveys Guidebook 7 vol. 1, 309 p.

Mull, C.G., and Harris, E.E., 1989, Dalton Highway road log from Chandalar Shelf (Mile 237.1 to Prudhoe Bay (Mile 414), in Mull, C.G., and Adams, K.E., eds., Bedrock geology of the eastern Koyukuk Basin, central Brooks Range, and eastcentral Arctic Slope along the Dalton Highway, Yukon River to Prudhoe Bay, Alaska: Alaska Division of Geological \& Geophysical Surveys Guidebook 7 vol. 1, p. 101-132.

Mutti, E., and Normark, W.R., 1987, Comparing examples of modern and ancient turbidite systems: Problems and concepts, in Legget, J.K., and Zuffa, G.G., eds., Marine Clastic Sedimentology: London, Graham and Trotman, p. 1-38.

Mutti, E., and Ricci Lucchi, F., 1978, Turbidites: International Geology Review, v. 20, p. 127-166.

Myrow, P.M., Fischer, W., and Goodge, J.W., 2002, Wave-modified turbidites; Combined-flow shoreline and shelf deposits, Cambrian, Antarctica: Journal of Sedimentary Research, v. 72, p. 641-656.

Pickering, K., Stow, D., Watson, M., and Hiscott, R., 1986, Deep-water facies, processes and models; A review and classification scheme for modern and ancient sediments: Earth-Science Reviews, v. 23, p. 75-174.

Spicer, R.A., Parrish, J.T., and Grant, P.R., 1992, Evolution of vegetation and coal-forming environment in the late Cretaceous of the North Slope of Alaska, in McCabe, P.J., and Parrish, J.T., eds., Controls on the Distribution and Quality of Cretaceous Coals: Geological Society of America Special Paper 267, p. 177-192.

Swift, D.P.J., Niedoroda, A.W., and Brown, R.J., 1985, Fluid and sediment transport dynamics on continental shelves, in Tillman, R.W., Swift, D.P.J, and Walker, R.G., eds., Shelf Sands and Sandstone Reservoirs: SEPM Short Course No. 13, p. 47-133.

Weimer, P., and Slatt, R.M., 2007, Introduction to the Petroleum Geology of Deepwater Setting: AAPG Studies in Geology No. 57, AAPG/Datapages Discovery Series 8, 1 CD.

Whittington, C.L., 1956, Revised stratigraphic nomenclature of Colville group, in Gryc, G. and others, Mesozoic sequence in Colville River region, northern Alaska: American Association of Petroleum Geologists Bulletin, v. 40 , p. 244-253. 
This page has intentionally been left blank. 